\title{
Hanford Site Solid Waste Landfill Interim Closure Plan
}

Date Published

May 1996

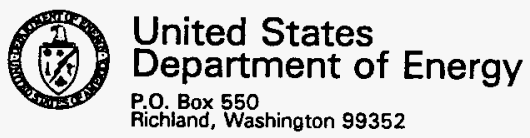

Approved for Public Release 
TRADEMAFK DISclaMmer

Reference herein to any epecific commercial product, process, or service by trede neme, trademark, manufacturer, of otherwise, does not nocesserily constitute or imply its endorsement, recommendetion, or fevoring by the United

Stetes Government or any agency thereof or its contrectors or subcontractors.

This report has been reproduced from the best aveilable copy. Aveilable in peper copy and microficho.

Available to the U.S. Department of Energy

and its contractors from

U.S. Department of Energy

Office of Scientific and Tochnical Information (OST)

P.O. Box 62

Oak Ridge, TN 37831

(615) 576-8401

Aveileble to the public from the U.S. Department of Commerce National Tochnical Information Sarvico (NTIS)

5285 Port Royel Roed

Springfield, VA 22161

(703) $487-4650$

Firtad in the Urited Statee of Americe

DISCLM-5.CHP (8-95) 
STATE ENVIRONMENTAL POLICY ACT

ENVIRONMENTAL CHECKLIST FORM

FOR THE

INTERIM CLOSURE OF THE

SOLID WASTE LANDFILL

January 2, 1995

WASHINGTON ADMINISTRATIVE CODE

ENVIRONMENTAL CHECKLIST FORMS

[WAC 197-11-960] 


\section{STATE ENVIRONMENTAL POLICY ACT ENVIRONMENTAL CHECKLIST}

\section{A. BACKGROUND}

1. Name of proposed project, if applicable:

Interim closure of the Hanford Site Solid Waste Landfill (SWL).

Information contained in this checklist applies only to the SWL.

2. Names of applicants:

U.S. Department of Energy-Rich? and Operations (DOE-RL), ICF Kaiser Hanford (ICF-KH), and Westinghouse Hanford Company (WHC)

3. Address and phone number of applicants and contact persons:

Director

Environmental Restoration Division

U.S. Department of Energy

Richl and Operations office

P. 0 . Box 550

Richland, Washington 99352

(509) -376-5441
Manager

Facilities \& Site Services

ICF Kaiser Hanford Company

P. 0. Box 888

Richland, Washington 99352

(509) $-376-7053$

4. Date checklist prepared:

December 4, 1995

5. Agency requesting checkl ist:

State of Washington

Department of Ecology

Mail Stop PV-11

Olympia, Washington 98504-8711

6. Proposed timing or schedule (including phasing, if applicable):

Closure of the SWL has been requested by Washington State Department of Ecology. Interim closure activities are planned to be initiated

by March 31, 1996. The interim closure and postclosure activities

will be determined at the Data Quality objectives (DQO) process.

The postclosure care period is expected to be at least 20 years.

7. Do you have any plans for future additions, expansion, or further activity related to or connected with this proposal? If yes, explain.

No. 
8. List any environmental information you know about that has been prepared, or will be prepared, directly related to this proposal.

This State Environmental Policy Act (SEPA) Checklist is being submitted to the Washington State Department of Ecology (Ecology) concurrently with the interim closure for the SWL.

9. Do you know whether applications are pending for government approvals of other proposals directly affecting the property covered by your proposal? If yes, explain.

No. The permit for operations of the SWL was denied by Ecology.

10. List any government approvals or permits that will be needed for your proposal, if known.

Ecology will approve the SWL closure and postclosure plan and the design of the interim cover. The closure and postclosure activities will be defined during the DQO process. No other government permits are known to be required at this time.

11. Give a brief, complete description of your proposal, including the proposed uses and the size of the project and site. There are several questions later in this checklist that ask you to describe certain aspects of your proposal. You do not need to repeat those answers on this page.

This project pertains to the interim closure plan for the SWL. The SWL is a municipal-type solid waste and asbestos landfill. The SWL occupies approximately 65 acres.

The proposed project strategy is to close the site as a landfill in accordance with Washington Administrative Code (WAC) 173-304$407(3)$ (a) on December 31,1995 . All existing waste will be left in place, and a interim cover will be constructed over the entire site.

12. Location of the proposal. Give sufficient information for a person to understand the precise location of your proposed project, including a street address, if any, and section, township, and range, if known. If a proposal would occur over a range of area, provide the range or boundaries of the site(s). Provide a legal description, site plan, vicinity map, and topographic map, if reasonably available. While you should submit any plans required by the agency, you are not required to duplicate maps or detailed plans submitted with any permit applications related to this checklist.

The SWL is located in the 600 Area of the Hanford Site about 3.5 miles southeast of the 200 Areas in Section 20, T12N, R27E. location and topographic maps and site plans are contained in the closure and postclosure plan submitted with this checklist. 


\section{B. ENVIRONMENTAL ELEMENTS}

\section{Earth}

a. General description of the site (circle one): Flat, rolling, hilly, steep slopes, mountainous, other

The general description of the site is flat to gentle rolling.

b. What is the steepest slope on the site (approximate percent slope)?

The steepest slope of the site is 3 percent.

c. What general types of soil are found on the site (for example, clay, sand, grave1, peat, muck)? If you know the classification of agricultural soils, specify them and note any prime farmland.

The near-surface soils found at the SWL consist primarily of eolian and fluvial sands with some gravel. No farming is permitted on the site.

d. Are there surface indications or history of unstable soils in the immediate vicinity? If so, describe.

No.

e. Describe the purpose, type, and approximate quantities of any filling or grading proposed. Indicate source of fill.

The existing soil from the excavated trenches will be used for the interim cover. This will provide a 24 to 48 inch cover over the existing trenches. Construction of the interim cover will be devised to provide a 2 percent slope.

f. Could erosion occur as a result of clearing, construction, or use? If so, generally describe.

Some wind erosion currently occurs at the site due to the lack of vegetation and will likely continue until the proposed final cover is placed and vegetated.

g. About what percent of the site will be covered with impervious surfaces after project construction (for example, asphalt or buildings)?

Impervious materials will not be used for surfacing.

h. Proposed measures to reduce or control erosion, or other impacts to the earth, if any: 
SEPA Checklist

SWL Interim Closure

Page 4 of 14

The interim cover will meet the regulatory standard of 24 to 48 inches and graded at a 2 percent slope that will reduce and control erosion.

\section{Air}

a. What types of emissions to the air would result from the proposal (i.e., dust, automobile, odors, industrial wood smoke) during construction and when the project is completed? If any, generally describe and give approximate quantities if known.

Some dust will become airborne during closure activities (e.g., construction of the final cover). Exhaust gases will be generated by equipment (e.g., construction equipment and personnel vehicles) as closure and postclosure activities are carried out.

b. Are there any offsite sources of emissions or odors that may affect your proposal? If so, generally describe.

No.

c. Proposed measures to reduce or control emissions or other impacts to the air, if any:

None.

\section{Water}

a. Surface

1) Is, there any surface water body on, or in the immediate vicinity of, the site (including year-round and seasonal streams, saltwater, lakes, ponds, wetlands)? If yes, describe type and provide names. If appropriate, state what stream or river it flows into.

No.

2) Will the project require any work over, in, or adjacent to (within 200 feet of) the described waters? If yes, please describe and attach available plans.

Does not apply.

3) Estimate the amount of $\mathrm{fill}$ and dredge material that would be placed in or removed from surface water or wetlands and indicate the area that would be affected. Indicate the source of fill material.

Does not apply. 
4) Will the proposal require surface water withdrawals or diversions? Give general description, purpose, and approximate quantities if known.

No.

5) Does the proposal 7 ie within a 100 -year floodplain? If so, note location on the site. plan.

No.

6) Does the proposal involve any discharges of waste material to surface waters? If so, describe the type of waste and anticipated volume of discharge.

No.

b. Ground

1) Will groundwater be withdrawn, or will water be discharged to groundwater? Give general description, purpose, and approximate quantities if known.

The SWL groundwater monitoring network currently consists of thirteen wells. Each well will be sampled at least semiannually. Before a sample is collected from a well, approximately three borehole volumes of water will be withdrawn to purge the well. Less than 20,000 gallons of water are expected to be withdrawn each year in support of groundwater monitoring at the SWL.

2) Describe waste material that will be discharged into the ground from septic tanks or other sources, if any (for example: Domestic sewage; industrial, containing the following chemicals...; agricultural; etc.). Describe the general size of the system, the number of such systems, the number of houses to be served (if applicable), or the number of animals or humans the system(s) are expected to serve.

Does not apply.

c. Water Run-off (including storm water):

I) Describe the source of run-off (including storm water) and method of collection and disposal, if any (include quantities, if known). Where will this water flow? Will this water flow into other waters? If so, describe. 
Precipitation is a potential source of run-off. However, because of the relatively dry climate and the permeable nature of the upper layer of the cover and native soils, little, if any, run-off is expected. No run-off control structures are required. No surface water bodies exist in the vicinity of the SWL.

2) Could waste materials enter ground or surface waters? If so, generally describe.

The potential for leachate generation from the infiltration of precipitation and subsequent groundwater contamination will be minimized, if not eliminated, by construction of the interim cover. No surface water bodies exist in the vicinity of the SWL.

d. Proposed measures to reduce or control surface, ground, and run-off water impacts, if any:

No run-off control structures are required. No surface water bodies exist in the vicinity of the SWL.

\section{Plants}

a. Check or circle the types of vegetation found on the site:

$$
\text { deciduous trees: alder, maple, aspen, other }
$$
evergreen trees: fir, cedar, pine, other shrubs

$\bar{x}$ grass pasture crop or grain wet soil plants: cattail, buttercup, bulrush, skunk cabbage, other water plants: water lily, eelgrass, milfoil, other other types of vegetation

b. What kind and amount of vegetation will be removed or altered? The SWL currently is vegetated with a sparse cover of invader grasses. Placement of the interim cover will not disrupt any of the native vegetation. No excavation will occur.

c. List threatened or endangered species known to be on or near the site.

No plant species protected under the ESA, candidates for such protection, or species listed by the Washington State government have been observed in the vicinity of the SWL.

d. Proposed landscaping, use of native plants, or other measures to preserve or enhance vegetation on the site, if any. 
The interim cover will allow natural vegetation to develop.

\section{Animals}

a. Circle any birds and animals which have been observed on or near the site or are known to be on or near the site:

birds: hawk, heron, eagle, songbirds, other: NONE mammals: deer, bear, elk, beaver, other: NoNE fish: bass, salmon, trout, herring, shellfish, other: $\frac{N I A}{\text { NA }}$

b. List any threatened or endangered species known to be on or near the site.

No migratory bird species have been observed in the vicinity of the SWL. The SWL is not known to be used by any threatened or endangered species.

c. Is the site part of a migration route? If so, explain.

No. Information on the Hanford Site environment can be found in the documents referred to in the answer to checklist question $4 . \mathrm{c}$.

d. Proposed measures to preserve or enhance wildlife, if any:

None.

\section{Energy and Natural Resources}

a. What kinds of energy (electric, natural gas, oil, wood stove, solar) will be used to meet the completed project's energy needs? Describe whether it will be used for heating, manufacturing, etc.

Fossit fuels will be used to operate monitoring equipment and personnel vehicles.

b. Would your project affect the potential use of solar energy by adjacent properties? If so, generally describe.

No.

c. What kinds of energy conservation features are included in the plans of this proposal? List other proposed measures to reduce or control energy impacts, if any:

None. 


\section{Environmental Health}

a. Are there any environmenta] health hazards, including exposure to toxic chemicals, risk of fire and explosion, spill, or hazardous waste, that could occur as a result of this proposal? If so, describe.

Environmental health hazards are not expected as a result of this proposal. This proposal is designed to prevent the escape or exposure of waste from the SWL.

1) Describe special emergency services that might be required.

In the event of an emergency, fire, ambulance, and patrol assistance may be required. These services are available on the Hanford Site.

2) Proposed measures to reduce or control environmental health hazards, if any:

All existing waste will remain landfilled. The interim cover will be constructed to form a barrier over the waste.

b. Noise

1) What type of noise exists in the area which may affect your project (for example: traffic, equipment, operation, other)?

None.

2) What types and levels of noise would be created by or associated with the project on a short-term or a long-term basis (for example: traffic, construction, operation, other)? Indicate what hours noise would come from the site.

Equipment used to construct the interim cover will create the only significant amount of noise. The activity is considered a low-level noise activity that is undertaken on a weekly basis during normal business hours. The remote location of the SWL will prevent any detectable increase in noise levels off the Hanford Site.

3) Proposed measures to reduce or control noise impacts, if any:

Vehicles and equipment will meet manufacturers requirements for noise suppression.

\section{Land and Shoreline Use}

a. What is the current use of the site and adjacent properties? 
The SWL is part of the Hanford Site that contains many facilities for waste management and special nuclear material production. The SWL is a remotely located landfill.

b. Has the site been used for agriculture? If so, describe. No.

c. Describe any structures on the site.

The only structure onsite is an 8-foot high perimeter fence that encloses the facility. A trailer is located for operations personnel.

d. Will any structures be demolished? If so, what? No.

e. What is the current zoning classification of the site?

The Hanford Site is zoned as an Unclassified Use district by Benton County.

$f$. What is the current comprehensive plan designation of the site?

The 1985 Benton County Comprehensive Land Use Plan designated the Hanford Site as the "Hanford Reservation." Under this designation, 1 and on the Site may be used for "activities nuclear in nature." Non-nuclear activities are authorized "if and when the DOE approval for such activities is obtained."

g. If applicable, what is the current shoreline master program designation of the site?

Does not apply.

h. Has any part of the site been classified as an "environmentally sensitive" area? If so, specify.

No.

i. Approximately how many people would reside or work in the completed project?

People will not reside in the completed project nor will people be required to operate the facility on a daily basis. Activities will require limited inspection, maintenance, and monitoring activities.

j. Approximately how many people would the completed project displace?

One operator. 
k. Proposed measures to avoid or reduce displacement impacts, if any:

Operator will be assigned another activity.

1. Proposed measures to ensure the proposal is compatible with existing and projected land uses and plans, if any:

Does not apply (see response to checklist question B.8.f.).

9. Housing

a. Approximately how many units would be provided, if any?

Indicate whether high, middle, or low-income housing.

Does not apply.

b. Approximately how many units, if any, would be eliminated?

Indicate whether high, middle, or low-income housing.

Does not apply.

c. Proposed measures to reduce or control housing impacts, if any:

Does not apply.

10. Aesthetics

a. What is the tallest height of any proposed structure(s), not including antennas; what is the principal exterior building material(s) proposed?

The interim Gover will be 24 to 48 inches.

b. What views in the immediate vicinity would be altered or obstructed?

None.

c. Proposed measures to reduce or control aesthetic impacts, if any:

The interim cover is designed to return the site to near natural conditions.

\section{Light and Glare}

a. What type of light or glare will the proposal produce? What time of the day would it mainly occur?

None. 
b. Could light or glare from the finished project be a safety hazard or interfere with views?

No.

c. What existing offsite sources of light and glare may affect your proposal?

None.

d. Proposed measures to reduce or control light and glare impacts, if any:

Does not apply.

\section{Recreation}

a. What designated and informal recreational opportunities are in the immediate vicinity?

None.

b. Would the proposed project displace any existing recreational uses? If so, describe.

No.

c. Proposed measures to reduce or control impacts on recreation, including recreation opportunities to be provided by the project or applicant, if any:

None.

\section{Historic and Cultural Preservation}

a. Are there any places or objects listed on, or proposed for, national, state, or local preservation registers known to be on or next to the site? If so, generally describe.

The SWL is not listed on or proposed for inclusion on preservation registers. Additional information on the Hanford Site environment can be found in the documents referred to in the answer to checklist question 4.C.

b. Generally describe any landmarks or evidence of historic, archaeological, scientific, or cultural importance known to be on or next to the site.

No resources of historic, archaeologica1, scientific, or cultural importance are known to be on or next to the site. Additional information on the Hanford Site environment can be found in the documents referred to in the answer to checklist question 4.C. 
c. Proposed measures to reduce or control impacts, if any: Does not apply.

\section{Transportation}

a. Identify public streets and highways serving the site, and describe proposed access to the existing street system. Show on site plans, if any.

Does not apply.

b. Is the site currently served by public transit? If not, what is the approximate distance to the nearest stop?

The SWL is not publicly accessible and, therefore, is not served by public transit.

c. How many parking spaces would the completed project have? How many would the project eliminate?

None.

d. Will the proposal require any new roads or streets, or improvements to existing roads or streets, not including driveways? If so, generally describe (indicate whether public or private).

No.

e. Will the project use (or occur in the immediate vicinity of) water, rail, or air transportation? If so, generally describe. No.

f. How many vehicular trips per day would be generated by the completed project? If known, indicate when peak volumes would occur.

Inspection and monitoring of the facility will require visits several times a year to the site.

g. Proposed measures to reduce or control transportation impacts, if any:

Does not apply.

\section{Public Services}

a. Would the project result in an increased need for public services (for example: fire protection, police protection, health care, schools, other)? If so, generally describe. 
No.

b. Proposed measures to reduce or control direct impacts on public services, if any:

Does not apply.

16. Utilities

a. Circle utilities currently available at the site: electricity, natural gas, water, refuse service, telephone, sanitary sewer, septic system, other.

No public utilities exist onsite. The SWL is a remotely located 1 and $i 11$.

b. Describe the utilities that are proposed for the project, the utility providing the service, and the general construction activities on the site or in the immediate vicinity which might be needed.

No utilities are proposed. 
SEPA Checklist

SWL Interim Closure

Page 14 of 14

C. SIGNATURES

The above answers are true and complete to the best of my knowledge. I understand that the lead agency is relying on them to make its decision.

BANoluber

B. A. Holmberg, Manager

$1 / 3 / 46$

Transportation and Waste Handling

ICF Kaiser Hanford Company

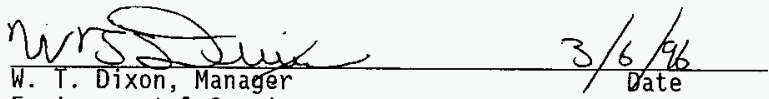

Environmental Services

Westinghouse Hanford Company
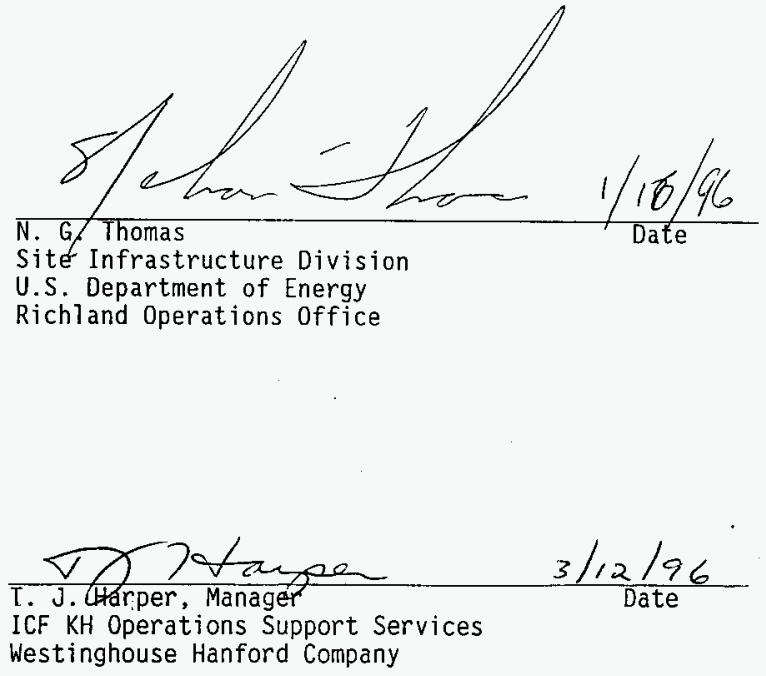
Ms. Robyn Morgan

ICF Kaiser Hawiond Company

P. O. Box 888, MSIN B4-20

Richland, WA 99352

Dear Ms. Morgan:

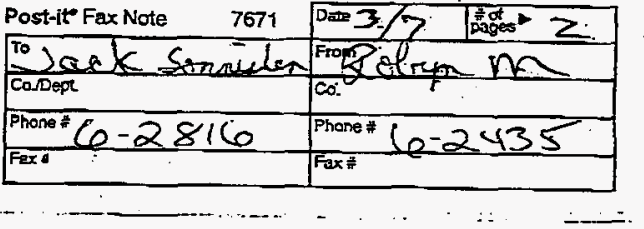

BIOLOGICAL REVIEW OF THE SOLID WASTE LANOFILL (SWL) CLOSURE PROJECT, 600 ATEa, \#95-600-053 - Amendment

\section{Project Description:}

- The Solid Waste Landfill (SWL) is designated to be closed by 12/31/95. A soil cap will be layered over the entire SWL area to a depth of approximately 30 inches $(76 \mathrm{~cm})$ total. The cap soil, approximately $80,000 \mathrm{cu}$. yards $(61,168 \mathrm{cu} . \mathrm{m})$, will be taken from the existing swh soll stockoile.

- This is an amendment to letter $\$ 96-600-053$ dated August 23, 1995. All changes have been underlined.

\section{Survey Objectives:}

- To determine the occurence in the project area of plant and animal species protected under the Endangered Species Act (ESA), candidates for such protection, and species listed as threatened. endangered, candidate, sensitive, or monitor by the state of Washington, and species protected under the Migratory Bird Treaty Act,

- To evaluate the potential impacts of distutbance on priority habitats and protected plant and animal species identified in the survey.

Survey Methods:

- Pedestrian and ocular reconnaissance of the proposed site was conducted by G. Fortner, and R. Zufelt on August 22, 1995. The Braun-Blanquet cover-abundance scale (Bonham 1989) was used to determine percent cover of dominant vegetation.

- Priority habitats and species of concern are documented as such in the following: Washington Department of Fish and Widlife $(1993,1994)$. U. S. Fish and Widlife Service $(1985,19942$ \& b) and Washington State Department of Natural Resources (1994).

Survey Fiesults:

- The vicinity of the SWL site has been previously disturbed. Vegetation is characteristic of disturbed areas and consists primarily of Russian thistle (Salsola kalh), cheargrass (Bromus tectorum,. Jim Hill's tumble mustard (Sisymbrium altissimum), and dune scurfpea (Psoralea lanceolata),

- No migratory bird species were observed nesting in the vicinity of the SWL site,

\section{Considerations and Recommendations:}

- This biological survey is effective untii April 1, 1996. At that time. a new ecological survey will be done.

- No other plant and animal species protected under the ESA, candidates for such protection, or species listed by the Washington state govemment were observed in the vicinity of the proposed sites, 
Ms. Morgan

95-600-053 - Amend

Page 2 of 3

- No adverse impacts to other species or habitats of concern are expected to occur from the proposed actions.

Sincerely,

Ofshand

CA Brandt, Ph.D.

Project Manager

Ecological Compliance Assessment

GAB:glf 


$$
-
$$


DOE/RL-90-38, Rev. 1

\section{CONTENTS}

2

3

4

5

6

7

8

9

10

11

12

13

$14 \quad 6.0$ REFERENCES

\subsection{INTRODUCTION}

2.0 FACILITY DESCRIPTION AND LOCATION INFORMATION

3.0 WASTE CHARACTERIZATION

4.0 INTERIM CLOSURE STRATEGY

5.0 INTERIM CLOSURE ACTIVITIES 
DOE/RL-90-38, Rev. 1

\section{CONTENTS (cont'd)}

2

3 APPENDIX A MAPS

4

5 APPENDIX B HELP MODEL RESULTS 
DOE/RL-90-38, Rev. 1

\section{LIST OF TERMS}

2

3

4
DOE

DOE-RL

Ecology

EII

EPA

GEODAT

HEIS

HELP

ICF KH

JAJ

NRC

NRDWL

RCRA

SWL

Tri-Party

Agreement

WAC

WHC
U.S. Department of Energy

U.S. Department of Energy-Richland Operations Office

Washington State Department of Ecology

Environmental Investigations Instruction

U.S. Environmental Protection Agency

Geosciences Data Analysis Toolkit

Hanford Environmental Information System

Hydrologic Evaluation of Landfill Performance

ICF Kaiser Hanford Company

J. A. Jones

Nuclear Regulatory Commission

Nonradioactive Dangerous Waste Landfill

Resource Conservation and Recovery Act of 1976

Solid Waste Landfill

Hanford Federal Facility Agreement and Consent Order

Washington State Administrative Code

Westinghouse Hanford Company 
DOE/RL-90-38, Rev. 1

1

2

4

5

This page intentionally left blank. 
DOE/RL-90-38, Rev. 1

\section{CONTENTS}

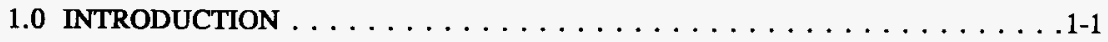

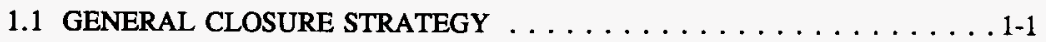

1.2 INTEGRATION OF CLOSURE ACTIVITIES $\ldots \ldots \ldots \ldots \ldots \ldots \ldots$ 


\section{DOE/RL-90-38, Rev. 1}

This page intentionally left blank. 


\subsection{INTRODUCTION}

This document describes the activities for interim closure of the Hanford Site Solid Waste Landfill (SWL) owned by the U.S. Department of Energy-Richland Operations Office (DOE-RL) and operated by the ICF Kaiser Hanford Company (ICF KH) under subcontract to the Westinghouse Hanford Company (WHC). Although the U.S. Government holds legal title to this facility, the DOE-RL, for purposes of defining the Resource Conservation and Recovery Act of 1976 (RCRA) facilities, is considered the legal owner.

The SWL is a land disposal unit located on the Hanford Site that has received municipal and sanitary waste of the type regulated under Washington State Department of Ecology (Ecology) "Minimum Functional Standards for Solid Waste Handling," Washington State Administrative Code (WAC) 173-304 (1988). The SWL has received waste from Hanford Site operations since 1973 and is scheduled to cease operations in March 1996. Beginning in April 1996, the SWL will begin a period of interim closure care. This plan is subject to change pending the need for corrective actions to protect human health and the environment.

\subsection{GENERAL CLOSURE STRATEGY}

The general strategy is to close the SWL in accordance with WAC 173-304-407 and WAC 173-304-460. Previously, a proposed closure plan for the SWL was submitted to Ecology as part of a landfill permit application (Hanford Site Solid Waste Landfill Permit Application [DOE-RL 1993]). Due to the discovery of subsurface contamination, closure activities cannot be properly identified in the closure and postclosure plans until the subsurface has been characterized and remedial activities, if any, have been identified. The corrective action program pursuant to WAC 172-490(3) is discussed to characterize the subsurface of the landfill to assess the extent of contamination in the vadose zone and groundwater (Corrective Action Plan for the Hanford Site Solid Waste Landfill [Hodges 1994]), to perform remedial actions identified as necessary from the characterization, and to develop the closure and postclosure plan. In the meantime, the SWL will be maintained and monitored as outlined in this interim closure plan.

Interim closure activities will be conducted to minimize any threat to human health and the environment. The following activities will be performed:

- All open trenches have been backfilled with 0.6 to 1.2 meters ( 2 to 4 feet) of native soil

- Once all the trenches have been backfilled, the surface of the burial ground will be graded and contoured to control run-on/run-off of surface water or precipitation

- All surface depressions that might serve as catchments will be eliminated

- All surface slopes will be limited to $3 \%$ 
- The groundwater monitoring program will be continued on a quarterly basis

- The landfill gas monitoring program will be continued on a quarterly basis

- Leachate monitoring from the lysimeter will be continued on a quarterly basis

- For addition inspection schedule for the Solid Waste Landfill, see Section 5.0, Table 5-1

- The SWL is secured by:

- Restricting access (access to the Hanford Site is controlled through the use of a 24-hour barricade system on all roads leading onto the Site)

- An 2.45-meter (8-foot) fence around the perimeter of the SWL. All gates will be secured.

\subsection{INTEGRATION OF CLOSURE ACTIVITIES}

The SWL is located adjacent to the Nonradioactive Dangerous Waste Landfill (NRDWL) which consists of a series of trenches containing chemical (dangerous), asbestos, and sanitary waste received from January 1975 through May 1988. The NRDWL ceased receiving dangerous waste in May 1985.

The NRDWL will be closed in accordance with WAC 173-303, Dangerous Waste Regulations. A separate closure and postclosure plan for the NRDWL was submitted to Ecology for review and approval in August 1990 (Closure and Postclosure Plan, Nonradioactive Dangerous Waste Landfill [DOE-RL]). Although the SWL and NRDWL are regulated under different WACs, their physical proximity and effective management require that certain activities between the two landfills be integrated.

Site monitoring and characterization activities at both the SWL and NRDWL have indicated certain contaminants are present within the vadose zone and in the groundwater'. A corrective action plan (Hodges 1994) was developed for performing further characterization in an effort to determine the extent and magnitude of the contamination at the SWL. The action plan has been approved by Ecology (Ecology letter of June 7, 1995 from David L. Lundstrom to James E. Rasmussen, DOE-RL). The efforts identified in the corrective action plan will be used to guide remedial activities at the SWL (Ecology letter of November 20, 1995 from Fenggang Ma to James E. Rasmussen [DOE-RL]). Until subsurface characterization is performed and remedial activities are identified, cost effective closure activities for either landfill cannot be selected.

The interim closure activities for the SWL are described in Chapter 5.0. 


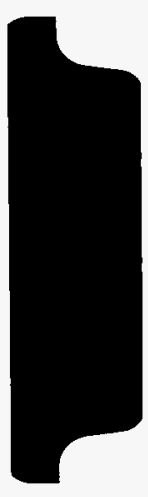


DOE/RL-90-38, Rev. 1

2.0 FACILITY DESCRIPTION AND LOCATION INFORMATION $\ldots \ldots \ldots \ldots$. 2 -1

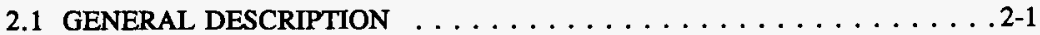

2.1.1 Hanford Site . . . . . . . . . . . . . . . 2-1

2.1.2 Solid Waste Landfill . . . . . . . . . . . . . . 2-1

2.1.3 Nonradioactive Dangerous Waste Landfill . . . . . . . . 2-4

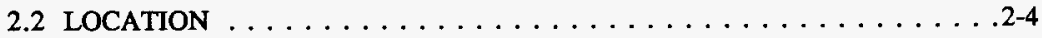

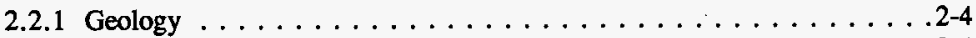

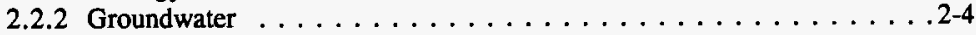

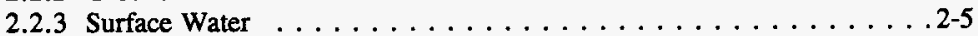

2.2 .4 Slope $\ldots \ldots \ldots \ldots \ldots \ldots \ldots \ldots \ldots \ldots \ldots \ldots \ldots \ldots \ldots \ldots \ldots \ldots \ldots \ldots . .2-5$

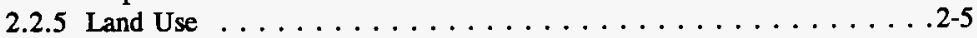

2-1 Hanford Site and Regional Map . . . . . . . . . . . . . F2-1

2-2 Map of the Solid Waste Landfill and Nonradioactive Dangerous Waste Landfill Illustrating the Landfill Arrangement . . . . . . . . . . . . . . . . . F2-2

2-3 Aerial Photograph of the Solid Waste Landfill Looking Southwest 
DOE/RL-90-38, Rev. 1

1

2

3

4

5

This page intentionally left blank. 


\subsection{FACILITY DESCRIPTION AND LOCATION INFORMATION}

This chapter describes the Hanford Site and provides a general overview of the SWL.

\subsection{GENERAL DESCRIPTION}

This section discusses the general Hanford Site operating areas and introduces the SWL.

\subsubsection{Hanford Site}

The Hanford Site covers approximately 1450 square kilometers (560 square miles) of semiarid land. The site is located northwest of the city of Richland, Washington (Figure 2-1). The city of Richland adjoins the southernmost portion of the Hanford Site boundary and is the nearest population center. In early 1943, the U.S. Army Corps of Engineers selected this site as the location for reactors, chemical separations, and related activities for the production and purification of special nuclear materials and other nuclear activities. The current mission at the Hanford Site is waste management and environmental restoration and remediation activities.

The Hanford Site is divided into numerically designated areas (Drawing H-6-958 in Appendix A). The reactors are located along the Columbia River in the 100 Areas.

The reactor fuel reprocessing units are in the 200 Areas, which are on a plateau approximately eleven kilometers (seven miles) from the Columbia River. The 300 Area, located just north of Richland, contains the reactor fuel manufacturing plants and the research and development laboratories. The 400 Area, eight kilometers (five miles) northwest of the 300 Area, contains the Fast Flux Test Facility designed for testing liquid metal reactor systems. The 600 Area covers all locations not specifically given an area designation. Within and adjacent to northern Richland, the 1100 Area contains offices associated with administration, maintenance, transportation, and the procurement and distribution of materials. The 3000 Area, between the 1100 Area and 300 Area, contains engineering offices and administrative offices. Also, administrative offices are located in the 700 Area in downtown Richland.

\subsubsection{Solid Waste Landfill}

The SWL is a land disposal facility located near the geographic center of the Hanford Site in the 600 Area (Figure 2-1). The SWL covers approximately 26.7 hectares (66 acres) and has been operating since 1973. The landfill, regulated under WAC 173-304, received sanitary solid waste from Hanford Site operations. In addition to sanitary waste, the SWL received asbestos waste material regulated under 40 Code of Federal Regulations [CFR] 61, Subpart M, "National Emission Standard for Asbestos." The SWL did not accept waste 
1 from the general public. Disposal of radioactive waste, and dangerous waste are prohibited.

2 Disposal of free liquids has been prohibited since April 1987. The waste types and inventory

3 are described in Chapter 3.0 of the landfill permit application (DOE-RL 1993).

Figure 2-2 illustrates the site plan for the SWL, identifying the size, site structures, trench locations, and boundary. The SWL is approximately 907 meters $(2,977$ feet) in length and 294 meters ( 965 feet) in width. It is divided into five units, each consisting of a series of parallel trenches. The two oldest units are identified as the Phase I area. The Phase II area is divided into three units: north, middle, and south. The Phase I area and the northern two units of the Phase II area have been filled and are considered inactive. Currently, only the south unit of the Phase II area is being filled and is scheduled to cease operations in March 1996. An aerial photograph of the SWL is provided in Figure 2-3. A topographic map is provided in Appendix A.

The United States Government owns the SWL, adjacent properties, all right-of-ways, roads, and mineral rights. Figure 2-1 shows the location of access roads. Hauling routes to the SWL are along paved highways. Army Loop Road, which is the approach road for the SWL, is a paved, permanent roadway approximately 7.3 meters $(24 \mathrm{feet})$ wide. Within the SWL, onsite routing of trucks to currently active trenches is by temporary roads.

2.1.2.1 Operational History. The site of the present SWL originally was designated as the Central Landfill. The Central Landfill began operating in 1973 and received sanitary waste, asbestos, and construction and demolition debris from Hanford Site operations. The landfill also received small quantities of sewage and liquid waste beginning in 1974 (DOE-RL 1993). The first waste disposal trench opened was the J. A. Jones (JAJ) trench, named after the contractor that performed the excavation work (Figure 2-2).

The Central Landfill (approximately 15.4 hectares [38 acres]) was subdivided into three units for operational purposes. In 1975, the northernmost unit of the Central Landfill (approximately 4 hectares [10 acres]) was isolated for the disposal of asbestos waste materials and nonradioactive chemical waste (as designated by waste management). Because of the presence of regulated dangerous waste, this northernmost unit was designated formally as the NRDWL (see Section 2.1.3) and is regulated under RCRA as a land disposal facility following the submittal of a RCRA Part A permit application. The remainder of the Central Landfill was designated as the SWL and is now designated as the SWL Phase I area which was operated from 1973 through 1982 . The boundary line separating the NRDWL from the SWL is located halfway between the trench designated as JAJ and the southern border of NRDWL trenches 20 through 34 .

In 1982, the SWL was extended 15.4 hectares ( 38 acres) to the south. The extension is designated as the SWL Phase II area which has been in operation since 1982. General operational dates for different areas of the SWL Phase II are provided in Figure 2-2.

The NRDWL continued to receive asbestos waste until 1988, at which time the NRDWL was operationally closed. Since that time, all Hanford Site asbestos waste has been disposed 
1 of in dedicated trenches in the Phase II area of the SWL. Currently and in the past, asbestos

The SWL's solid waste disposal operation and environmental monitoring program were designed to meet the applicable requirements in WAC 173-304-460, WAC 173-304-405, and WAC 173-304-600. The SWL has received solid waste since 1973 and is scheduled to cease operations in March 1996. Due to waste minimization efforts at the Hanford Site, operations were extended six months from the schedule identified in the permit application (DOE-RL 1993) and the SWL will close as it approaches, but before being filled to maximum capacity. The maximum capacity of the landfill is estimated at 596,000 cubic meters $(780,000$ cubic yards). The SWL plan of operation is presented in Chapter 5.0 of the landfill permit application (DOE-RL 1993). The environmental controls and monitoring activities are described in Sections 5.3 and 5.4, and Appendices $5 G$ through 5 I of that same reference.

Activities at the SWL have been managed by four companies under contract to the U.S. Department of Energy: Atlantic Richfield Company (1973 to July 1977), Rockwell Hanford Company (July 1977 to June 1987), Westinghouse Hanford Company (July 1987 to December 1993), and ICF Kaiser Hanford Company (January 1994 to the present) under subcontract to Westinghouse Hanford Company.

\subsubsection{Facility Structures and Utilities. Several structures were placed on the SWL site} to support operations, including a mobile trailer, portable toilet, electrical generator, lysimeter monitoring station, and perimeter fence. The trailer served as office and lunchroom space for landfill operators and contains hand-washing facilities. A portable diesel-powered generator provided electricity to the trailer, and operating personnel hand-carried drinking water to the site. A portable chemical toilet was located just outside the trailer. The lysimeter monitoring station was placed on the riser to the outfall pipe. The station enables samples to be taken with compressed inert gas forcing the leachate from the collection device to the sample container. This method eliminates the need for entering a confined space. No public utilities exist at the SWL.

A permanent perimeter fence 2.4 meters ( 8 feet) tall surrounds the SWL and separates the Phase I area from the Phase II area and the NRDWL. The fence has several lockable gates. The mobile trailer was placed adjacent to the principal access gate which is located on the southeast side of the SWL. The principal access is Army Loop Road. Within the landfill, onsite routing of trucks to active trenches was via temporary roads. Temporary roads were built, as needed, by compacting the native soil and, if necessary, topping the soil with 0.2 to 0.3 meters ( 8 to 12 inches) of pit-run gravel or cobble.

2.1.2.3 Waste Characterization. The SWL received a variety of nonhazardous, nonradioactive sanitary solid wastes generated from Hanford Site operations. The majority of waste consists of office-type waste, asbestos material, and construction and demolition debris. See Chapter 3.0 for a discussion on the types of waste placed within the SWL. 


\subsubsection{Nonradioactive Dangerous Waste Landfill}

The NRDWL is directly adjacent to the north side of the SWL. It is an inactive dangerous waste landfill regulated under WAC 173-303. The NRDWL will be closed in accordance with WAC 173-303 regulations and the requirements of the Hanford Federal Facility Agreement and Consent Order (Tri-Party Agreement) between Ecology, DOE, and the EPA (Ecology et al. 1992). A closure and postclosure plan (DOE-RL 1990) describing the closure strategy and schedule for the NRDWL has been submitted to Ecology for approval. The proposed closure strategy includes the construction of a final closure cover. A proposed closure strategy for the SWL was submitted to Ecology as part of a landfill permit application (DOE-RL 1993). Although the SWL and NRDWL are regulated under different WACs, their physical proximity and effective management require that certain activities between the two landfills be integrated.

\subsection{LOCATION}

This section describes the location of the SWL with respect to the applicable standards of WAC 173-304-130(2), including geologic, hydrologic, and land-use considerations. Discussions are provided to demonstrate that each standard has been met.

\subsubsection{Geology}

The trenches in the SWL have been excavated in eolian and glaciofluvial sediments. Bedrock, consisting of basalt, is found at a depth of approximately 183 meters (600 feet) below the SWL. The SWL is not located over or adjacent to any known geologic features or structures that could compromise the structural integrity of the landfill. No active faults or evidence of a fault with displacement occurring during Holocene time have been found at the Hanford Site (Site Characterization Plan, Reference Repository Location, Hanford Site, Washington [DOE 1988]; Geology and Hydrology of the Hanford Site: A Standardized Text for Use in Westinghouse Hanford Company Documents and Reports [WHC 1991]). The youngest faults recognized at the Hanford Site occur on Gable Mountain, over 8 kilometers (5 miles) north of the SWL. These faults are of Quaternary age and are considered "capable" by the Nuclear Regulatory Commission (NRC) (Safery Evaluation Report Related to the Operations of WPPSS Nuclear Project No. 2 [1982]). A detailed description of the geology of the SWL is in Chapter 4.0 of the landfill permit application (DOE-RL 1993).

\subsubsection{Groundwater}

The water table is located at a depth of approximately 38 meters (125 feet) beneath the SWL. The SWL is not located over a "sole source aquifer" as defined in Section 1424(e) of the Safe Drinking Water Act of 1974. The closest downgradient well for drinking water is 
1 located more than 9.7 kilometers (6 miles) from the SWL in the 400 Area. A detailed

2 description of the hydrology of the SWL is in Chapter 4.0 of the landfill permit application

3 (DOE-RL 1993).

\subsubsection{Surface Water}

The SWL is not near any surface water. The Columbia River is more than 9.7 kilometers (6 miles) from the SWL and Cold Creek (ephemeral) is approximately 6.4 kilometers (4 miles) away. The SWL is not located near any wetland or any public land that is being used by a public water system. Surface water bodies are shown on the topographic map in Appendix A.

\subsubsection{Slope}

The terrain surrounding the landfill is relatively flat to gently rolling. The surface geology consists of stabilized dune sand. There are no known naturally unstable hillsides or soils within or adjacent to the SWL (see topographic map in Appendix A).

\subsubsection{Land Use}

The site map in Figure 2-1 illustrates land use around the SWL. The SWL is located in a remote area of the Hanford Site; the closest Hanford Site building is in the 200 East Area more than 4.8 kilometers ( 3 miles) away. The city of Richland is the nearest population center and the closest airport is more than 22.5 kilometers (14 miles) away.

The area surrounding the SWL has not been designated as critical habitat for endangered 31 adjacent to the Hanford Site. 
DOE/RL-90-38, Rev. 1

1

2

3

4

5

This page intentionally left blank. 
DOE/RL-90-38, Rev. 1

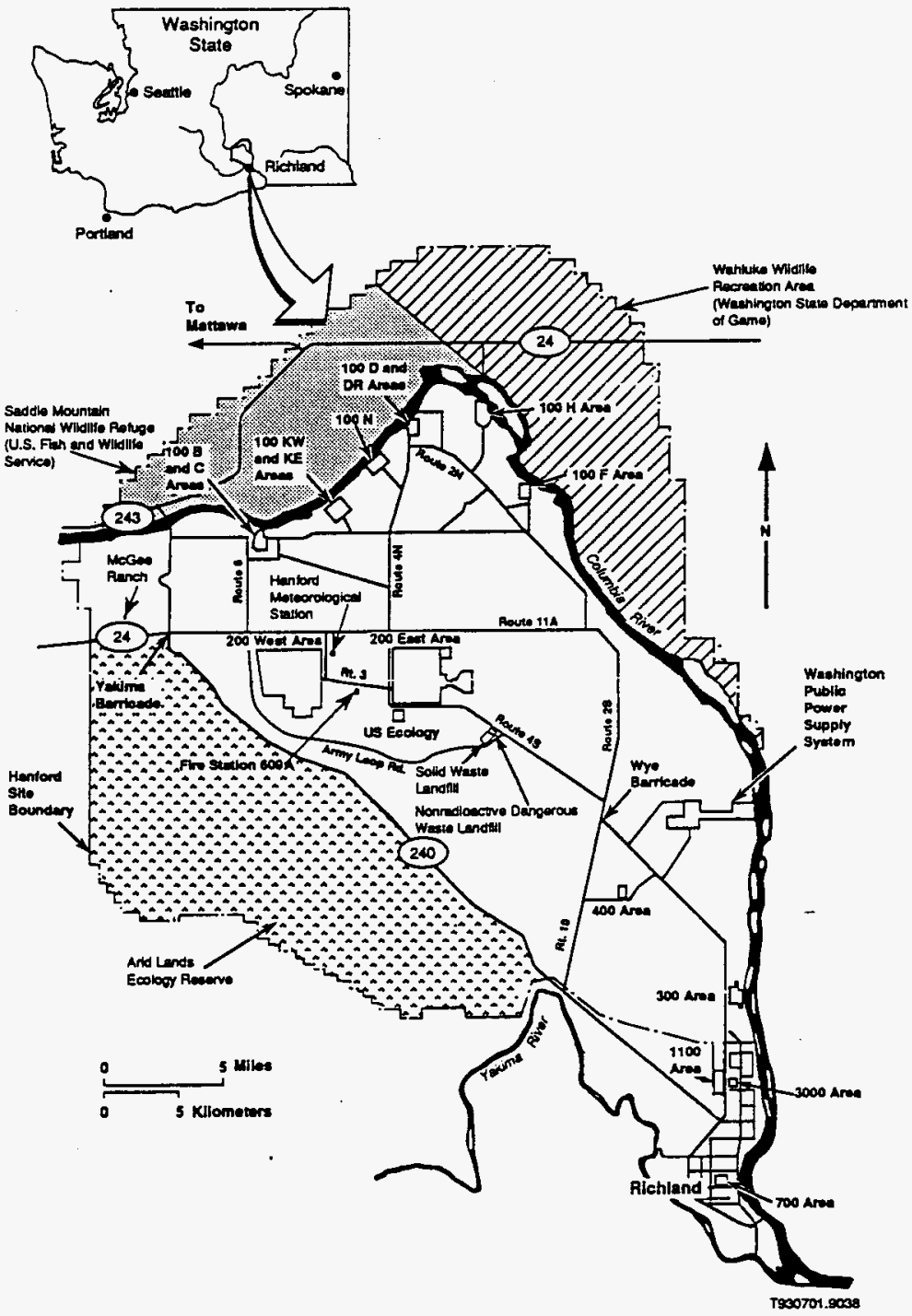

Figure 2-1. Hanford Site and Regional Map. 


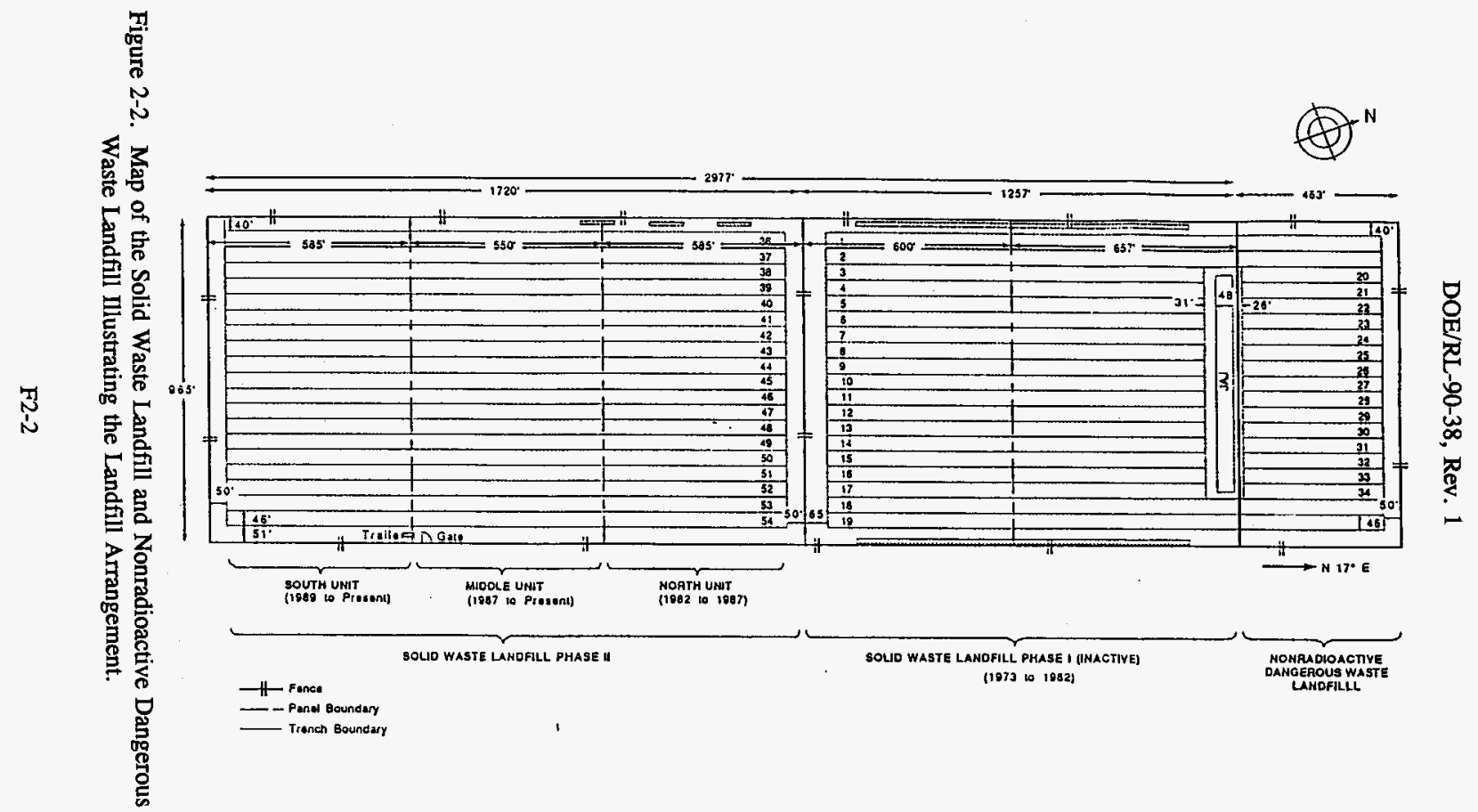


DOE/RL-90-38, Rev. 1

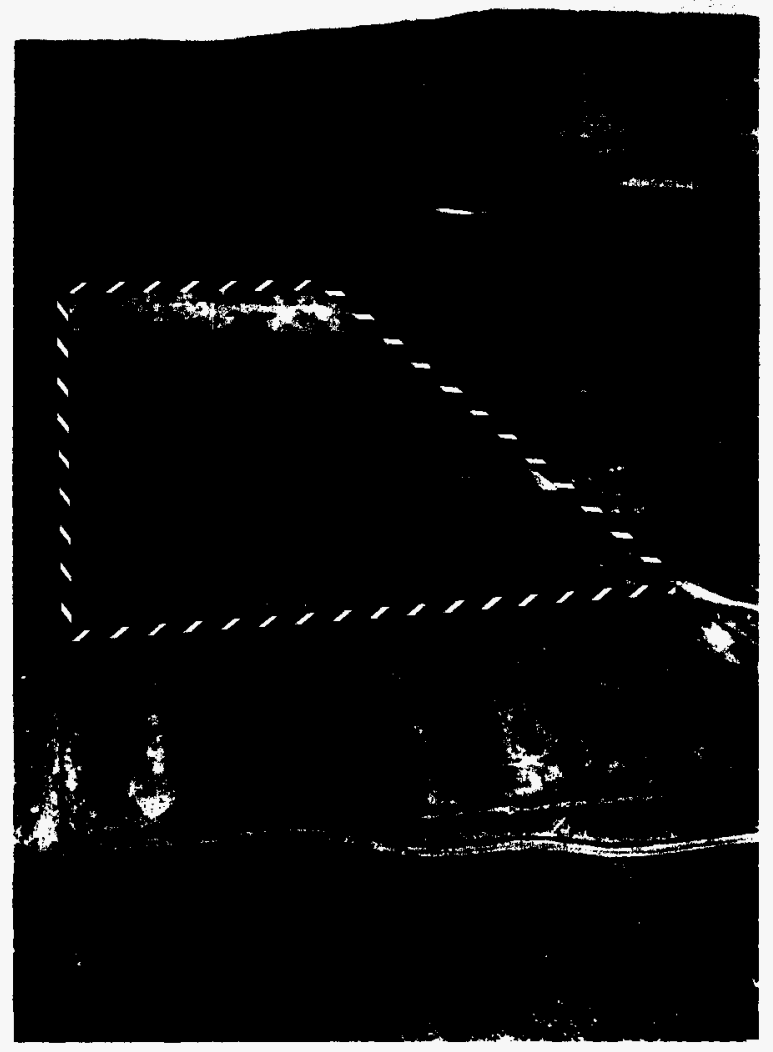

90062924-1CN

(PHOTO TAKEN 1990)

Figure 2-3. Aerial Photograph of the Solid Waste Landfill Looking Southwest. 


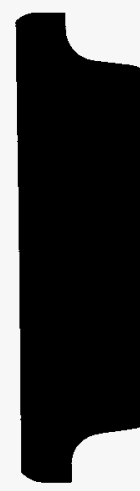


DOE/RL-90-38, Rev. 1

3-1 Map of the Solid Waste Landfill Showing Liquid Disposal Sites . . . . . . . . . F3-1

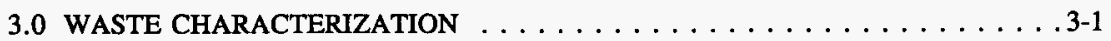

3.1 WASTE TYPES $\ldots \ldots \ldots \ldots \ldots \ldots \ldots \ldots \ldots \ldots \ldots \ldots \ldots \ldots \ldots$

3.2 WASTE INVENTORY $\ldots \ldots \ldots \ldots \ldots \ldots \ldots \ldots \ldots \ldots \ldots \ldots \ldots \ldots .2$

\section{FIGURES}

3-2 Typical Trench Cross-Section of the Two Types of Trenches

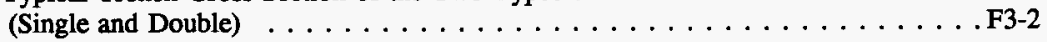

\section{TABLE}

3-1 Solid Waste Landfill Inventory, 1973 through $1992 \ldots \ldots \ldots$. . . . . . . T3-1 
DOE/RL-90-38, Rev. 1

1

2

3

4

5

This page intentionally left blank. 


\subsection{WASTE CHARACTERIZATION}

The SWL received a variety of nonhazardous, nonradioactive sanitary solid wastes generated from Hanford Site operations. The majority of waste consists of office-type waste, asbestos material, and construction and demolition debris. The SWL does not accept waste from the general public. This chapter describes the general characteristics of the waste disposed of at the SWL and provides inventory information.

\subsection{WASTE TYPES}

The types of waste disposed of at the SWL are categorized (based on recent waste receipts) as follows:

- Office waste

- Construction and demolition debris

- Asbestos material

- Bulky items

- Other.

Approximately 40 percent of the total volume of waste disposed of in the SWL is office waste consisting largely of waste paper products.

Construction and demolition debris resulted from construction activities and the demolition or renovation of buildings. Large quantities of waste wood from Hanford Site operations (e.g., wooden pallets) also were included in this category. Construction and demolition debris consisted mainly of wood and wood products and represented approximately 30 percent of the total volume of waste.

Asbestos material is asbestos or material containing asbestos that is nonradioactive and nonhazardous. Asbestos material accounts for approximately 10 percent (by volume) of all waste disposed of at the SWL. The bulk of the asbestos material comes from the demolition and/or renovation activities to buildings on the Hanford Site. Asbestos waste is disposed of in accordance with 40 CFR 61 Subpart $M$.

Bulky items include large items of refuse, such as appliances and office furniture, that typically do not fit into solid waste collection containers. This waste category represents approximately 10 percent of the total waste volume.

The "other" category consists of miscellaneous waste types that contribute minor amounts to the total waste volume. This category includes garbage from Hanford Site personnel lunches; industrial waste, such as packaging and empty containers; medical waste from first-aid stations; and various inert materials. This category is estimated to make up 10 percent of the total waste volume. 
1 Depending on the waste type, waste is placed in one of two types of trenches. Asbestos 2 debris is disposed of in a separate, specifically designated trench. All other waste is 3 disposed of in "general" sanitary waste trenches.

Before April 1987, the SWL received sewage and 1100 Area catch tank liquids in separate shallow trenches. These trenches that received liquid wastes are located along the east and west sides of the SWL (see Figure 3-1). Until 1982, the sewage was disposed of in two long trenches on the west and east perimeter in the Phase I area. From 1982 until April 1987, the sewage was released into one of three short trenches located on the northwest perimeter of the Phase II area. The sewage originated from portable toilets and septic tanks. Catch tank liquid from the 1100 Area heavy equipment garage and bus shop also was disposed of in these short trenches (from January 1985 through January 1987). The results of a chemical analysis of the 1100 Area catch tank liquid are provided in Appendix 4F of the permit application (DOE-RL 1993).

Since 1987, no sewage or other liquids were accepted for disposal at the SWL. All liquid trenches have operational covers in place and are inactive. Disposal of radiological and/or dangerous waste at the SWL is prohibited.

\subsection{WASTE INVENTORY}

Based on the most recent waste receipts, the SWL received approximately 30,600 cubic meters (40,000 cubic yards) of solid waste per year. As discussed in Section 3.1, liquid has been disposed of in several shallow SWL trenches. An estimated $3,800,000$ to $5,700,000$ liters $(1,000,000$ to $1,500,000$ gallons) of sewage were discharged to the liquid trenches from 1975 to April 1987. The average daily sewage disposal during this period was approximately 11,400 liters (3,000 gallons). An estimated 380,000 liters (100,000 gallons) of 1100 Area catch tank liquid was discharged to liquid trenches from 1985 through 1987. A summary of the estimated volume of sanitary solid waste, asbestos waste material, and free liquid disposed of in the SWL since 1973 is provided in Table 3-1. It should be noted that before 1982, no detailed log of waste types and volumes was maintained for the SWL. In 1982, following the extension of the landfill, weekly inventory logs were initiated. At a later date, inventory and inspection procedures were expanded to require daily, weekly, and monthly logs.

Based on trench geometry and the thickness of the waste layer, the capacity of a trench per linear foot is approximately 30 cubic meters ( 40 cubic yards) for the double trench and approximately 8.4 cubic meters (11 cubic yards) for the single trench (Figure 3-2). This volume includes the space occupied by the daily cover. Based on these calculations, the capacity of the Phase I area (which consists of only single trenches) is estimated as 179,000 cubic meters $(234,000$ cubic yards), and the Phase II area (which consists of both single and double trenches) is estimated as 417,000 cubic meters (546,000 cubic yards). The design capacity of the entire SWL is estimated to be 596,000 cubic meters

44

45 (780,000 cubic yards). The landfill will cease operating prior to reaching its capacity. 
DOE/RL-90-38, Rev. 1
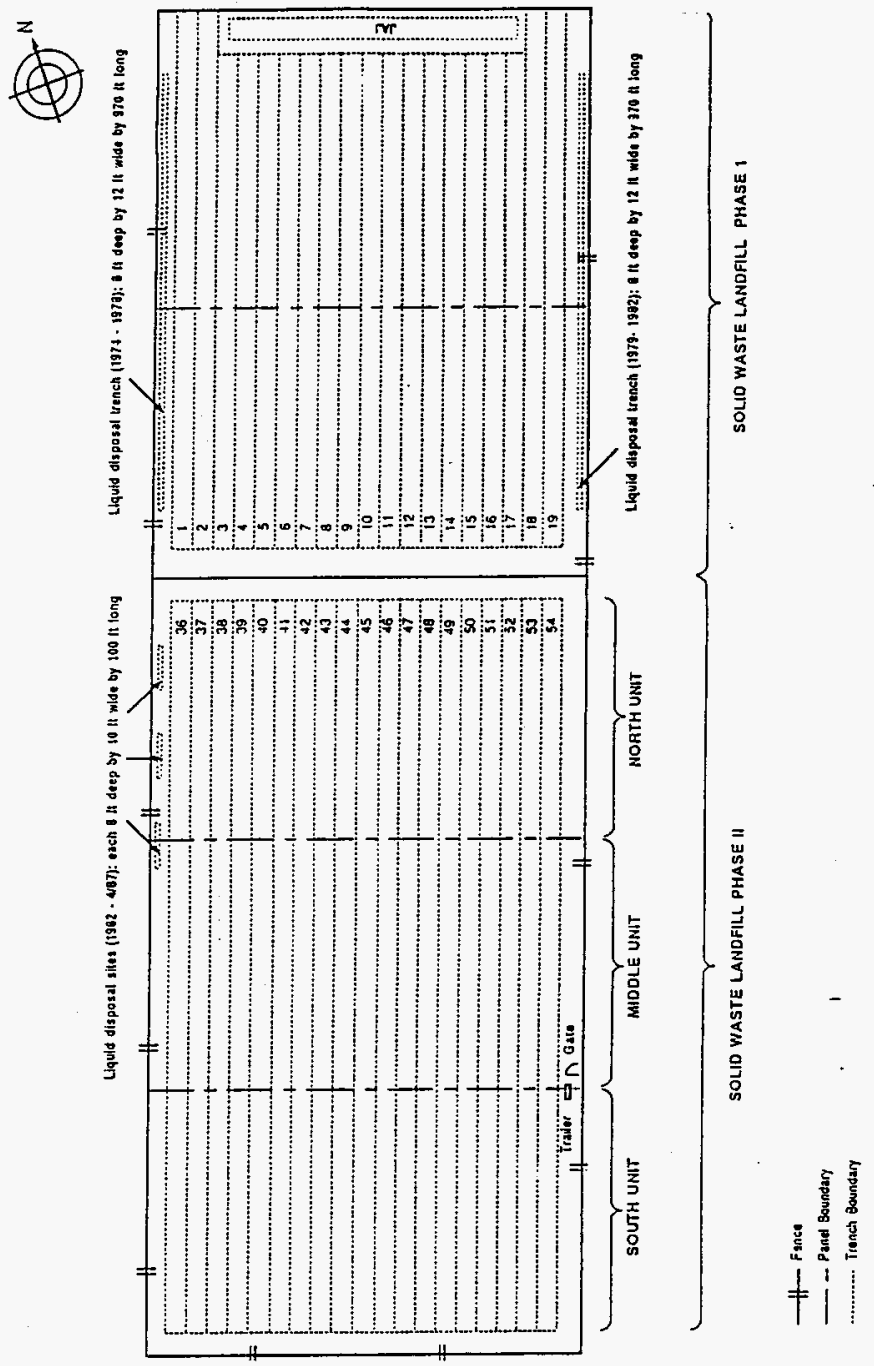

Figure 3-1. Map of the Solid Waste Landfill Showing Liquid Disposal Sites. 
资



46

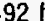

1-It Cobble or Gravel Layer

4-1t Operational Cover

Approximale
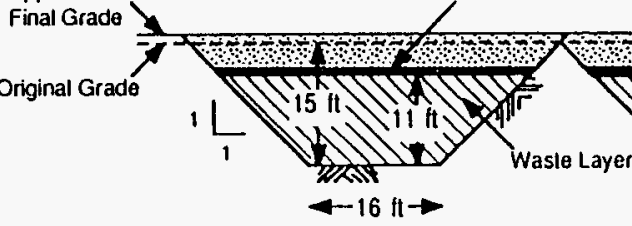

Single Trench

\section{Double Trench}

CDW5.1/101990 
DOE/RL-90-38, Rev. 1

\section{3}

Date

Table 3-1. Solid Waste Landfill Inventory, 1973 through 1992.

\begin{tabular}{|c|c|c|c|c|}
\hline 3 & Date & $\begin{array}{c}\text { Solid } \\
\text { cubic meters }\left(\mathrm{yds}^{3}\right)\end{array}$ & $\begin{array}{c}\text { Asbestos } \\
\left.\text { cubic meters (yds }{ }^{3}\right)\end{array}$ & $\begin{array}{c}\text { Liquid } \\
\text { liters (gallons) }\end{array}$ \\
\hline 4 & 1973-1982 & $4,200 \quad(5,500)$ & $359 \quad(470)$ & \\
\hline 5 & $1975-1981$ & & & $1,325,000(350,000)$ \\
\hline 6 & 1982 & (850) & (10) & $189,300 \quad(50,000)$ \\
\hline 7 & 1983 & $1,070 \quad(1,400)$ & (15) & $707,900(187,000)$ \\
\hline 8 & 1984 & $31,300(41,000)$ & $562 \quad(735)$ & $636,000(168,000)$ \\
\hline 9 & 1985 & $32,900(43,000)$ & $562 \quad(735)$ & $836,600(221,000)$ \\
\hline 10 & 1986 & $42,800(56,000)$ & $956(1,250)$ & $575,400(152,000)$ \\
\hline 11 & 1987 & $44,300(58,000)$ & $665 \quad(870)$ & $371,000 \quad(98,000)$ \\
\hline 12 & 1988 & $42,800(56,000)$ & $776(1,015)$ & $\mathbf{0}$ \\
\hline 13 & 1989 & $44,300(58,000)$ & $2,982(3,900)$ & 0 \\
\hline 14 & 1990 & $36,307(47,488)$ & $614 \quad(803)$ & 0 \\
\hline 15 & $1991^{*}$ & $21,073(27,563)$ & $1,161(1,518)$ & 0 \\
\hline 16 & 1992 & $22,220(29,063)$ & $1,017(1,330)$ & 0 \\
\hline 17 & 1993 & $25,800(33,745)$ & $1,508(1,973)$ & 0 \\
\hline 18 & 1994 & $28,791(37,655)$ & $2,062(2,697)$ & 0 \\
\hline 19 & 1995 & $21,755(28,452)$ & $1,252(1,637)$ & 0 \\
\hline $\begin{array}{l}21 \\
22 \\
23 \\
24 \\
25 \\
26 \\
27 \\
28 \\
29 \\
30 \\
31 \\
32\end{array}$ & $\begin{array}{l}\text { Notes: } \\
\text { Volumetric data ar } \\
\text { Solid waste volum } \\
\text { values. } \\
\text { Ashestos waste vo } \\
\text { Liquid waste volur } \\
\text { capacities of trans } \\
\text { Free liquid was pr } \\
\text { * In 1991, manage } \\
\text { foot of trench used per } \\
\text { consideration, a chang } \\
\text { not include the amount } \\
\text { amount of the waste di }\end{array}$ & $\begin{array}{l}\text { from annual letter reports } \\
\text { les are based on the capaci } \\
\text { e summarized from asbest } \\
\text { luding sewage and } 1100 \mathrm{~A} \\
\text { cles (tanker trucks). } \\
\text { from disposal at the SWL } \\
\text { dified the technique for re } \\
\text { multiply that by a per foot } \\
\text { plemented to use the daily } \\
\text { fill (cover) material in the }\end{array}$ & $\begin{array}{l}\text { the SWL operation. } \\
\text { of a typical trench and sho } \\
\text { disposal request forms (Ch } \\
\text { catch tank liquid, are base } \\
\text { of May } 1987 \text {. } \\
\text { rting volumes. The old m } \\
\text { pacity, and report that as } \\
\text { volumes of waste. The } \\
\text { l volume, so the volume r }\end{array}$ & $\begin{array}{l}\text { uld be considered maximum } \\
\text { apter 5.0, DOE-RL 1993). } \\
\text { d on estimated numbers and } \\
\text { ethod was to measure each } \\
\text { vaste. After careful } \\
\text { rolumes from the daily logs do } \\
\text { eported is a more accurate }\end{array}$ \\
\hline
\end{tabular}


DOE/RL-90-38, Rev. 1

1

2

3

4

5

This page intentionally left blank. 


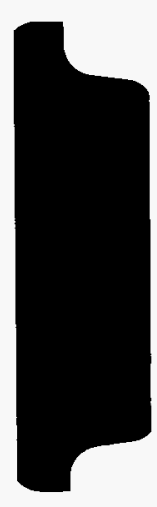


DOE/RL-90-38, Rev. 1

4.0 INTERIM CLOSURE STRATEGY $\ldots \ldots \ldots \ldots \ldots \ldots \ldots \ldots \ldots \ldots$ 4-1

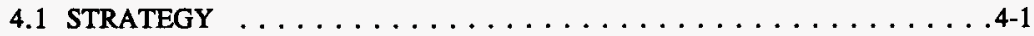

4.1 .1 Integration of Closure Activities $\ldots \ldots \ldots \ldots \ldots . \ldots$ 4-1

4.2 PERFORMANCE STANDARDS $\ldots \ldots \ldots \ldots \ldots \ldots \ldots \ldots \ldots$

4.2.1 Asbestos Cover Requirements . . . . . . . . . . . . . . 4-2 . . . . . . . . . . .

4.2.2 Groundwater Monitoring Requirements . . . . . . . . . . . 4-3

4.2.3 Landfill-Gas Monitoring and Control . . . . . . . . . . . . 4-3

4.2.4 Maintenance Considerations . . . . . . . . . . . . . 4-3

4.3 INTERIM CLOSURE STRATEGY $\ldots \ldots \ldots \ldots \ldots \ldots \ldots \ldots$

4.3 .1 Interim Cover $\ldots \ldots \ldots \ldots \ldots \ldots \ldots \ldots \ldots$. . . . . . . . . . . . . . . . . . . .

4.3.2 Landfill Gas Control . . . . . . . . . . . . . . . . . . 4-10

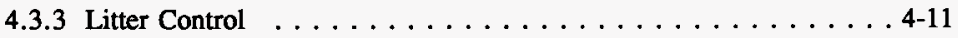

4.3.4 Vector Control . . . . . . . . . . . . . . . . . 4-11

4.3.5 Dust Control ...................... . 4-11

4.4 ENVIRONMENTAL MONITORING . . . . . . . . . . . . . . . . . 4-12

4.4.1 Groundwater Monitoring . . . . . . . . . . . . . . . 4-12

4.4.2 Vadose Zone Monitoring . . . . . . . . . . . . . . . . . 4-14

4.4.3 Landfill Gas Monitoring . . . . . . . . . . . . . . . . . 4-15

4.5 RECORD KEEPING AND REPORTING . . . . . . . . . . . . . 4-16

4.5 .1 Record Keeping . . . . . . . . . . . . . . . . . . . . . . . . . . . . . . . . . . . . . . .

4.5 .2 Reporting Requirements . . . . . . . . . . . . . . . 4-18

4.6 SECURITY INFORMATION . . . . . . . . . . . . . . 4-18

4.7 AMENDMENT OF PLAN . . . . . . . . . . . . . . . . 4-19 
DOE/RL-90-38, Rev. 1

1

2

3

4

5

6

7

\section{FIGURES}

4-1 Construction Diagram for a Typical Groundwater Monitoring Well at the Solid Waste Landfill . . . . . . . . . . . . . . . . . . . . . F4-1

4-2 Map of the Solid Waste and Nonradioactive Dangerous Waste

Landfills Showing the Groundwater Monitoring Wells . . . . . . . . . . F4-2

4-3 Diagram of Basin Lysimeter . . . . . . . . . . . . . . . . . F4-3 


\subsubsection{Integration of Closure Activities}

The SWL is located adjacent to the NRDWL. The NRDWL will be closed in accordance with WAC 173-303. A separate closure and postclosure plan for the NRDWL was submitted to Ecology for review and approval in August 1990 (DOE-RL). The physical proximity of the two sites suggests that the closure activities of the two landfills should be integrated in order to effectively manage both sites.

The proposed closure strategy for both the SWL and NRDWL is to close as a landfill, leaving all existing waste in place. Specifically, the SWL will close in accordance with WAC 173-304-407 and WAC 173-304-460, and the NRDWL will close in accordance with WAC 173-303-610 and WAC 173-303-665(6).

Both landfills require a final cover. A single final cover design has been proposed for the entire SWL in the landfill permit application (DOE-RL 1993). The proposed NRDWL final cover has been designed as two different covers, one cover for the chemical trenches and one cover for the sanitary and asbestos waste trenches. The cover design for the NRDWL cover over sanitary and asbestos waste trenches is the same as the cover design for 
1 the entire SWL. The proposed design to cover the sanitary and asbestos waste trenches is

2 equivalent in performance to the closure design standards of WAC 173-304-460(3)(e) and

3 meets the asbestos closure requirements of 40 CFR 61 . The chemical trench cover is

4 intended to satisfy the requirements of WAC 173-303.

Both cover designs rely on a vegetated soil system as a physical barrier over the waste and as long-term protection from moisture infiltrating the waste layer. As the two cover designs have common boundaries, integration of their design and construction is essential to minimize cost and insure compliance with environmental regulations. The slopes of both covers must be designed to control surface run-off from extreme storm events. Also, consideration must be given to the internal drainage layer of the cover over the chemical waste trenches so that collected subsurface water is not introduced to the SWL.

\subsection{PERFORMANCE STANDARDS}

This section reviews the solid waste post-closure performance standard of WAC 173-304 to demonstrate that applicable performance standards will be addressed in a comprehensive manner by the SWL interim closure strategy.

The solid waste closure performance standard of WAC 173-304-407(6) requires that the owner and/or operator perform post-closure activities to allow continued facility maintenance and monitoring of air, land, and water as long as necessary for the facility to stabilize and protect human health and the environment.

Post-closure plans contain comprehensive post-closure inspection and maintenance, and environmental monitoring programs. The inspection and maintenance plans discussed in Chapter 5.0 are designed to insure that the integrity and effectiveness of the cover, facility structures, and monitoring systems are maintained. The monitoring program consists of vadose zone and groundwater monitoring to evaluate the hydraulic performance of the operational cover and impacts to the environment. In addition to vadose zone and groundwater monitoring, the SWL post-closure monitoring program will also provide for landfill-gas monitoring because sanitary wastes can produce landfill gas from biodegradation processes. No surface water monitoring is proposed because no bodies of surface water exist in the vicinity of the landfill.

\subsubsection{Asbestos Cover Requirements}

Disposal of asbestos-containing waste is not specifically regulated under WAC 173-304; such waste is regulated under 40 CFR 61 . According to 40 CFR 61.151, cover requirements for inactive trenches that received asbestos-containing waste are to (1) cover the waste with at least 15.24 centimeters (6 inches) of compacted non-asbestoscontaining material and maintain a vegetative cover on the site or (2) cover the asbestoscontaining material with .61 meters ( 2 feet) of compacted non-asbestos-containing material 
and maintain the unvegetated surface. An operational soil cover, between $.61-$ and 1.22-meters (2- and 4-feet)- thick, is placed over each asbestos waste disposal trench at the time the trench reaches capacity, meeting the final closure requirements of 40 CFR 61 .

\subsubsection{Groundwater Monitoring Requirements}

Groundwater monitoring requirements for the SWL are found in WAC 173-304-490. A comprehensive description of the SWL groundwater monitoring program is in the Groundwater Monitoring Plan for the Solid Waste Landfill (WHC 1993).

\subsubsection{Landfill-Gas Monitoring and Control}

The overall purpose of landfill-gas monitoring is to ensure that the SWL meets regulatory requirements for managing landfill gas and adequately safeguards health and safety during each period of activity. The landfill-gas monitoring plan (DOE-RL 1993) addresses the sampling frequency, monitoring parameters, analytical method, quality control, reporting, and sample handling. Monitoring will provide information on concentrations of landfill gas that can be used to design control measures for the landfill gas (as necessary) for the closure and postclosure periods.

Typically, conditions within municipal solid waste landfills become progressively more anaerobic (favoring microbes that live without free oxygen) over time. Anaerobic microbes produce relatively more methane and less carbon dioxide in the later stages of waste fill decomposition. Aerobic bacteria produce carbon dioxide. The operational monitoring network will be used to track changes in the production of landfill gas during the interim, closure, and post-closure periods.

If continued monitoring during interim closure shows minimal changes in landfill-gas production, and methane levels do not approach or exceed the five percent limit at the property boundary, installation of vents at closure may be unnecessary. However, if significant changes are detected by the monitoring network, then one or more extraction test wells would be installed. Extraction tests would be performed to determine appropriate sizes and spacings for vent risers, and a passive vent system would be designed and constructed to conform to specific functional requirements established at that time.

\subsubsection{Maintenance Considerations}

The cover must be designed to function effectively and continuously with minimal maintenance according to WAC 173-304-407(3)(a). This section identifies provisions for minimizing maintenance during the interim closure care period. Additional information regarding interim closure inspection, monitoring, and maintenance of the "interim cover" is presented in Chapter 5.0. 


\section{DOE/RL-90-38, Rev. 1}

4.2.4.1 Wind Erosion. The principal hazard associated with wind erosion is breaching the upper part of the cover and exposing the waste. Erosion of the SWL will be controlled by the coarseness of the cover soils, minimal slopes, and the health of the vegetative cover that will develop naturally with time. Areas of the SWL that ceased activity several years ago have become vegetated with the same plant community that surrounds the landfill with the exception of a few species such as sagebrush. Surface erosion has proven to be minimal in the earlier developed units of the landfill where no special actions were taken to vegetate the cover. No additional actions appear to be necessary to prevent wind erosion.

The soil surface on the cover will require periodic inspection to verify that soil losses are generally within acceptable limits and that pronounced localized erosion does not occur. Provisions for interim closure maintenance are addressed in Chapter 5.0, Section 5.2.

4.2.4.2 Water Erosion. The potential hazards associated with water erosion are the same as those identified previously for wind. Damage from water erosion can be relatively uniform over a wide area (sheet erosion) or concentrated in a local area (gullying).

Drainage of surface water onto and off the SWL site is controlled by the site topography and the permeable nature of site soils. Run-on, run-off, and depression storage of surface water have not been experienced at the SWL at any time since the initiation of operations in 1973. These observations are consistent with the geomorphological character of the area, which lacks natural surface drainage features (e.g., rill channels, erosional gullies). Performance predictions for the "interim cover" were developed with the Hydrologic Evaluation of Landfill Performance (HELP) model (Appendix B). Modeling results indicate that under normal climatic conditions, minimal surface run-off occurs from the site because of the following attributes:

- Relatively flat surface slopes

- Permeable surface soil (sand)

- Typically low antecedent moisture conditions in the upper part of the soil column (in response to the locally high evaporation rates)

- Relatively small quantities of moisture received at the site.

4.2.4.2.1 Surface Water Control. The design standard for minimizing liquids (WAC 173-304-460[3][a]) through surface water control requires that all run-on resulting from the maximum flow of the 25 -year storm be prevented and run-off resulting from the 25-year, 24-hour storm be collected. The performance of the operational cover exposed to the 25-year, 24-hour storm was evaluated and discussed in Section 5.3.2 and Appendix 5F of the permit application (DOE-RL 1993).

The 25-year, 24-hour storm simulation predicted that 95.5 percent (all but 1.8 millimeters [ $0.071 \mathrm{inch}$ ]) of the 40 millimeters ( 1.56 inches) of precipitation received at the Hanford Site would infiltrate the "interim cover". The 1.8 millimeters $(0.071 \mathrm{inch})$ of 
1 potential runon or runoff that would occur during the day of the design storm corresponds to

2 about 18.4 kiloliters of water per hectare (260 cubic feet of water per acre) of surface.

3 Localized swales or depressions that exist outside the perimeter of the SWL can be employed

4 to collect any run-off for eventual disposal by evaporation or percolation.

Run-on from most adjacent areas is prevented from flowing onto the landfill by the topography of the SWL site. Final grading of inactive portions of the SWL has resulted in a general topography with gentle slopes down and away from the center of the SWL (Appendix A). Some portions may require a cutoff ditch to prevent any runon.

Contaminated runoff cannot be generated because the trench method is employed, and all waste is disposed of below grade. No surface water bodies exist in the vicinity of the landfill that would be affected by surface runoff from the SWL.

\subsubsection{Deeply-Rooted Plants. Deeply-rooted plants remove deeply stored soil water} (The Role of Plants and Animals in Isolation Barriers at Hanford, Washington

[Link et al. 1995]). The structure of the plant community controls the dynamics of soil moisture. Areas that have lost deeply-rooted plants to fire stored significantly more water in the deeper soils than adjacent areas unaffected by fire (Response of Shrub-Steppe Ecosystem to Fire: Soil Water and Vegetational Change [Link et al. 1990]). A number of indigenous plant species on the Hanford Site have rooting depths of 2.44 meters ( 8 feet) or more (Rooting Depth and Distributions of Deep Rooted Plants in the 200 Area Control Zone of the Hanford Site [Klepper et al. 1985]). Many of the deep-rooted species that are local to the Hanford Site are relatively slow-growing perennials (e.g., big sagebrush and rabbitbrush). At a dangerous waste landfill, there is a hazard regarding direct uptake of contaminants by plants if roots are able to reach the waste zone. However, plant uptake of contaminants is not a design issue for the SWL cover.

4.2.4.4 Burrowing Animals. Small mammals indigenous to the Hanford Site have been reported to burrow to depths of 1.8 to 2.0 meters (4.91 to 6.56 feet) (Relevance of Biotic Pathways to the Long-Term Regulation of Nuclear Waste Disposal: Phase II Final Report [McKenzie et al. 1986]; Habitat Requirements and Burrowing Depths of Rodents in Relation to Shallow Waste Burial Sites, [Gano and States 1982]). The principal indigenous rodents at the SWL are Townsend's ground squirrel (Spermophilus townsendii), Northern pocket gopher (Thomomys talpoides), and the Great Basin pocket mouse (Perognathus parvus). The deer mouse (Peromyscus maniculatus) also might inhabit the SWL vicinity, but is more prevalent at higher elevations of the Hanford Site with cooler, more rocky soils. Badgers (Taxidea taxus) prey on burrowing rodents and are capable of excavating to depths of over 2.0 meters (6.56 feet). However, incentives ordinarily are not present that would cause badgers to excavate beyond the limits of prey burrows.

According to McKenzie et al. (1986), the one animal species at the Hanford Site that routinely burrows to depths in excess of six feet is the harvester ant (Pogononyrmex owyheei). Fitzner et al. (Characterization of the Hanford 300 Area Burial Grounds, Task IV - Biological Transport [1979]) reported maximum burrow depths of 1.7 to 2.7 meters (5.58 to 8.86 feet) in excavations of five separate harvester ant colonies on the Hanford Site. McKenzie et al. indicate that about 95 percent of harvester ant burrowing is confined to the 
1 upper 2.0 meters (6.56 feet) of the soil column. Harvester ants represent specific

2 biointrusion concerns at numerous radiological waste sites. However, the hazard posed by 3 harvester ants at the SWL is viewed to be nonsignificant, insofar as the volume of soil and 4 solid waste refuse that could conceivably be disturbed by ants is quite small and the disposed 5 wastes at the SWL are nondangerous and nonradiological.

As indicated in Figure 3-2, at the conclusion of operation, trenches at the SWL received a 0.3 -meter (1-foot)- thick layer of river cobble or gravel, followed by an operational cover of local sandy soil 0.6 to 1.2 meters ( 2 to 4 feet) thick. The cobble layer provides a reasonable barrier for smaller rodents. The operational cover thickness of 1.5 meters ( 5 feet) should be sufficient to eliminate all significant issues relating to burrowing animals.

4.2.4.5 Settlement and Subsidence. Settlement and subsidence refer to vertical downward displacement of the ground surface produced by any of several mechanisms that involve dewatering (consolidation), compression, compaction, density reduction, or void formation in the subsurface. Surface and near-surface soils at the SWL consist of sands of fluvial and eolian origin. The vadose zone at the SWL is relatively thick and consists almost entirely of interbedded sands and gravels with occasional thin interbedded silts. None of these subsoil materials characteristically exhibits significant consolidation (dewatering) behavior.

Compression refers to a change in thickness of subsoils caused by the weight of cover materials placed over the site, exclusive of any consolidation effects. As no additional cover soils will be applied during the interim closure period, compression of subsoils will be minimized.

Cavities or large voids within a soil or rock mass can cause localized subsidence at the ground surface (Settlement and Cover Subsidence of Hazardous Waste Landfills [EPA 1985]). Cavity-related subsidence has been documented related to mining, karst (solution cavity) areas, and landfills. No mining activities have occurred at the SWL. No water-soluble rock (such as limestone, which frequently contains solution cavities) exists beneath the site to a depth of several thousand feet. Cavity-related subsidence in landfills can be caused by dewatering of waste, decomposition of organic waste, and coalescence of smaller voids created by random, loose placement of waste. These processes can produce cracks, shearing displacements, and ponding of water in depressions formed by uneven subsidence within the waste layer beneath the cover. Some cavity-related subsidence is possible at the SWL.

Over time, some perceptible amount of subsidence ordinarily is anticipated at a closed municipal landfill as a result of the continuing biodegradation of municipal-type solid wastes. Biodegradation reduces the mass of the waste allowing subsidence by increasing the density and reducing the volume within the waste-fill zone. At locations with arid and semiarid climates (such as the Hanford Site), biodegradation of solid waste may proceed relatively slowly because water is not present in sufficient quantities to facilitate the process. At such sites, the rate of volume change within the waste zone may be quite low. 
During the interim closure care period, surface elevations will be monitored to detect subsidence and long-term soil loss. If localized subsidence is detected during the interim closure care period, additional soil will be placed over the affected area to prevent ponding and to return the surface to the designed final grade. Because the soil layer performs all moisture removal, this would be the only necessary remedial action.

4.2.4.6 Seismic Events. The principal hazard from seismic events (earthquakes) relates to particle accelerations at the ground surface. Breaching by faulting is not considered to be a significant risk in that no major faults have been identified at the SWL, and only one fault on the Hanford Site (located at Gable Mountain) shows evidence of movement within the past 13,000 years (DOE 1988).

Historically, seismic activity at the Hanford Site has been low, and the probability of exceeding even the relatively low acceleration value of $0.05 \mathrm{~g}$ 's $(0.5$ meter [1.6 feet] per second squared) is reported to be only 0.002 per year at the Washington Public Power Supply System No. 2 generating plant (Proceedings of DOE Natural Phenomena Hazards Mitigation Conference [Youngs et al. 1985]). Consequently, the risk of seismically induced damage to the proposed cover for the SWL is considered to be quite small.

\subsection{INTERIM CLOSURE STRATEGY}

A description of the "interim cover" (which was the operational cover during operation of the SWL) is provided in the following sections. Cover performance information and a site water-balance calculation are also provided.

\subsubsection{Interim Cover}

At the time the trenches ceased operation, an operational fill consisting of 0.6 to 1.2 meters ( 2 to 4 feet) of native sand (Figure 3-2) was placed over the waste. The cover materials were taken from stockpiled soils and placed with bulldozers. The operational fill serves as an "interim cover" and functions to perform the following:

- Minimize vector breeding areas and animal attraction

- Provide an aesthetically pleasing appearance

- Prevent the accumulation and/or the contamination of surface water

- Reduce percolation of precipitation into the waste layer

- Vent landfill gases.

The native soil used for the "interim cover" consists of a grey, well-graded sand with a very low percentage of fines (DOE-RL 1993). This soil has engineering properties that serve to control run-off by facilitating the infiltration and storage of precipitation (Section 4.3.2). The stored moisture is removed by evaporative mechanisms (Section 4.3.1.2). The partially saturated soil allows for the vertical migration of landfill gas (Section 4.3.3). 
1 4.3.1.1 Cover Performance Requirements. The applicable minimum design standards for 2 the closure of solid waste landfills per WAC 173-304-460(3)(e) require a design for a cover 3 that will meet the following requirements:

(i) At least .61 meter ( 2 feet) of $1 \times 10^{-5}$ centimeters per second or lower permeability soil or equivalent shall be placed upon the final lifts in arid regions.

(ii) The grade of the surface slopes shall not be less than 2 percent nor the grade of the side slopes more than 33 percent.

(iii) Final cover of at least 15.24 centimeters (6 inches) of topsoil shall be placed over the soil cover and seeded with grass, other shallow rooted vegetation, or other native vegetation.

4.3.1.2 Cover Performance. In relation to water balance performance, the "interim cover" of the SWL was assessed using the Hydrologic Evaluation of Landfill Performance (HELP) Model (Schroeder et al. 1994). As the SWL is an unlined landfill with no barrier soils, membranes, or leachate collection systems to restrict the downward migration of soil water, the model was used to evaluate only the cover. Once soil moisture equilibrium is obtained, any water entering the soils and waste below the evaporative depth $(0.8$ meter [ 32 inches] with vegetation present) would eventually drain through the landfill. By modeling only the cover, fewer assumptions about the initial moisture content, field capacity, etc. of the lower portions of the landfill have to be made in setting up the model, while the results still represent leachate generation potential. The site was modeled for several conditions:

- Bare operational cover consisting of coarse sand

- Bare operational cover consisting of medium sand

- Naturally vegetated surface on a coarse sand operational cover

- Naturally vegetated surface on a medium sand operational cover.

Data for the material properties of the sand at the SWL were taken from an earlier report (DOE-RL 1993). The size distribution curve identifies a coarse sand. As finer sand, and even silt lenses are located throughout the SWL profile, the mixing of the soil during the excavation process would most likely produce a medium or finer sandy soil for the operational cover in some areas. The modeling of the medium sand operational cover was performed to indicate the degree of conservatism in the coarse sand model.

Each of the above conditions were modeled using HELP model soil property defaults:

- Bare operational cover, coarse sand. A 1.2-meter (48-inch)-thick layer of coarse sand modeled as a vertical percolation layer with 0.417 porosity, 0.045 field capacity, 0.018 wilting point, and an effective hydraulic conductivity value of $1.0 \times 10^{-2}$ centimeters per second (HELP model material texture number 1). The surface was modeled as 'bare ground', with the evaporative depth set at 0.4 meter (16 inches) (default value for bare ground in Yakima, Washington). 
- Bare operational cover, medium sand. A 1.2-meter (48-inch)-thick layer of medium sand modeled as a vertical percolation layer with 0.437 porosity, 0.062 field capacity, 0.024 wilting point, and an effective hydraulic conductivity value of $5.8 \times 10^{-3}$ centimeters per second (HELP model material texture number 2). The surface was modeled as 'bare ground', with the evaporative depth set at 0.4 meter (16 inches).

- Vegetated operational cover, coarse sand. Same material properties as the coarse sand bare operational cover above (HELP model material texture number 1) with a maximum leaf area index of 1.6 and evaporative depth set at 0.8 meter (32 inches) (default values for Yakima, Washington).

- Vegetated operational cover, medium sand. Same material properties as the medium sand bare operational cover above (HELP model material texture number 2) with a maximum leaf area index of 1.6 and evaporative depth set at 0.8 meter (32 inches) (default values for Yakima, Washington).

Climatological data, including daily temperatures, daily precipitation, daily solar radiation, quarterly humidity values, average wind speed, etc., were obtained from reports from the Hanford Meteorology Station. In the analysis, the SWL site was subjected to 169 millimeters (6.67 inches) of average annual precipitation, using actual Hanford Site data for the period 1970 to 1994 (25 years). The long-term average value for the Hanford Site is 159 millimeters (6.26 inches), based on precipitation measurements taken from 1946 to 1994 . Initial soil moisture content was selected through an iterative process in an effort to start the model with the cover soil at equilibrium over the 25 year period. The output reports for the model simulations (with monthly summaries) are included as Appendix B.

Under quasi-steady state conditions, the model predicted 22 millimeters $(0.87$ inch) of leachate production of drainage per year for the bare coarse sand cover (about 22.2 liters of drainage per year per square meter ( 0.073 cubic foot of drainage per year per square foot]) of surface area or an average conductivity of $0.7 \times 10^{7} \mathrm{~cm} / \mathrm{sec}$ for the 25 -year period. For the vegetated coarse sand cover, the model predicted 17 millimeters $(0.67$ inch) of leachate production per year (about 17 liters per year per square meter $[0.056$ cubic foot per year per square foot] or an average conductivity of $0.5 \times 10^{-7} \mathrm{~cm} / \mathrm{sec}$ ) for the 25 -year period. Within this period, run-off was limited to extreme events or snow melt conditions and averaged 1.4 percent of the annual precipitation for the bare cover and less than 1 percent when grass was present. In the model simulation, annual evapotranspiration (expressed as a percent of annual precipitation receipts at the Hanford Site) ranged from a low of 57.1 percent (bare cover) to a high of 125.9 percent (vegetated cover). On the average, evaporation accounted for 85.5 to 89 percent of precipitation receipts.

The HELP model does not consider deeply rooted plants in the calculations for areas of poor vegetative cover. Therefore, the results for evapotranspiration are conservative compared to what would occur once native vegetation was reestablished. 


\subsubsection{Landfill Gas Control}

The primary purpose of the gas control system was to protect landfill operators and other Hanford Site personnel from the hazards associated with the accumulation of landfill gas (specifically methane). Hanford Site security measures (Section 4.6) and the remote location of the SWL site protect the general public from potential landfill gas hazards.

Methane and carbon dioxide are the principal components of landfill gas. Methane is generated by the natural decomposition of putrescible waste in the absence of oxygen. With a density less than air, methane is combustible and explosive at concentrations from 5 to 15 percent by volume in air under normal atmospheric conditions. The minimum functional standards for air quality (WAC 173-304-460[2][b][i]) prohibit methane concentrations from exceeding the lower explosive limit at the boundary or beyond the landfill. The regulations also require that the concentration of methane not exceed 25 percent of the lower explosive limit in onsite facility structures or 100 parts per million by volume in offsite structures. A landfill gas monitoring network is described in Section 4.4.3 to assess gas concentrations in the subsurface and within structures on the SWL site to demonstrate compliance with performance standards.

Existing information indicates that methane production is relatively low and well below the performance standard. Dry climatological conditions with high evapotranspiration potential, low soil moisture conditions, and water balance studies (DOE-RL 1993) indicate that relatively little moisture accumulates in the waste zone to facilitate biodegradation and the production of methane in the landfill. Though some silt layers are near saturation, the moisture would not be released to the waste trench because of the pore pressure. In addition, the types of wastes typically disposed of at the SWL contain very little putrescible waste (except for the sewage trenches which account for about one percent of the total volume of the landfill) and expected aerobic conditions are not conducive to high methane production. Data from a 1988 near-surface soil-gas study of the SWL show a mean methane concentration of 6.5 parts per million with a standard deviation of 11.2 parts per million and a range up to 83 parts per million. Methane concentrations in soil gas located in the near subsurface within the Phase II area of the landfill are substantially less than the lower explosive limit for methane ( 5 percent or 50,000 parts per million). Soil gas measured outside the landfill boundary contains less than 3 parts per million of methane. The expected aerobic conditions are confirmed by the high concentrations of carbon dioxide that have been reported by all soil gas surveys at the SWL. An interpretation of the data is provided in Chapter 5.0, Section 5.7 of the permit application (DOE-RL 1993).

According to WAC 173-304-460(3)(f), landfills handling more than 7646 cubic meters $(10,000$ cubic yards) of waste per year are required to continuously collect landfill gas and either purify it for sale, flare it, or use it for energy. Because the production of methane and other gases is expected to be below levels that are able to support combustion, the collection and handling of landfill gas is not required (WAC 173-304-460[3][f][ii]). However, the installation of vents is required. 
The daily and operational covers consist of relatively loose, porous sand which is expected to provide a preferential vertical path for gas releases into the air (i.e., vent any gas). This will limit the accumulation of gas within the landfill and minimize lateral movement and the potential for gas to migrate beyond the SWL boundary. Methane is expected to escape upward easily. If lateral migration does occur, no hazard is expected to develop in offsite structures because the nearest offsite structure is a trailer located near the 200 East Area, approximately 5.6 kilometers ( 3.5 miles) away. Typically, landfill gas does not travel laterally in the subsurface more than 150 to 300 meters (500 to 1,000 feet) (Solid Waste Landfill Design Manual [Parametrix 1987]). No monitoring of offsite structures is planned.

Landfill gas production at the SWL is expected to continue to be minor. If monitoring activities indicate that gas concentrations violate or could be expected to violate the performance standards, a corrective action program will be initiated. The corrective action plan will be prepared to evaluate alternative corrective measures, such as a perimeter gas extraction system or an enhanced landfill ventilation system. The final corrective action would be selected with the concurrence of Ecology.

\subsubsection{Litter Control}

Once the landfill ceases operations, the potential to generate litter will be eliminated. All previously scattered litter will be collected in preparation for the interim closure period.

The 2.4-meter (8-foot)-tall fence that surrounds the perimeter of the SWL will remain in place during the interim period prior to final closure. Material collected by the fence during the interim (predicted to be predominately tumble weeds) will be collected.

\subsubsection{Vector Control}

Vector, as defined by WAC 173-304-100(85), means living animals that transmit infectious diseases. Vectors typically include rodents, insects and other arthropods, and birds. These animals are attracted to landfills as a source of food and shelter especially when the waste is not covered. Potential food sources are only a small percentage of the waste in the SWL. When operations cease at the SWL with all trenches covered under 0.6 to 1.2 meters ( 24 to 48 inches) of soil, vectors will no longer be a concern.

\subsubsection{Dust Control}

The soils at the SWL are relatively coarse, and dust is usually not a problem unless high winds develop. Because of the remote location, dust generated from the bare cover would not affect structures or personnel off the SWL site. 


\subsection{ENVIRONMENTAL MONITORING}

The environmental monitoring program at the SWL includes sampling the groundwater, vadose zone, and landfill gas. The objectives of the environmental monitoring program are:

- Comply with the monitoring standards of WAC 173-304

- Detect contaminants originating from the SWL and assess the nature and extent of any contamination

- Ensure that methane concentrations do not pose a safety risk

- Protect the environment, and employee and public health and safety.

The SWL groundwater monitoring program, which was initiated in 1987 , is summarized in Section 4.4.1. Data collected to assess groundwater quality are available in Appendices 5C and 5D of the permit application (DOE-RL 1993) and are tabulated in RCRA annual reports for the Hanford Site. Vadose zone and landfill gas monitoring programs are described in Sections 4.4.2 and 4.4.3, respectively. Surface water monitoring is not provided because surface waters do not exist in the vicinity of the SWL.

\subsubsection{Groundwater Monitoring}

This section summarizes the groundwater monitoring program which has been designed to comply with WAC $173-304-490$. Complete monitoring plans providing detailed information on sampling techniques, frequency, handling, monitoring parameters, analytical methods, data analysis procedures, and quality assurance and quality control are in the groundwater monitoring plan (WHC 1993).

The following are the objectives of the groundwater monitoring program:

- Comply with the requirements of WAC 173-304-460 and WAC 173-304-490

- Determine if the landfill is affecting groundwater at the point of compliance.

4.4.1.1 Monitoring Network. The existing monitoring network consists of two upgradient wells on the west side of the SWL (Well 699-26-35A is shared with the NRDWL) and seven downgradient wells along the east and south sides of the SWL (Hodges 1994). A construction diagram for a typical SWL well is in Figure 4-1. The existing wells were constructed in compliance with RCRA and the requirements of WAC 173-160 (WAC 173-304-490[2][b]).

Five of the downgradient wells were originally constructed on the basis of the regional groundwater flow direction, which is roughly perpendicular to the long axis of the SWL 
1 (north-south). However, further evaluation of the flow direction based on the movement of

2200 Area nitrate and tritium plumes passing in the groundwater beneath the SWL indicates a

3 flow direction between 130 degrees and 140 degrees east of north. Two additional

4 groundwater monitoring wells were installed in 1993 to complete the downgradient

4.4.1.2 Sampling and Analysis. The sampling and analysis of groundwater is described in the groundwater monitoring plan (WHC 1993). This plan contains or references procedures for decontamination of drilling and sampling equipment, sample collection, sample preservation and shipment, analytical procedures and quality assurance, chain-of-custody control, and employee health and safety during well installation and monitoring (WAC 173-304-490[2][c]).

4.4.1.3 Constituent List. The constituent list for groundwater at the SWL includes the constituents required by WAC 173-304-490(2)(d) listed in Table 4-3 with some additions. Total alpha, tritium, and total beta contents are analyzed to aid in determining groundwater flow rates and directions, but these are not considered site-specific parameters and will not be statistically evaluated.

4.4.1.4 Sampling Frequency. Wells in the SWL monitoring network are sampled quarterly as required by WAC $173-304-490(2)(\mathrm{g})$.

4.4.1.5 Data Analysis. The methods for establishing background values and statistically evaluating groundwater chemistry data, as required by WAC 173-304-490(2)(f), are discussed in detail in the groundwater monitoring plan (WHC 1993).

4.4.1.6 Direction and Rate of Groundwater Flow. Measurements of water table elevation and the distribution of contaminants in plumes originating from the 200 Areas are used to determine the direction of groundwater flow. Measurements of the water table elevation are currently taken on a monthly schedule.

\subsubsection{Reports and Notifications.}

4.4.1.7.1 Annual Report. The DOE-RL submits an annual report that includes all determinations of water table elevations in monitoring wells, a determination of the rate and direction of groundwater flow, all analytical data for samples from monitoring wells, and statistical evaluations of all data from monitoring wells.

4.4.1.7.2 Notifications of Groundwater Contamination. If there is a statistically significant increase for any parameter or constituent in any well at the compliance point, the following will occur.

- The DOE-RL will notify Ecology in writing within seven days of receipt of the sampling data, indicating what parameters or constituents have shown statistically significant increases (WAC 173-304-490[2][i][i]). 
- All monitoring wells will be resampled immediately and analyzed for the constituents listed in WAC 173-304-100 and for any additional constituents required to determine whether there has been a statistically significant increase (WAC 173-304-490[2][i][ii]).

- The DOE-RL will notify Ecology of the results of the resampling effort within 14 days of receipt of the data (WAC 173-304-490[2][i][ii]).

4.4.1.8 Corrective Action. If Ecology determines that corrective action is required, a corrective action plan will be prepared and submitted to Ecology for review and approval. In accordance with this, a corrective action plan (Hodges 1994) was submitted to Ecology in December 1994 which was subsequently approved in June 1995. This document is a guide to remedial activities at the SWL (Ecology letter of November 20, 1995 from Fenggang Ma to James E. Rasmussen, DOE-RL).

\subsubsection{Vadose Zone Monitoring}

This section describes the vadose zone monitoring program which complies with the arid design standard of WAC 173-304-460(3)(c)(iv). Specific aspects of the vadose zone monitoring program are based on Ecology's guidance for vadose zone monitoring at sanitary landfills (Ecology 1989) and technical guidance provided in Ecology's Solid Waste Landfill Design Manual (Parametrix 1987). The vadose zone monitoring plan for the SWL is in Appendix 5H of the landfill permit application (DOE-RL 1993). This plan describes the proposed monitoring system, including monitoring locations, the sampling and chemical analysis plan, a method for analyzing monitoring data, and a quality assurance plan.

The arid design standard permits monitoring moisture in the vadose zone in lieu of a liner for solid waste landfills in arid locations where the average annual precipitation is less than 300 millimeters (12 inches) and the depth to groundwater is greater that 3 meters (10 feet) beneath the waste. With an average annual precipitation of 159 millimeters (6.26 inches) and a water table more than 30 meters (100 feet) beneath the waste, the SWL qualifies for the option of vadose zone monitoring.

The objective of monitoring the vadose zone is early detection of any leachate generated in volumes and concentrations that could contaminate the groundwater beyond the point of compliance. A lysimeter is used to monitor the vadose zone. The lysimeter can be used to evaluate the hydrologic performance of the "interim cover" and the stabilization of the waste.

4.4.2.1 Monitoring Network. The vadose zone monitoring system consists of a large basin lysimeter located in the Phase II area of the SWL. A basin lysimeter is a lined basin in the soil beneath one trench that functions as a large-scale sampling device for leachate (Figure 4-3). Specific design information is provided in Appendix 5H of the permit application (DOE-RL 1993). Any leachate generated by natural precipitation percolating 
1 through the waste layer is collected by the basin lysimeter. A collection pipe connected to

2 the lysimeter allows any leachate to drain into a collection sump that contains the necessary

3 sampling equipment. The chemistry of the leachate will be evaluated and the volume of

4 leachate leaving the landfill will be determined. The lysimeter began operating in June 1992,

5 and no leachate has collected in the sump as of February 1996.

4.4.2.2 Sampling and Analysis. A sampling procedure developed to obtain samples that represent the quantity and quality of leachate percolating through the SWL is described in the vadose zone monitoring plan in the landfill permit application (DOE-RL 1993).

4.4.2.3 Sampling Frequency. Leachate samples for indicator parameters will be collected from the lysimeter at least quarterly, if any leachate appears. At present, the system is

\subsubsection{Landfill Gas Monitoring}

This section describes the landfill gas monitoring program to demonstrate compliance with the air quality performance standards of WAC 173-304-460(2)(b). Specific aspects of the program are based on technical guidance provided in Ecology's Solid Waste Landfill Design Manual (Parametrix 1987). Landfill gas monitoring at the SWL is controlled by the landfill gas monitoring plan Appendix 5I of the landfill permit application (DOE-RL 1993).

The standards of performance for gas prohibit concentrations of methane gas from exceeding 1.25 percent by volume in facility structures, 5 percent by volume at the facility boundary, and 100 parts per million by volume in offsite structures. Because offsite structures in the vicinity of the SWL are nonexistent and none are planned, the last standard is not addressed further. Specific objectives of subsurface landfill gas monitoring are as follows:

- Periodically measure landfill gas composition along the perimeter of the landfill

- Monitor methane concentrations in enclosed onsite structures

- Monitor landfill gas production to evaluate waste stabilization during the postclosure period. plans.

Information from monitoring will be used to support final closure and postclosure

4.4.3.1 Monitoring Network. The SWL landfill gas monitoring program considers both the generation of subsurface gas and the accumulation of gas in onsite structures. The subsurface monitoring system consists of eight shallow monitoring stations located around the perimeter of the SWL. Each monitoring station consists of two dedicated soil-gas probes driven to depths of approximately 2.7 and 4.6 meters ( 9 and 15 feet) below the ground 
1 surface. Each probe consists of a stainless steel point connected to 6-millimeter 2 ( $1 / 4$-inch)-diameter Teflon ${ }^{2}$ tubing.

3

\subsubsection{Record Keeping}

Operating records, maintained by the operations and engineering contractor, include:

- Waste placement plan

- Daily operating logs

- Weekly inspection logs

- Monthly waste summary logs

- Environmental monitoring data

- Solid waste disposal requests

- Onsite waste tracking forms.

The waste placement plan (Figure 3-1) identifies actual dates that trenches were filled.

\footnotetext{
${ }^{2}$ Teflon is a trademark of E.I. DuPont de Nemours \& Company.
} 
1 4.5.1.2 Inspection Records. Inspections of the SWL will be made quarterly by landfill

2 management. Inspection information recorded will include the following:

- Date and time of inspection

- Inspector's printed name and handwritten signature

- Notations of observations

- Date and nature of any repairs or other corrective actions.

Inspection records are maintained at the landfill management office for a period of three years following the inspection date.

4.5.1.3 Environmental Monitoring Data. The environmental monitoring program currently consists of a quarterly sampling program for groundwater quality as described in Chapter 5 of the permit application (DOE-RL 1993). Monitoring records include analytical results from samples sent to offsite laboratories for chemical analysis, field data, and data analyses. Field notebooks will be used to record field measurements.

Groundwater monitoring records stored in the Hanford Environmental Information System (HEIS) (managed by the Environmental Restoration Contract team) and Geosciences Data Analysis Toolkit (GEODAT) (a database managed by Hanford Technical Services of WHC) include the following:

- Results from laboratory chemical analyses of quarterly groundwater samples, including samples to assess the quality of the groundwater

- Field measurements of the water table to assess groundwater flow rate and direction.

Vadose zone monitoring records will include the following:

- Laboratory chemical analyses of any collected leachate

- Field measurements of leachate quantity

- Mathematical analyses to determine impacts on groundwater quality.

Landfill gas measurements will include field measurements of landfill gas composition and instrument calibration information.

Environmental monitoring data will be maintained by the Groundwater Management group of WHC or whoever replaces them for the duration of the interim and postclosure life of the SWL. If it becomes necessary to implement a corrective action program, the records of the programs will also be maintained by landfill management. 


\subsubsection{Reporting Requirements}

This section describes the reports that are required as part of interim closure care and those required when monitored parameters or constituents are determined to be present at significantly increased levels.

4.5.2.1 Annual Reports. An annual report that includes the following information will be submitted to Ecology by March 1 of each year:

- Name and address of the SWL

- Calendar year covered by the report

- Results of the environmental monitoring program, including the following:

- Water level determinations

- Rate and direction of groundwater flow

- Analytical data for samples collected from groundwater monitoring wells, lysimeter sumps, and landfill gas monitoring wells

- Statistical evaluations of groundwater and lysimeter data.

4.5.2.2 Notifications. If it is determined that there is a statistically significant increase for a parameter or constituent at any groundwater monitoring well at the compliance point, Ecology will be notified in writing of the finding within seven days of receipt of the sampling data. The notification will indicate which parameters have shown statistically significant increases. Resampling will be required in this case, and Ecology will be notified of the results of the resampling within fourteen days of the receipt of the analytical results.

\subsection{SECURITY INFORMATION}

An effective security program is maintained at the Hanford Site because of the nature of ongoing activities and the presence of several units that handle dangerous and radioactive materials. Security systems on the Hanford Site prevent unknowing entry and minimize the possibility for unauthorized entry of persons or livestock into the SWL.

Unauthorized or unintended entry to the SWL is prevented by 24-hour staffed barricades on roads leading to the SWL. The SWL is surrounded by an 2.45 -meter ( 8 -foot)-high perimeter fence bearing appropriate signs. The several gates in this fence are normally locked.

The operations office trailer is located adjacent to the southeast SWL entrance gate. It will remain during the interim closure period to provide short term record and material storage for the maintenance and monitoring of the SWL. 
DOE/RL-90-38, Rev. 1

1

2 4.7 AMENDMENT OF PLAN

3

4 If an amendment to the approved interim closure plan is required, the DOE-RL will

5 submit a written request to Ecology to authorize a change to the approved plan. The written

6 request will include a copy of the interim closure plan amendment for approval. The

7 DOE-RL will notify Ecology of the date when the SWL site closure activities are to begin. 
DOE/RL-90-38, Rev. 1

1

2

3

4

This page intentionally left blank. 


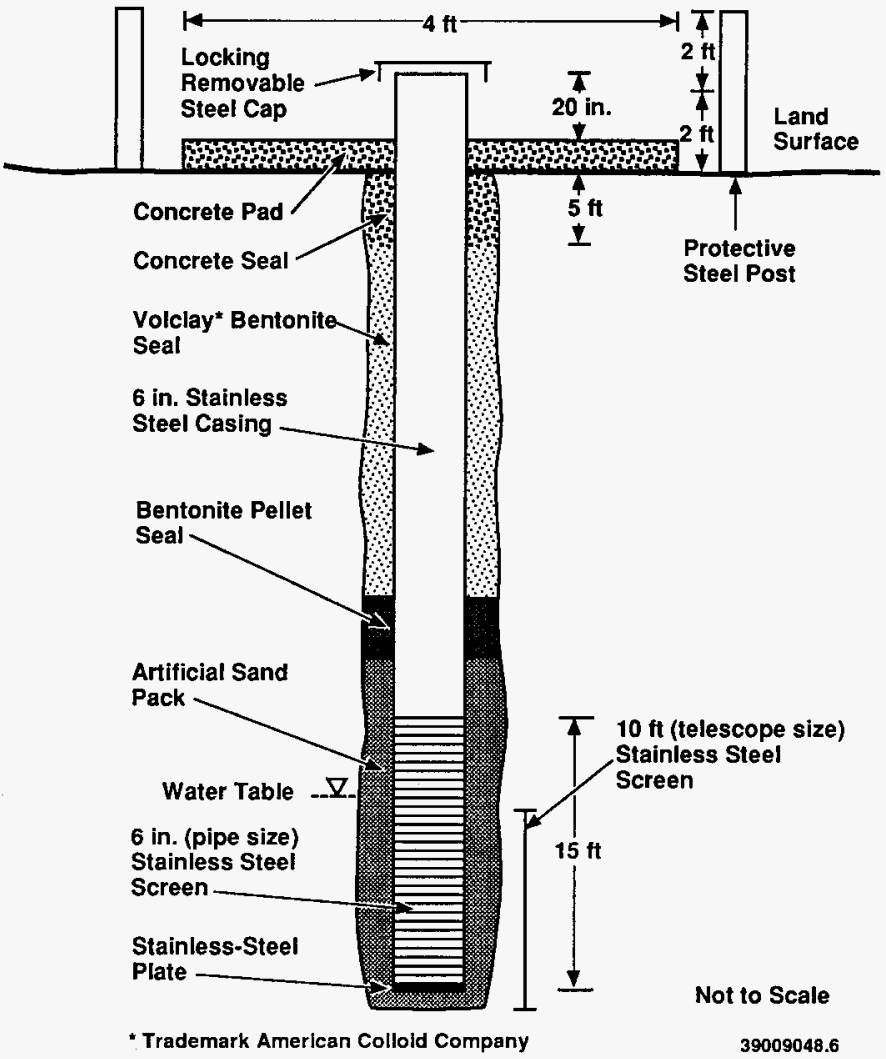

Figure 4-1. Construction Diagram for a Typical Groundwater Monitoring Well at the Solid Waste Landfill. 
DOE/RL-90-38, Rev. 1

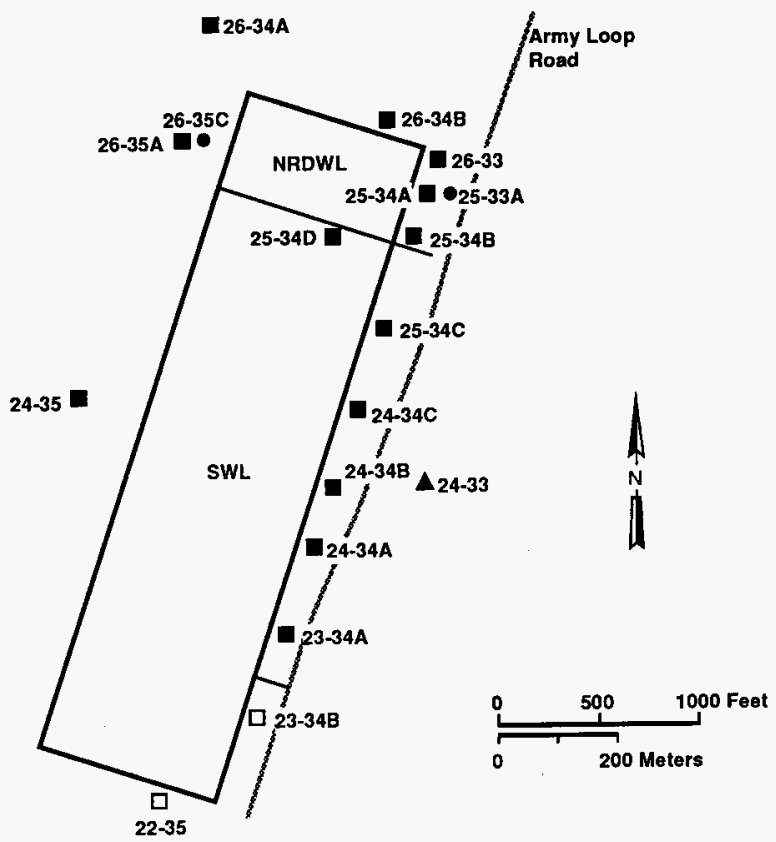

Well completed at the top of the unconfined aquifer

- Well completed in the upper Ringold Formation

A Well not constructed to RCRA specifications

D RCRA wells completed in late 1993.

NRDWL Nonradioactive Dangerous Waste Landfill

SWL Solid Waste Landfill

All wells prefixed by 699 -

H9402006.24

Figure 4-2. Map of the Solid Waste and Nonradioactive Dangerous Waste Landfills Showing the Groundwater Monitoring Wells. 


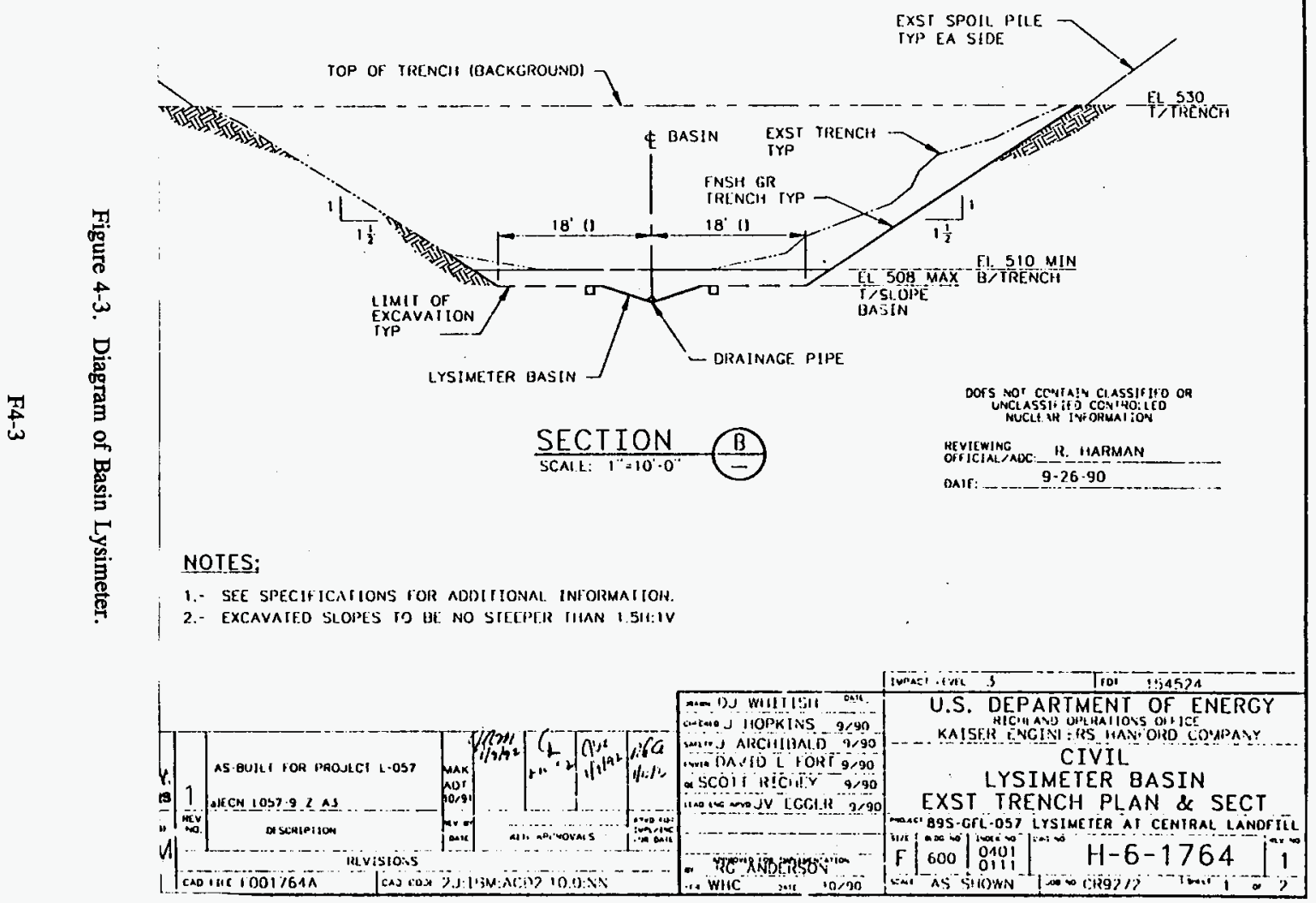


DOE/RL-90-38, Rev. 1

1

2

3

4

This page intentionally left blank. 

DOE/RL-90-38, Rev. 1

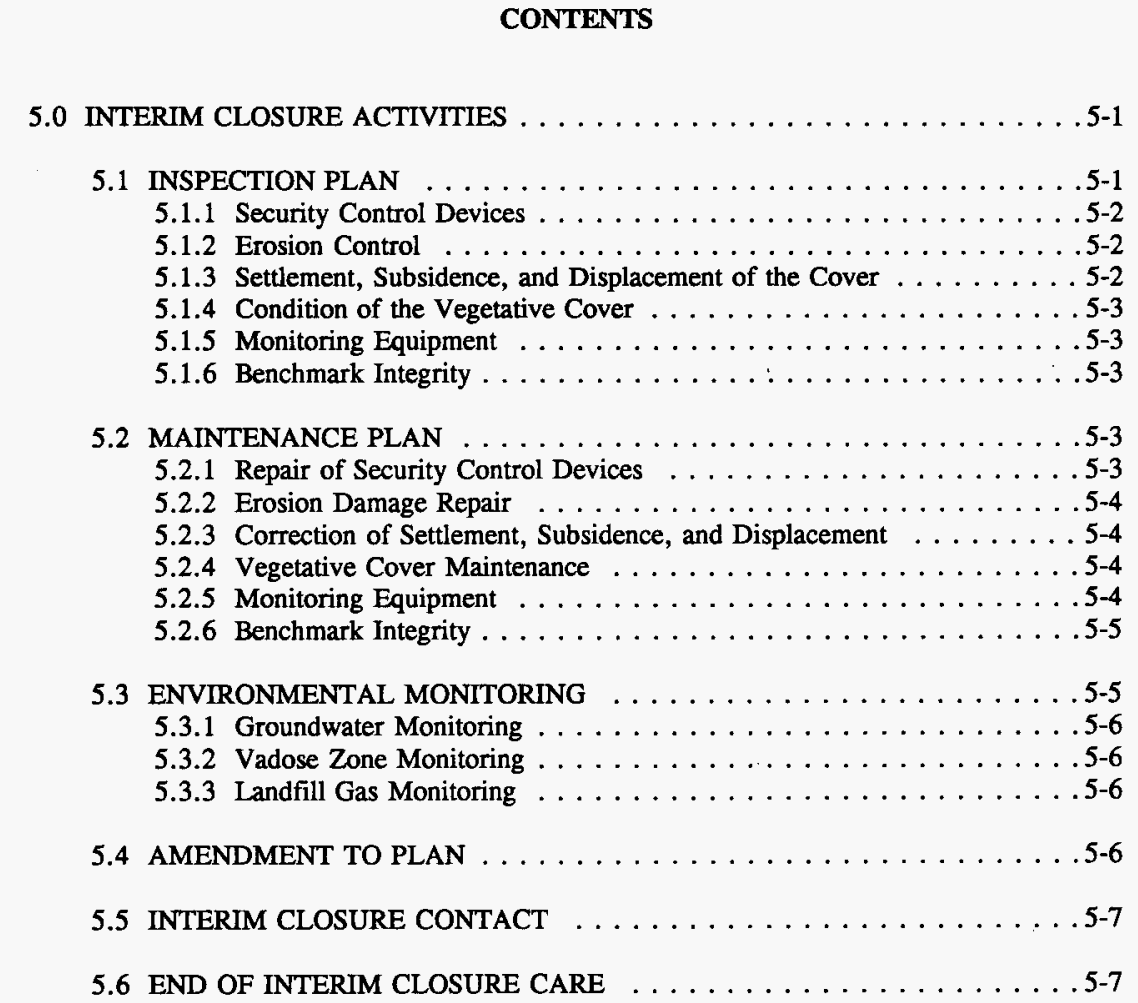

32

33

34

35

36

37

38 5-1 Inspection Schedule for the Solid Waste Landfill $\ldots \ldots \ldots \ldots \ldots \ldots \ldots$ T5-1

39

\section{TABLE}


DOE/RL-90-38, Rev. 1

$$
\begin{aligned}
& 1 \\
& 2 \\
& 3 \\
& 4 \\
& 5
\end{aligned}
$$$$
2
$$

This page intentionally left blank. 


\subsection{INTERIM CLOSURE ACTIVITIES}

This chapter describes the planned interim closure activities for the SWL. Interim closure care will satisfy the requirements to protect human health and the environment for a facility that has not undergone final closure.

The post-closure performance standards of WAC 173-304-610(2)(a) require that the owner and/or operator provide post-closure activities which promote continued maintenance of the facility and the monitoring of air, land, and water as long as necessary for the facility to stabilize and protect human health and the environment. The SWL interim closure care program will perform similarly and consists of an inspection and maintenance program described in Sections 5.1 and 5.2, as well as an environmental monitoring program described in Section 5.3. The fence and locked gates will remain in place during this interim care.

The inspection and maintenance plans are designed to insure that the integrity and effectiveness of the "interim cover" (which was the operational cover during operations), SWL site structures, and monitoring systems are maintained. The interim closure environmental monitoring program is a continuation of the operational monitoring program, consisting of landfill gas, vadose zone, and groundwater monitoring to evaluate impacts to the environment. The vadose zone monitoring program also will serve to evaluate the hydrologic performance of the "interim cover". Because no surface water bodies exist in the vicinity of the landfill that would be impacted by the landfill, no surface water monitoring is planned.

\subsection{INSPECTION PLAN}

This section describes the inspection plan for the necessary security equipment, the "interim cover" (i.e., the cover over all of the trenches during the interim closure period), monitoring equipment, and benchmark integrity. A logbook will be kept by personnel conducting the inspections and will be maintained for examination by the regulatory agency. The inspector will record any damage to the cover, structures, or equipment and will record the weather conditions at the time of inspection. The inspector will sign and date the logbook. Maintenance actions, as initiated by the logbook, will be started and completed within 90 days so that the next logbook entry can document the correction of the problem. Table 5-1 depicts the inspection items and the inspection frequency for the interim closure care period.

Run-on and run-off damage is expected to be minimal at the SWL because of the dry climatic conditions, the geometry of the site, and the hydraulic properties of the operational cover and surrounding native soil. The "interim cover" will slope to drain extreme storm events, with the average slope approaching two percent. A perimeter ditch or localized depression outside the landfill boundary will provide for surface drainage and prevent any external run-on. 


\subsubsection{Security Control Devices}

The SWL is located within a controlled access area on the Hanford Site (no unauthorized personnel are allowed). Access from the Columbia River is restricted by federal warning signs. The landfill area is patrolled by Hanford Site security personnel. The SWL is surrounded by a fence 2.4 meters ( 8 feet) tall with locked gates and warning signs. The fence, locks, and warning signs will be inspected quarterly for damage.

Monitoring wells that are located outside the SWL fence have locking caps to prevent tampering. The wells are surrounded by four steel guard posts to prevent damage from vehicles. The overall well condition, locks, guard posts, and pumps will be inspected during each sampling event. Problems or damage will be noted on the sampling log and tracked so that repairs can be made.

\subsubsection{Erosion Control}

Erosion at the SWL will be controlled by the coarseness of the cover soils, minimal slopes, and the health of the vegetative cover that will develop with time. Areas of the SWL that ceased activity several years ago have become vegetated with the same plant community that surrounds the landfill with the exception of a few species such as sagebrush. Surface erosion has proven to be minimal in the earlier developed units of the landfill. Quarterly surveys are scheduled to observe the SWL site and vegetative cover during different seasonal conditions and to insure that no appreciable erosion has taken place. The inspection will consist of a visual check of the SWL site for erosional damage.

\subsubsection{Settlement, Subsidence, and Displacement of the Cover}

Settlement, subsidence, and displacement (often expressed by any breach or depression on the exterior of the cover) are caused primarily by the deformation or compression of waste products, fill soils, and voids. Careful placement and compaction of the "interim cover" will greatly reduce the occurrence of soil settlement. A small (but perceptible) amount of subsidence is expected as the result of ongoing biodegradation processes within the waste layer. The SWL cover will be visually inspected quarterly for settlement, subsidence, and displacement. Any breaches or depressions will be investigated to determine the cause, evaluate the long-term environmental impacts, and provide a solution. Surveys are scheduled quarterly to observe the SWL during different seasonal conditions. Settlement and subsidence will be evaluated by periodically surveying the elevations of control points. 


\subsubsection{Condition of the Vegetative Cover}

The development and condition of the vegetation will be visually inspected. These inspections are scheduled quarterly to observe the site and vegetative cover during the different seasonal conditions. The vegetative cover will be inspected according to the same procedures outlined for erosional damage.

\subsubsection{Monitoring Equipment}

Groundwater monitoring wells will be inspected according to the Environmental Investigations and Site Characterization Manual (WHC 1988).

Vadose zone monitoring equipment and landfill gas monitoring wells will be inspected quarterly and each time samples are taken. The collection lysimeter drainage pipe also will be inspected. During the operational phase, the collection lysimeter was checked on a daily basis, since operational personnel were available to perform this function (Section 4.4.2.3). To date, no leachate has been collected from the lysimeter.

\subsubsection{Benchmark Integrity}

Benchmarks will be surveyed annually. The standard practice is to use two or more benchmarks to cross-check the integrity of survey measurements. Additional benchmarks will be added if needed.

\subsection{MAINTENANCE PLAN}

This section contains a plan for the maintenance of the SWL site during the interim closure period. Elements of this maintenance plan include repairing security devices; protecting the cover from erosional and fire damage; repairing damage from settlement, subsidence, and/or displacement; maintaining the vegetative cover; and replacing monitoring equipment. The maintenance plan is based on observations that will be made during inspection (Section 5.1) and monitoring (Section 5.3).

\subsubsection{Repair of Security Control Devices}

Security control devices for the SWL, including the 2.4-meter (8-foot) tall fence, locked gates, and warning signs, will be inspected for damage. Any unauthorized access will result in the immediate notification of the Hanford Site security forces. Damages identified during inspections will be reported to the responsible maintenance organization. The responsible maintenance organization will be notified of any problems to the locks or guard posts and 
other problems noted during inspections and monitoring activities. Necessary repairs will be made before the following inspection period and will be noted in the logbook during the subsequent inspection.

\subsubsection{Erosion Damage Repair}

Erosion damage will be properly noted and reported to the responsible maintenance organization. Minor damage will be repaired with hand tools. Major erosion damage will be repaired immediately using, as appropriate, grading equipment and fill soils. Repairs will be initiated within 90 days from the time of inspection and discovery. Repairs will return all site surfaces to predamaged conditions.

\subsubsection{Correction of Settlement, Subsidence, and Displacement}

Because the waste layer at the SWL is relatively thin ( 5 meters [ 16 feet] or less), very little overall settlement is expected. Additionally, because trenches are used to confine the waste, no lateral displacement is expected. Although no concerted effort has been made to maximize compaction of the waste, evidence from equipment traffic at the SWL site indicates that the site has sufficient bearing capacity. No low-stiffness or sensitive layer exists at the SWL.

Any settlement, subsidence, or displacement effects revealed by quarterly inspections (Table 5-1) will be repaired with the addition of soil to the top layer and regrading. Additional discussion on the potential for cover settlement and subsidence appears in Chapter 4.0, Section 4.3.7.5.

\subsubsection{Vegetative Cover Maintenance}

Since areas of the SWL that ceased activity several years ago have become vegetated with basically the same plant community that surrounds the landfill and surface erosion has been minimal, no efforts are planned to vegetate the bare areas of the SWL.

\subsubsection{Monitoring Equipment}

Groundwater monitoring wells will be maintained during interim closure according to Environmental Investigations Instruction (EII) 6.4 (WHC 1988). This procedure covers correcting problems found during routine inspection or at other times. If maintenance procedures are inadequate to solve the problem, management will decide whether to remediate or replace the well. Landfill gas monitoring wells and vadose zone monitoring equipment have been designed to require no maintenance. Problems identified during routine inspections will be corrected. 


\subsubsection{Benchmark Integrity}

Maintenance of benchmarks has not been a problem to date. The arid environment moderates the growth of vegetation so that the benchmarks are easily observed, but enough ground cover exists so that drifting sand does not cover the benchmarks. If benchmarks are damaged and need to be replaced, replacement will be completed within 90 days of the observation. Benchmarks may be resurveyed if they are out of alignment.

\subsection{ENVIRONMENTAL MONITORING}

The operational environmental monitoring program at the SWL described in Chapter 5.0 of the permit application (DOE-RL 1993) will be continued into the interim closure care period. The overall objectives of the monitoring program, including groundwater, vadose zone, and landfill gas monitoring, are as follows:

- Comply with the monitoring standards of WAC 173-304

- Detect contaminants originating from the SWL and, if detected, assess the nature and extent of contamination

- Insure that landfill gas concentrations do not pose a safety risk

- Protect the environment and the health and safety of employees and the public

- Identify when the landfill becomes stabilized

- Demonstrate the hydrologic performance of the "interim cover."

Monitoring activities will continue for at least a 20-year period following closure, or until the landfill becomes stabilized and monitoring activities can be safely discontinued. Indicators of landfill stabilization include little or no settlement, landfill gas production, or leachate production. If the landfill stabilizes after so many years of monitoring, a cover of more than the natural soils (i.e., "interim cover") may not be required as part of the closure activities.

\subsubsection{Groundwater Monitoring}

The existing groundwater monitoring program (WHC 1993) will continue during the interim closure period. The monitoring network consists of two upgradient wells on the west side of the SWL site and seven downgradient wells along the eastern and southern sides of the SWL (Hodges 1994). The sampling and analysis procedures for groundwater monitoring wells at the SWL are provided in Appendix 5G of the permit application (DOE-RL 1993). Modifications, which will incorporate improved sampling and analytical techniques into the existing plan, likely will be made as new information is gained. 


\subsubsection{Vadose Zone Monitoring}

The existing program for monitoring the vadose zone will continue. The vadose zone monitoring system consists of a lysimeter located within the Phase II area of the SWL. Changes in leachate quality and production will be monitored as a measure of landfill stabilization. The quantity of any leachate produced during the interim closure period will be used to evaluate the hydrologic performance of the operational cover. A vadose zone monitoring plan is provided in Appendix 5H of the permit application (DOE-RL 1993). Modifications, which will incorporate improved sampling and analytical techniques into the existing plan, likely will be made as new information is gained.

\subsubsection{Landfill Gas Monitoring}

Subsurface landfill gas will be monitored through the interim closure period as a continuation of the operational program to demonstrate that the air quality performance standards are met. Changes in landfill gas composition will be monitored to evaluate the waste stabilization process.

\subsection{AMENDMENT TO PLAN}

The interim closure plan may be amended any time during the interim closure care period. The DOE-RL must submit a written request to authorize a change in the approved interim closure plan whenever changes or events occur that affect the interim closure plan.

The approved interim closure plan will be amended by submitting a written request to Ecology for authorization of a change to the approved interim closure plan. The written request will include a copy of the amended interim closure plan for approval.

\subsection{INTERIM CLOSURE CONTACT}

The following office (or its successor) will be the official contact for the SWL during the interim closure care period.

Office of Environmental Assurance, Permits, and Policy

U.S. Department of Energy-Richland Operations Office

P.O. Box 550

Richland, Washington 99352

(509) 376-5441 
DOE/RL-90-38, Rev. 1

\section{5.6 END OF INTERIM CLOSURE CARE}

The DOE-RL will notify Ecology of the date when the SWL site closure activities are to begin. The activities will commence when funding has been made available.

At any time during the interim closure care period, if Ecology finds that interim closure monitoring has established that the SWL is stabilized, Ecology may authorize the owner or operator to discontinue maintenance and monitoring activities. Upon such completion of interim closure care activities, the owner or operator will submit to Ecology a certification of 10 postclosure care. This certification will be signed by the DOE-RL and by a professional 11 engineer stating why closure activities are no longer necessary. The certification will be 12 submitted by registered mail or an equivalent delivery service. Documentation supporting 13 the postclosure certification will be retained and furnished to Ecology on request. 
DOE/RL-90-38, Rev. 1

1

2

3

4

This page intentionally left blank. 
DOE/RL-90-38, Rev. 1

1

2

3

Item

Table 5-1. Inspection Schedule for the Solid Waste Landfill.

\begin{tabular}{llcc} 
& \multicolumn{1}{c}{ Item } & \multicolumn{2}{c}{ Inspection frequency } \\
\cline { 3 - 4 } 3 & & Quarterly & Annually \\
\cline { 3 - 4 } 4 & Security control devices (fences and wells) & $\mathrm{X}$ & \\
5 & Erosion damage to final cover & $\mathrm{X}$ & \\
6 & Cover settlement, subsidence, and & $\mathrm{X}$ & \\
7 & displacement & $\mathrm{X}$ & \\
8 & Condition of vegetative cover & $\mathrm{X}$ & \\
9 & Condition of groundwater and landfill gas & $\mathrm{X}$ & $\mathrm{X}$ \\
10 & monitoring wells & & \\
1 & Lysimeter riser condition & &
\end{tabular}

13 
DOE/RL-90-38, Rev. 1

1

2

3

4

5

This page intentionally left blank. 
DOE/RL-90-38, Rev. 1

1

2

3

\section{CONTENTS}

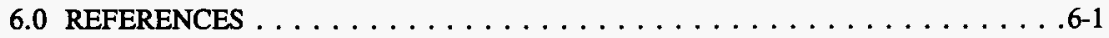

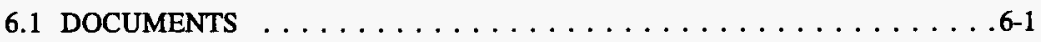

6.2 CODE OF FEDERAL REGULATIONS $\ldots \ldots \ldots \ldots \ldots \ldots$. . . . . . .

6.3 FEDERAL AND STATE ACTS $\ldots \ldots \ldots \ldots \ldots \ldots \ldots \ldots \ldots$

6.4 REVISED CODE OF WASHINGTON AND WASHINGTON ADMINISTRATIVE CODE $\ldots \ldots \ldots \ldots \ldots \ldots \ldots \ldots \ldots \ldots$ 
DOE/RL-90-38, Rev. 1

1

2

3

4

5

This page intentionally left blank. 


\subsection{REFERENCES}

\subsection{DOCUMENTS}

DOE, 1988, Site Characterization Plan, Reference Repository Location, Hanford Site, Washington, Consultation Draft, Vol. 1, DOE/RW-0164, Office of Civilian Radioactive Waste Management, U.S. Department of Energy, Washington, D.C.

DOE-RL, 1990, Closure and Postclosure Plan, Nonradioactive Dangerous Waste Landfill, DOE/RL-90-17, U.S. Department of Energy-Richland Operations Office, Richland, Washington.

DOE-RL, 1993, Hanford Site Solid Waste Landfill Permit Application, DOE/RL-90-38, U.S. Department of Energy-Richland Operations Office, Richland, Washington.

Ecology, EPA, and DOE, 1992, Hanford Federal Facility Agreement and Consent Order, Washington State Department of Ecology, Environmental Protection Agency, and U.S. Department of Energy, Olympia Washington.

Ecology, 1995, (letter from David L. Lundstrom to James E. Rasmussen, DOE-RL, June 7), Washington State Department of Ecology, Kennewick, Washington.

Ecology, 1995, (letter from Fenggang Ma to James E. Rasmussen, DOE-RL, November 20), Washington State Department of Ecology, Kennewick, Washington.

EPA, 1985, Settlement and Cover Subsidence of Hazardous Waste Landfills, EPA/600-2-85-035, U.S. Environmental Protection Agency, Washington, D.C.

Fitzner, R. E., K. A. Gano, W. H. Rickard, and L. E. Rodgers, 1979, Characterization of the Hanford 300 Area Burial Grounds, Task IV - Biological Transport, PNL-2774, Pacific Northwest National Laboratory, Richland, Washington.

Gano, K. A. and J. B. States, 1982, Habitat Requirements and Burrowing Depths of Rodents in Relation to Shallow Waste Burial Sites, PNL-4140, Pacific Northwest Laboratory, Richland, Washington.

Hodges, R. N, 1994, Corrective Action Plan for the Hanford Site Solid Waste Landfill, DOE/RL-94-143, U.S. Department of Energy-Richland Operations Office, Richland, Washington.

Klepper, F. N., K. A. Gano, and L. L. Cadwell, 1995, Rooting Depth and Distributions of Deep Rooted Plants in the 200 Area Control Zone of the Hanford Site, PNL-5247, Pacific Northwest National Laboratory, Richland, Washington. 
Link, S. O., G. W. Gee, M. E. Thiede, and P. A. Beedlow, 1990, Response of ShrubSteppe Ecosystem to Fire: Soil Water and Vegetational Change, Arid Soils Research and rehabilitation, $4: 163-172$.

Link, S. O., L. L. Cadwell, K. L. Petersen, M. R. Sackschewsky, and D. S. Landeen, 1995, The Role of Plants and Animals in Isolation Barriers at Hanford, Washington, PNL-10788, Pacific Northwest National Laboratory, Richland, Washington.

MacKenzie, D. H., L. L. Cadwell, W. E. Kennedy, Jr., L. A. Prohammer, and M. A. Simmons, 1986, Relevance of Biotic Pathways to the Long-Term Regulation of Nuclear Waste Disposal: Phase II Final Report, PNL-4241, Vol. 6, Pacific Northwest National Laboratory, Richland, Washington.

NRC, 1982, Safety Evaluation Report Related to the Operations of WPPSS Nuclear Project No. 2, NUREG-0892, Supplement No. 1, U.S. Nuclear Regulatory Commission, Washington, D.C.

Parametrix, 1987, Solid Waste Landfill Design Manual, Publication No. 87-13 for Washington State Department of Ecology, Parametrix, Inc., Bellevue, Washington.

Schroeder, P. R., C. M. Lloyd, P. A. Zappi, and N. M. Aziz, 1994, The Hydrologic Evaluation of Landfill Performance (HELP) Model, Version 3.04a, EPA/600/R-94/168a, U.S. Amy Corp of Engineers Waterways Experiment Station, Vicksburg, Mississippi.

WHC, 1988 (with revisions to 1996), Environmental Investigations and Site Characterization Manual, WHC-CM-7-7, Westinghouse Hanford Company, Richland, Washington.

WHC, 1991, Geology and Hydrology of the Hanford Site: A Standardized Text for Use in Westinghouse Hanford Company Documents and Reports, WHC-SD-ER-TI-003, Westinghouse Hanford Company, Richland, Washington.

WHC, 1993, Groundwater Monitoring Plan for the Solid Waste Landfill, WHC-SD-EN-AP-043, Westinghouse Hanford Company, Richland, Washington.

Youngs, R. R., K. J. Coppersmith, M. S. Power, and F. H. Swan III, 1985, "Seismic Hazard Assessment of the Hanford region, Eastern Washington State," Proceedings of DOE Natural Phenomena Hazards Mitigation Conference, Conf-8510118, October 711, Las Vegas, Nevada.

\subsection{CODE OF FEDERAL REGULATIONS}

40 CFR 61, "Licensing Requirements for Land Disposal of Radioactive Waste,", Code of Federal Regulation, as amended. 
DOE/RL-90-38, Rev. 1

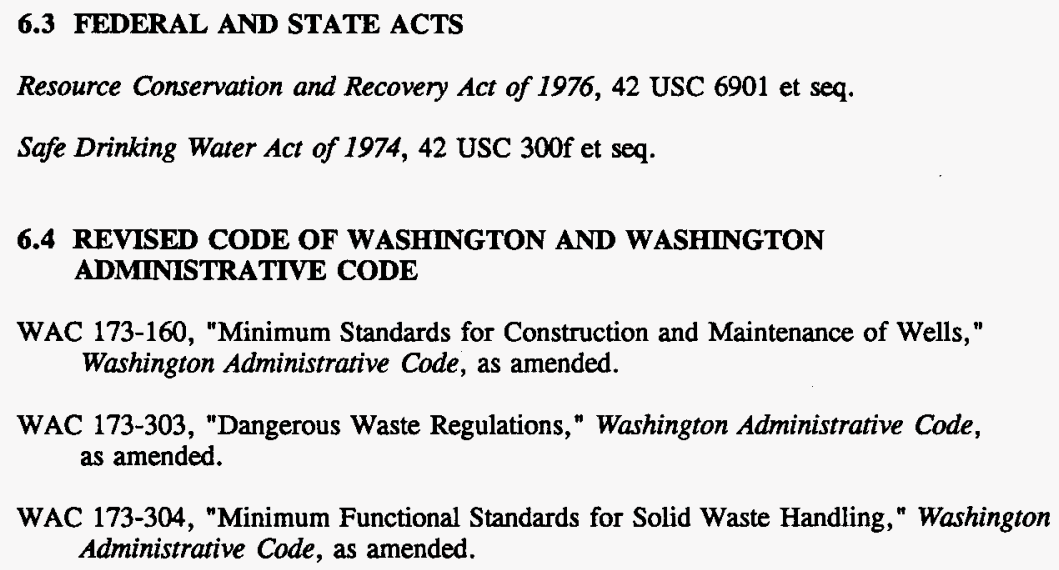

WAC 173-304, "Minimum Functional Standards for Solid Waste Handling," Washington Administrative Code, as amended. 
DOE/RL-90-38, Rev. 1

1

2

3

4

5

This page intentionally left blank. 


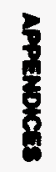


DOE/RL-90-38, Rev. 1

1

2

3

4 APPENDIX A MAPS

5

6 APPENDIX B HELP MODEL RESULTS

\section{APPENDICES}




\section{DOE/RL-90-38, Rev. 1}

1

3

4

5

This page intentionally left blank. 


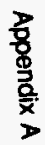


DOE/RL-90-38, Rev. 1

1

APPENDIX A

2

3

MAPS 


\section{DOE/RL-90-38, Rev. 1}

This page intentionally left blank. 


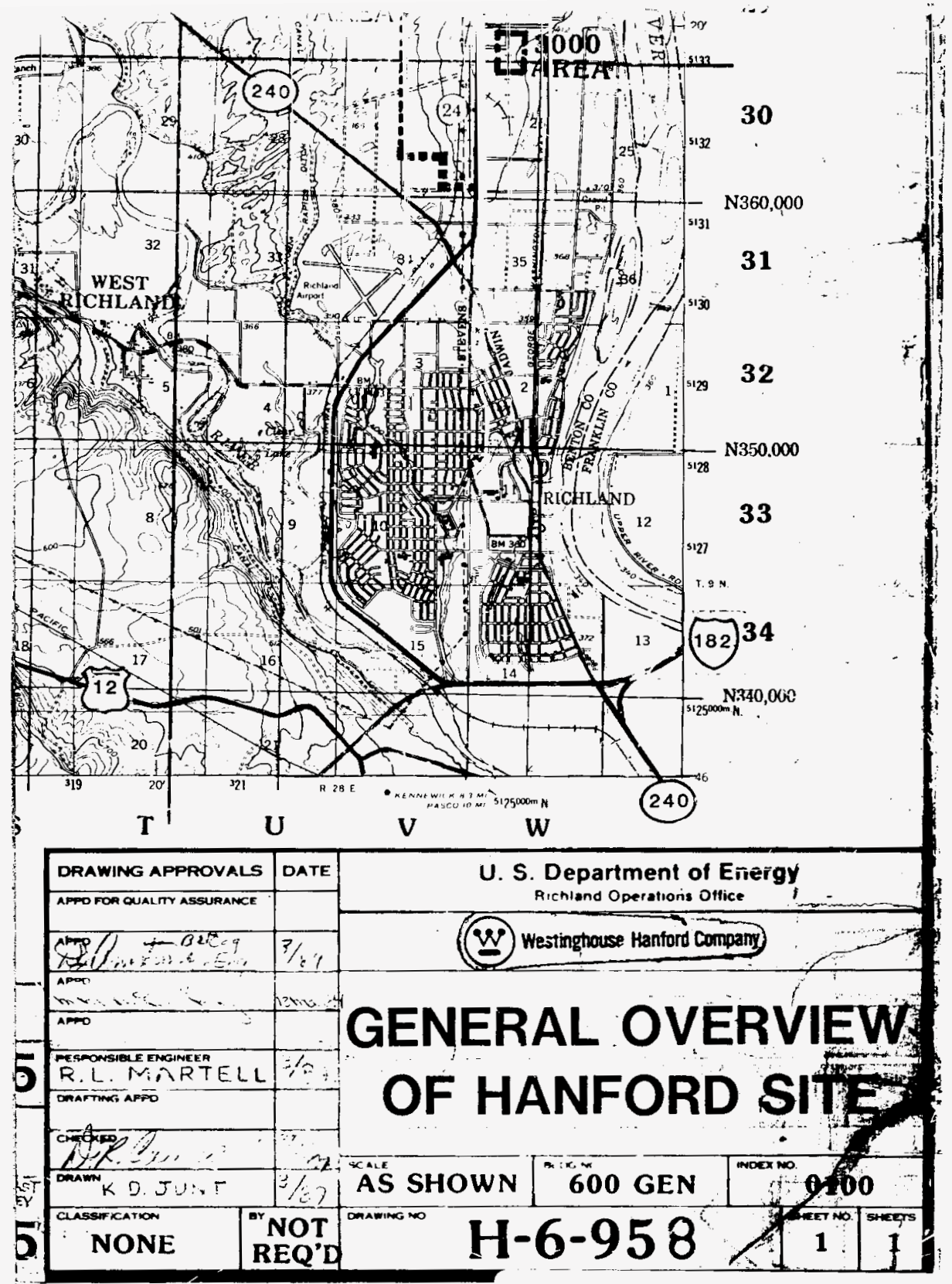




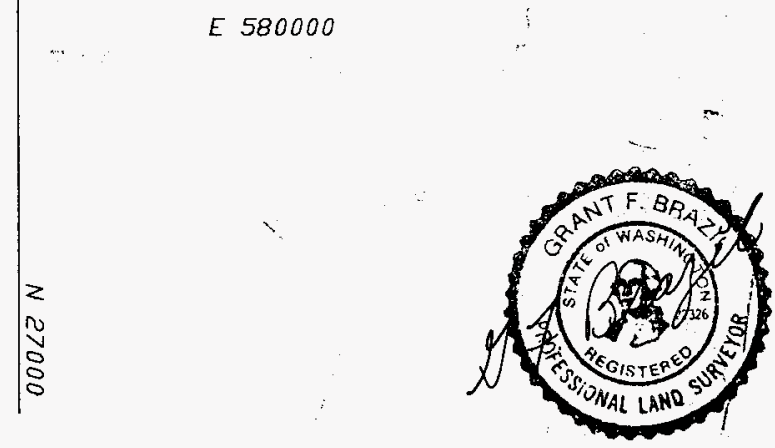

LOCATED AT TCPC, RM. 168

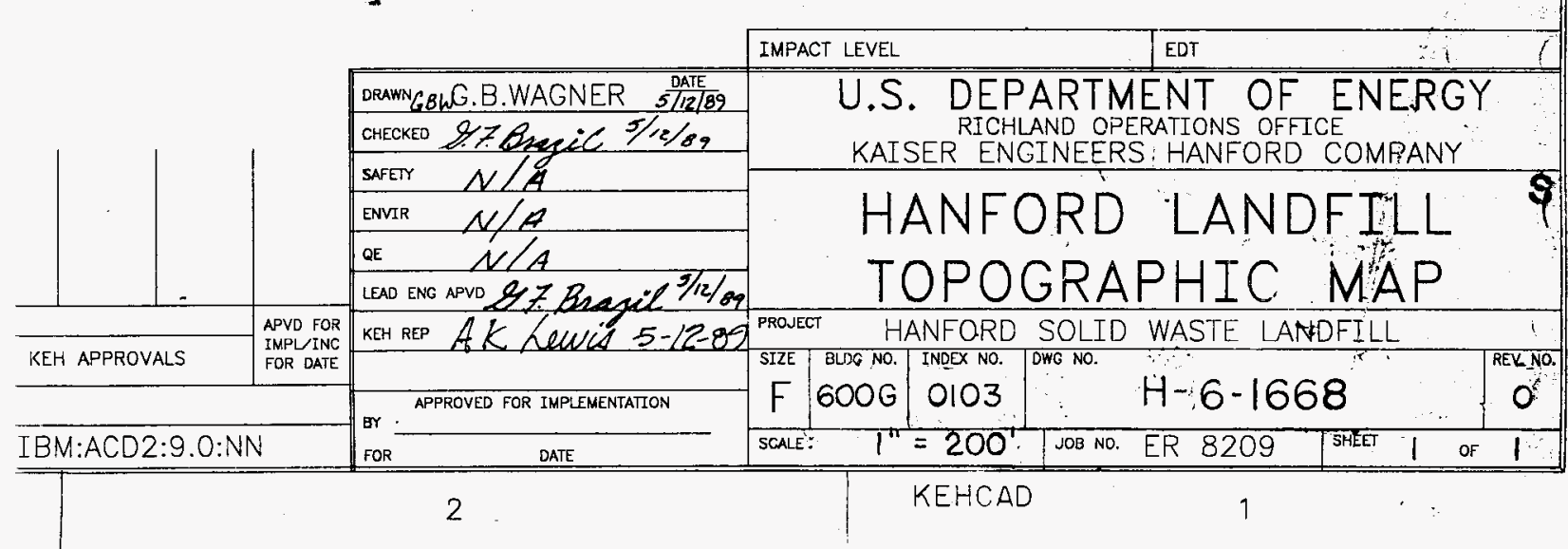




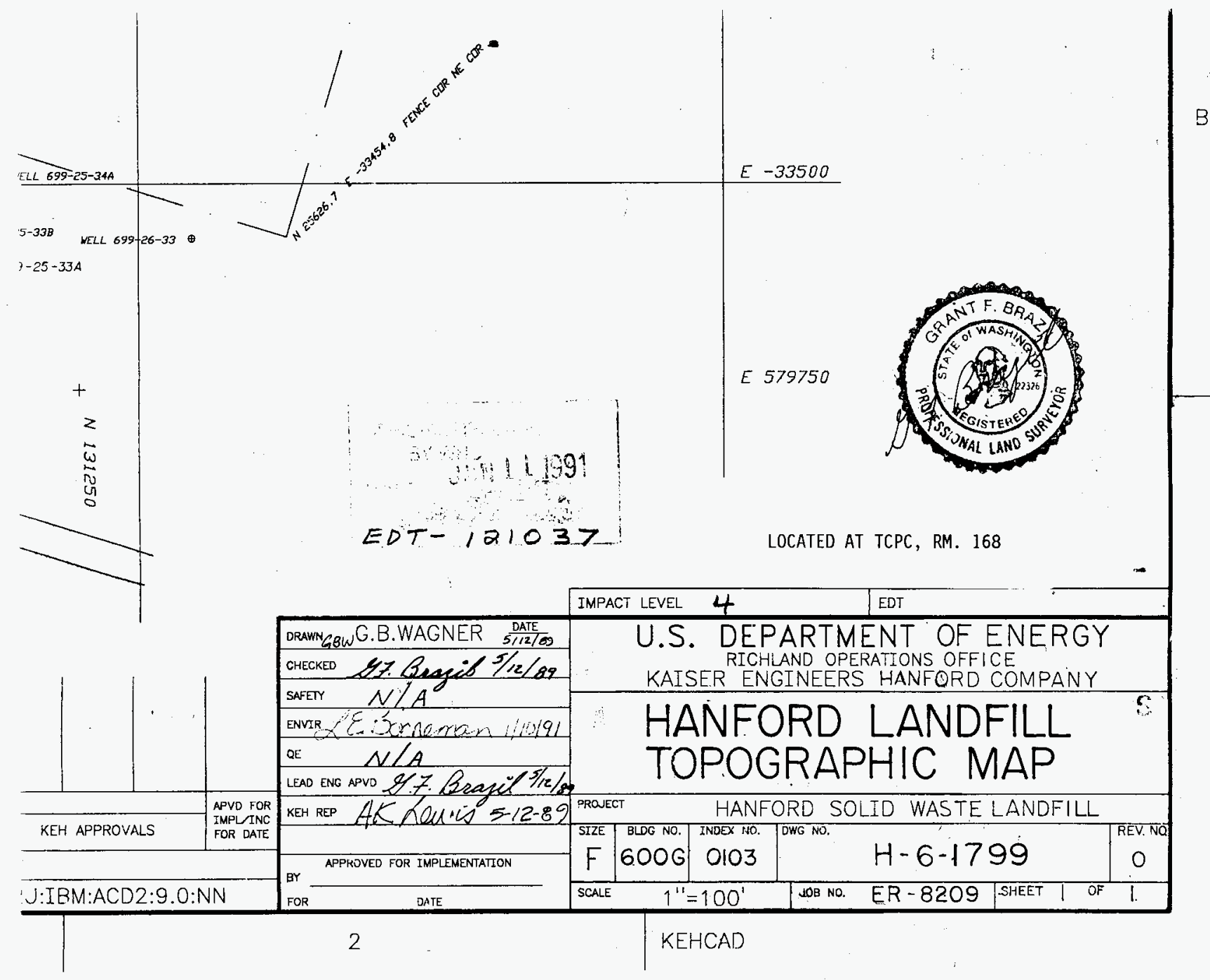


! 
DOE/RL-90-38, Rev. 1

APPENDIX B

HELP MODEL RESULTS 
DOE/RL-90-38, Rev. 1

This page intentionally left blank. 


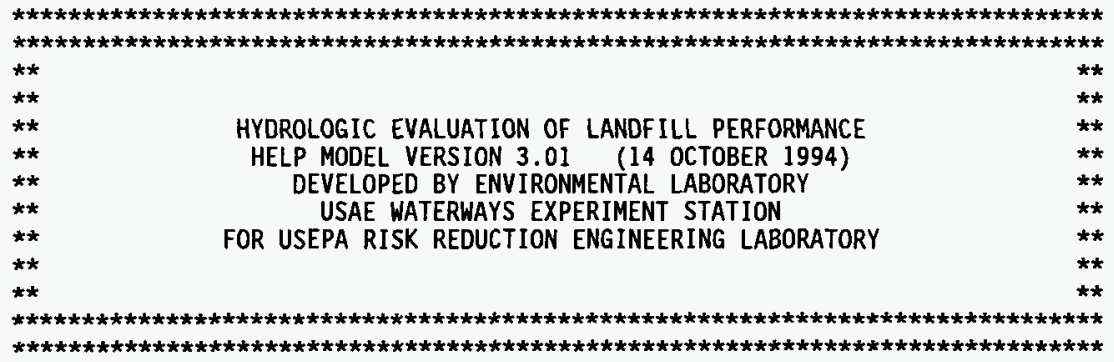

TIME: 10:47 DATE: 11/14/1995

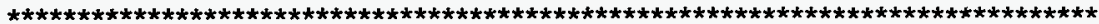

TITLE: Solid Waste Landfill - Operational Cover, C.Sand, No Vegie
} 
NOTE: INITIAL MOISTURE CONTENT OF THE LAYERS AND SNOW WATER WERE SPECIFIED BY THE USER.

$\begin{array}{lcc}\text { LAYER } 1 \\ \text { TYPE 1 - VERTICAL PERCOLATION LAYER } \\ \text { MATERIAL TEXTURE NUMBER } 1 \text { } \\ \text { THICKNESS } & 48.00 \mathrm{INCHES} \\ \text { POROSITY } & = & 0.4170 \mathrm{VOL} / \mathrm{VOL} \\ \text { FIELD CAPACITY } & = & 0.0450 \mathrm{VOL} / \mathrm{VOL} \\ \text { WILTING POINT } & = & 0.0180 \mathrm{VOL} / \mathrm{VOL} \\ \text { INITIAL SOIL WATER CONTENT } & = & 0.0840 \mathrm{VOL} / \mathrm{VOL} \\ \text { EFFECTIVE SAT. HYD. COND. } & = & 0.999999978000 \mathrm{~L}-02 \mathrm{CM} / \mathrm{SEC}\end{array}$

GENERAL DESIGN AND EVAPORATIVE ZONE DATA

NOTE: SCS RUNOFF CURVE NUMBER WAS COMPUTED FROM DEFAULT SOIL DATA BASE USING SOIL TEXTURE \# 1 WITH BARE GROUND CONDITIONS, A SURFACE SLOPE OF $2 . \%$ AND A SLOPE LENGTH OF 500. FEET.

SCS RUNOFF CURVE NUMBER

FRACTION OF AREA ALLOWING RUNOFF= AREA PROJECTED ON HORIZONTAL PLANE = EVAPORATIVE ZONE DEPTH

INITIAL WATER IN EVAPORATIVE ZONE = UPPER LIMIT OF EVAPORATIVE STORAGE = LOWER LIMIT OF EVAPORATIVE STORAGE = INITIAL SNOW WATER INITIAL WATER IN LAYER MATERIALS TOTAL INITIAL WATER TOTAL SUBSURFACE INFLOW
$=72.10$

$=90.0$ PERCENT

66.000 ACRES

16.0 INCHES

1.344 INCHES

6.672 INCHES

0.288 INCHES

0.000 INCHES

4.032 INCHES

4.032 INCHES

0.00 INCHES/YEAR 


\section{EVAPOTRANSPIRATION AND WEATHER DATA}

\section{NOTE: EVAPOTRANSPIRATION DATA WAS OBTAINED FROM Hanford Washington

$\begin{array}{ll}\text { MAXIMUM LEAF AREA INDEX } & =0.00 \\ \text { START OF GROWING SEASON (JULIAN DATE) } & =103 \\ \text { END OF GROWING SEASON (JULIAN DATE) } & =290 \\ \text { AVERAGE ANNUAL WIND SPEED } & =7.50 \mathrm{MPH} \\ \text { AVERAGE 1ST QUARTER RELATIVE HUMIDITY } & =68.60 \% \\ \text { AVERAGE 2ND QUARTER RELATIVE HUMIDITY } & =43.20 \% \\ \text { AVERAGE 3RD QUARTER RELATIVE HUMIDITY } & =37.90 \% \\ \text { AVERAGE 4TH QUARTER RELATIVE HUMIDITY } & =69.40 \%\end{array}$

NOTE: PRECIPITATION DATA FOR HANFORD WASHINGTON WAS ENTERED BY THE USER. NOTE: TEMPERATURE DATA FOR HANFORD W WASHINGTON
WAS ENTERED BY THE USER.

WAS ENTERED BY THE USER.

STATION LATITUDE $=46.30$ DEGREES 
HELP, Version 3 , by EPA Output File: COVER1.OUT

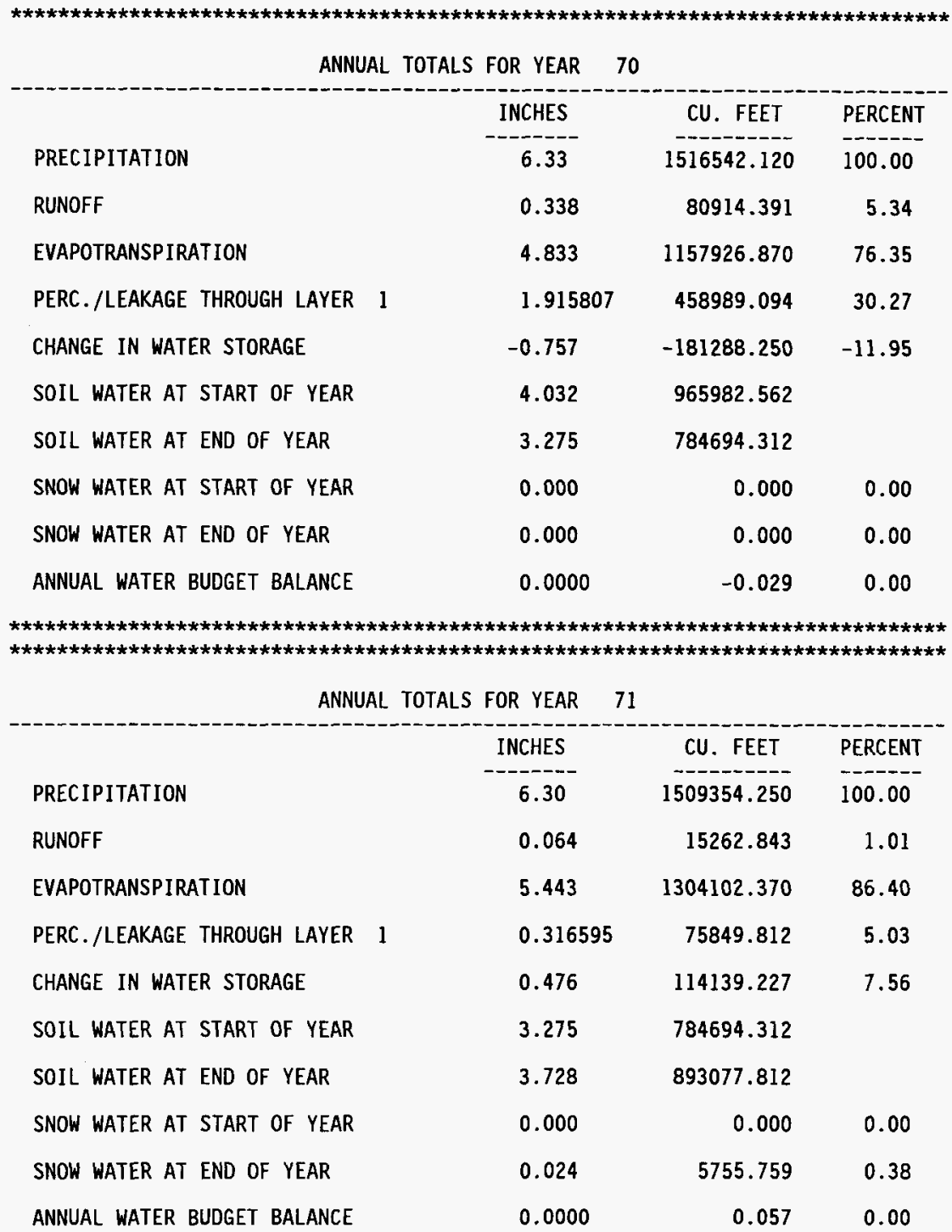

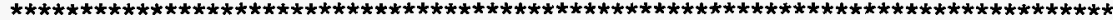




\begin{tabular}{|c|c|c|c|}
\hline \multicolumn{4}{|c|}{ ANNUAL TOTALS FOR YEAR } \\
\hline & INCHES & CU. FEET & PERCENT \\
\hline PRECIPITATION & 6.39 & 1530916.500 & 100.00 \\
\hline RUNOFF & 0.009 & 2218.196 & 0.14 \\
\hline EVAPOTRANSPIRATION & 5.137 & 1230742.620 & 80.39 \\
\hline PERC./LEAKAGE THROUGH LAYER & 1.118456 & 267959.656 & 17.50 \\
\hline CHANGE IN WATER STORAGE & 0.125 & 29995.852 & 1.96 \\
\hline SOIL WATER AT START OF YEAR & 3.728 & 893077.812 & \\
\hline SOIL WATER AT END OF YEAR & 3.877 & 928829.375 & \\
\hline SNOW WATER AT START OF YEAR & 0.024 & 5755.759 & 0.38 \\
\hline SNOW WATER AT END OF YEAR & 0.000 & 0.000 & 0.00 \\
\hline ANNUAL WATER BUDGET BALANCE & 0.0000 & 0.228 & 0.00 \\
\hline \multicolumn{2}{|c|}{ ANNUAL TOTALS FOR YEAR } & & \\
\hline & INCHES & CU. FEET & PERCENT \\
\hline PRECIPITATION & 8.27 & 1981327.000 & 100.00 \\
\hline RUNOFF & 0.085 & 20400.078 & 1.03 \\
\hline EVAPOTRANSPIRATION & 4.725 & 1131904.620 & 57.13 \\
\hline PERC./LEAKAGE THROUGH LAYER & 1.888935 & 452551.031 & 22.84 \\
\hline CHANGE IN WATER STORAGE & 1.571 & 376470.875 & 19.00 \\
\hline SOIL WATER AT START OF YEAR & 3.877 & 928829.375 & \\
\hline SOIL WATER AT END OF YEAR & 4.994 & 1196390.250 & \\
\hline SNOW WATER AT START OF YEAR & 0.000 & 0.000 & 0.00 \\
\hline SNOW WATER AT END OF YEAR & 0.455 & 108909.969 & 5.50 \\
\hline ANNUAL WATER BUDGET BALANCE & 0.0000 & 0.286 & 0.00 \\
\hline
\end{tabular}


HELP, Version 3, by EPA

Output File: COVERI.OUT

\begin{tabular}{|c|c|c|c|}
\hline \multicolumn{4}{|c|}{ ANNUAL TOTALS FOR YEAR } \\
\hline & INCHES & CU. FEET & PERCENT \\
\hline PRECIPITATION & 5.30 & 1269774.250 & 100.00 \\
\hline RUNOFF & 0.061 & 14538.642 & 1.14 \\
\hline EVAPOTRANSPIRATION & 4.975 & 1191824.870 & 93.86 \\
\hline PERC./LEAKAGE THROUGH LAYER 1 & 1.688262 & 404473.875 & 31.85 \\
\hline CHANGE IN WATER STORAGE & -1.424 & -341063.094 & -26.86 \\
\hline SOIL WATER AT START OF YEAR & 4.994 & 1196390.250 & \\
\hline SOIL WATER AT END OF YEAR & 4.025 & 964237.187 & \\
\hline SNOW WATER AT START OF YEAR & 0.455 & 108909.969 & 8.58 \\
\hline SNOW WATER AT END OF YEAR & 0.000 & 0.000 & 0.00 \\
\hline ANNUAL WATER BUDGET BALANCE & 0.0000 & -0.057 & 0.00 \\
\hline \multicolumn{3}{|c|}{ 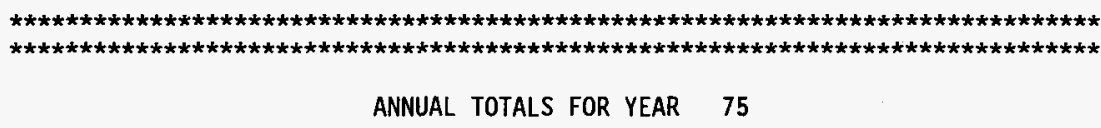 } & \\
\hline & INCHES & CU. FEET & PERCENT \\
\hline PRECIPITATION & 7.73 & 1851953.500 & 100.00 \\
\hline RUNOFF & 0.029 & 6914.992 & 0.37 \\
\hline EVAPOTRANSPIRATION & 6.982 & 1672695.000 & 90.32 \\
\hline PERC./LEAKAGE THROUGH LAYER I & 1.217512 & 291691.562 & 15.75 \\
\hline CHANGE IN WATER STORAGE & -0.498 & -119347.258 & -6.44 \\
\hline SOIL WATER AT START OF YEAR & 4.025 & 964237.187 & \\
\hline SOIL WATER AT END OF YEAR & 3.527 & 844889.937 & \\
\hline SNOW WATER AT START OF YEAR & 0.000 & 0.000 & 0.00 \\
\hline SNOW WATER AT END OF YEAR & 0.000 & 0.000 & 0.00 \\
\hline ANNUAL WATER BUDGET BALANCE & 0.0000 & -0.743 & 0.00 \\
\hline
\end{tabular}




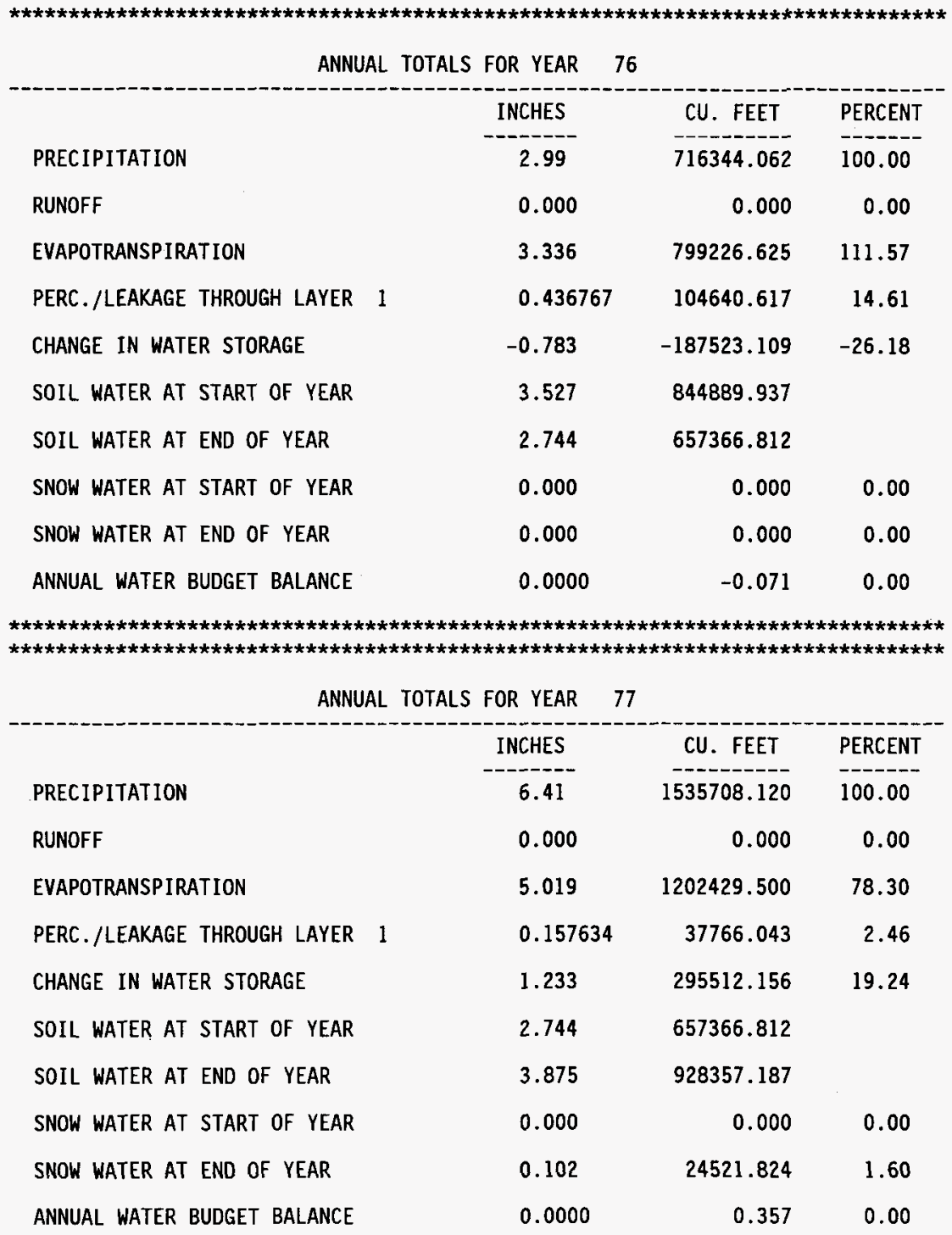




\begin{tabular}{|c|c|c|c|}
\hline \multicolumn{4}{|c|}{ ANNUAL TOTALS FOR YEAR } \\
\hline & INCHES & CU. FEET & PERCENT \\
\hline PRECIPITATION & 6.37 & 1526125.000 & 100.00 \\
\hline RUNOFF & 0.050 & 12076.380 & 0.79 \\
\hline EVAPOTRANSPIRATION & 5.905 & 1414711.500 & 92.70 \\
\hline PERC./LEAKAGE THROUGH LAYER 1 & 1.138864 & 272849.031 & 17.88 \\
\hline CHANGE IN WATER STORAGE & -0.724 & -173511.672 & -11.37 \\
\hline SOIL WATER AT START OF YEAR & 3.875 & 928357.187 & \\
\hline SOIL WATER AT END OF YEAR & 3.253 & 779367.312 & \\
\hline SNOW WATER AT START OF YEAR & 0.102 & 24521.824 & 1.61 \\
\hline SNOW WATER AT END OF YEAR & 0.000 & 0.000 & 0.00 \\
\hline ANNUAL WATER BUDGET BALANCE & 0.0000 & -0.200 & 0.00 \\
\hline \multicolumn{4}{|c|}{ 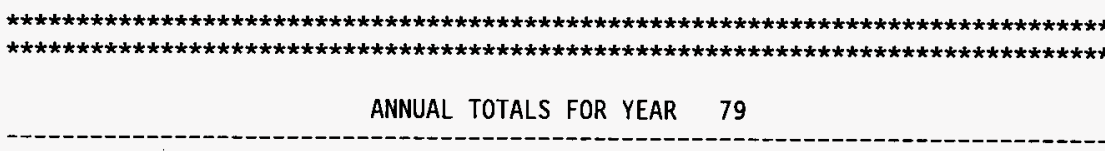 } \\
\hline \multicolumn{2}{|c|}{ INCHES } & CU. FEET & PERCENT \\
\hline PRECIPITATION & 5.56 & 1332064.870 & 100.00 \\
\hline RUNOFF & 0.000 & 0.000 & 0.00 \\
\hline EVAPOTRANSPIRATION & 5.035 & 1206359.870 & 90.56 \\
\hline PERC./LEAKAGE THROUGH LAYER 1 & 0.251175 & 60176.480 & 4.52 \\
\hline CHANGE IN WATER STORAGE & 0.274 & 65528.094 & 4.92 \\
\hline SOIL WATER AT START OF YEAR & 3.253 & 779367.312 & \\
\hline SOIL WATER AT END OF YEAR & 3.353 & 803194.937 & \\
\hline SNOW WATER AT START OF YEAR & 0.000 & 0.000 & 0.00 \\
\hline SNOW WATER AT END OF YEAR & 0.174 & 41700.523 & 3.13 \\
\hline ANNUAL WATER BUDGET BALANCE & 0.0000 & 0.464 & 0.00 \\
\hline
\end{tabular}


HELP, Version 3, by EPA

Output File: COVER1.OUT

\begin{tabular}{|c|c|c|c|}
\hline ANNUAL TOTALS & FOR YEAR 8 & 80 & \\
\hline & INCHES & CU. FEET & PERCENT \\
\hline PRECIPITATION & 9.68 & 2319135.250 & 100.00 \\
\hline RUNOFF & 0.003 & 619.144 & 0.03 \\
\hline EVAPOTRANSPIRATION & 8.590 & 2058048.500 & 88.74 \\
\hline PERC./LEAKAGE THROUGH LAYER 1 & 0.780434 & 186976.437 & 8.06 \\
\hline CHANGE IN WATER STORAGE & 0.307 & 73491.695 & 3.17 \\
\hline SOIL WATER AT START OF YEAR & 3.353 & 803194.937 & \\
\hline SOIL WATER AT END OF YEAR & 3.833 & 918387.125 & \\
\hline SNOW WATER AT START OF YEAR & 0.174 & 41700.520 & 1.80 \\
\hline SNOW WATER AT END OF YEAR & 0.000 & 0.000 & 0.00 \\
\hline ANNUAL WATER BUDGET BALANCE & 0.0000 & -0.557 & 0.00 \\
\hline ANNUAL TOTALS & FOR YEAR & 81 & \\
\hline & INCHES & CU. FEET & PERCENT \\
\hline PRECIPITATION & 7.04 & 1686643.120 & 100.00 \\
\hline RUNOFF & 0.000 & 0.000 & 0.00 \\
\hline EVAPOTRANSPIRATION & 6.228 & 1492191.250 & 88.47 \\
\hline PERC./LEAKAGE THROUGH LAYER I & 0.505702 & 121156.086 & 7.18 \\
\hline CHANGE IN WATER STORAGE & 0.306 & 73296.344 & 4.35 \\
\hline SOIL WATER AT START OF YEAR & 3.833 & 918387.125 & \\
\hline SOIL WATER AT END OF YEAR & 4.128 & 988907.562 & \\
\hline SNOW WATER AT START OF YEAR & 0.000 & 0.000 & 0.00 \\
\hline SNOW WATER AT END OF YEAR & 0.012 & 2775.876 & 0.16 \\
\hline ANNUAL WATER BUDGET BALANCE & 0.0000 & -0.571 & 0.00 \\
\hline
\end{tabular}


HELP, Version 3, by EPA

Output File: COVER1.OUT

\begin{tabular}{|c|c|c|c|}
\hline \multicolumn{4}{|c|}{ ANNUAL TOTALS FOR YEAR 82} \\
\hline & INCHES & CU. FEET & PERCENT \\
\hline PRECIPITATION & 7.98 & 1911848.370 & 100.00 \\
\hline RUNOFF & 0.000 & 0.000 & 0.00 \\
\hline EVAPOTRANSPIRATION & 7.055 & 1690126.500 & 88.40 \\
\hline PERC./LEAKAGE THROUGH LAYER I & 0.421641 & 101016.781 & 5.28 \\
\hline CHANGE IN WATER STORAGE & 0.504 & 120705.352 & 6.31 \\
\hline SOIL WATER AT START OF YEAR & 4.128 & 988907.562 & \\
\hline SOIL WATER AT END OF YEAR & 4.643 & 1112388.870 & \\
\hline SNOW WATER AT START OF YEAR & 0.012 & 2775.876 & 0.15 \\
\hline SNOW WATER AT END OF YEAR & 0.000 & 0.000 & 0.00 \\
\hline ANNUAL WATER BUDGET BALANCE & 0.0000 & -0.236 & 0.00 \\
\hline \multicolumn{4}{|c|}{ 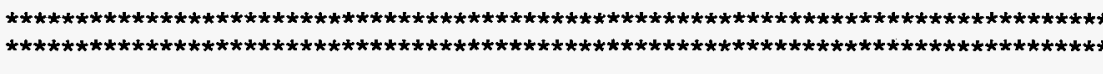 } \\
\hline \multicolumn{2}{|c|}{ ANNUAL TOTALS FOR YEAR } & 83 & \\
\hline & INCHES & CU. FEET & PERCENT \\
\hline PRECIPITATION & 11.07 & 2652151.250 & 100.00 \\
\hline RUNOFF & 0.050 & 11986.617 & 0.45 \\
\hline EVAPOTRANSPIRATION & 8.337 & 1997492.250 & 75.32 \\
\hline PERC./LEAKAGE THROUGH LAYER I & 1.757949 & 421169.406 & 15.88 \\
\hline CHANGE IN WATER STORAGE & 0.925 & 221503.141 & 8.35 \\
\hline SOIL WATER AT START OF YEAR & 4.643 & 1112388.870 & \\
\hline SOIL WATER AT END OF YEAR & 4.878 & 1168761.250 & \\
\hline SNOW WATER AT START OF YEAR & 0.000 & 0.000 & 0.00 \\
\hline SNOW WATER AT END OF YEAR & 0.689 & 165130.750 & 6.23 \\
\hline ANNUAL WATER BUDGET BALANCE & 0.0000 & -0.171 & 0.00 \\
\hline
\end{tabular}




\begin{tabular}{|c|c|c|c|}
\hline ANNUAL & FOR YEAR & & \\
\hline & INCHES & CU. FEET & PERCENT \\
\hline PRECIPITATION & 7.27 & 1741746.750 & 100.00 \\
\hline RUNOFF & 0.123 & 29476.314 & 1.69 \\
\hline EVAPOTRANSPIRATION & 7.039 & 1686445.250 & 96.82 \\
\hline PERC./LEAKAGE THROUGH LAYER 1 & 1.450336 & 347471.406 & 19.95 \\
\hline CHANGE IN WATER STORAGE & -1.343 & -321646.000 & -18.47 \\
\hline SOIL WATER AT START OF YEAR & 4.878 & 1168761.250 & \\
\hline SOIL WATER AT END OF YEAR & 4.154 & 995272.062 & \\
\hline SNOW WATER AT START OF YEAR & 0.689 & 165130.750 & 9.48 \\
\hline SNOW WATER AT END OF YEAR & 0.071 & 16973.926 & 0.97 \\
\hline ANNUAL WATER BUDGET BALANCE & 0.0000 & -0.228 & 0.00 \\
\hline
\end{tabular}

ANNUAL TOTALS FOR YEAR 85

\begin{tabular}{|c|c|c|c|}
\hline & INCHES & CU. FEET & PERCENT \\
\hline PRECIPITATION & 5.10 & 1221858.000 & 100.00 \\
\hline RUNOFF & 0.167 & 40002.535 & 3.27 \\
\hline EVAPOTRANSPIRATION & 4.018 & 962695.625 & 78.79 \\
\hline PERC./LEAKAGE THROUGH LAYER 1 & 0.695653 & 166664.484 & 13.64 \\
\hline CHANGE IN WATER STORAGE & 0.219 & 52495.289 & 4.30 \\
\hline SOIL WATER AT START OF YEAR & 4.154 & 995272.062 & \\
\hline SOIL WATER AT END OF YEAR & 4.059 & 972549.375 & \\
\hline SNOW WATER AT START OF YEAR & 0.071 & 16973.926 & 1.39 \\
\hline SNOW WATER AT END OF YEAR & 0.385 & 92191.906 & 7.55 \\
\hline ANNUAL WATER BUDGET BALANCE & 0.0000 & 0.029 & 0.00 \\
\hline
\end{tabular}




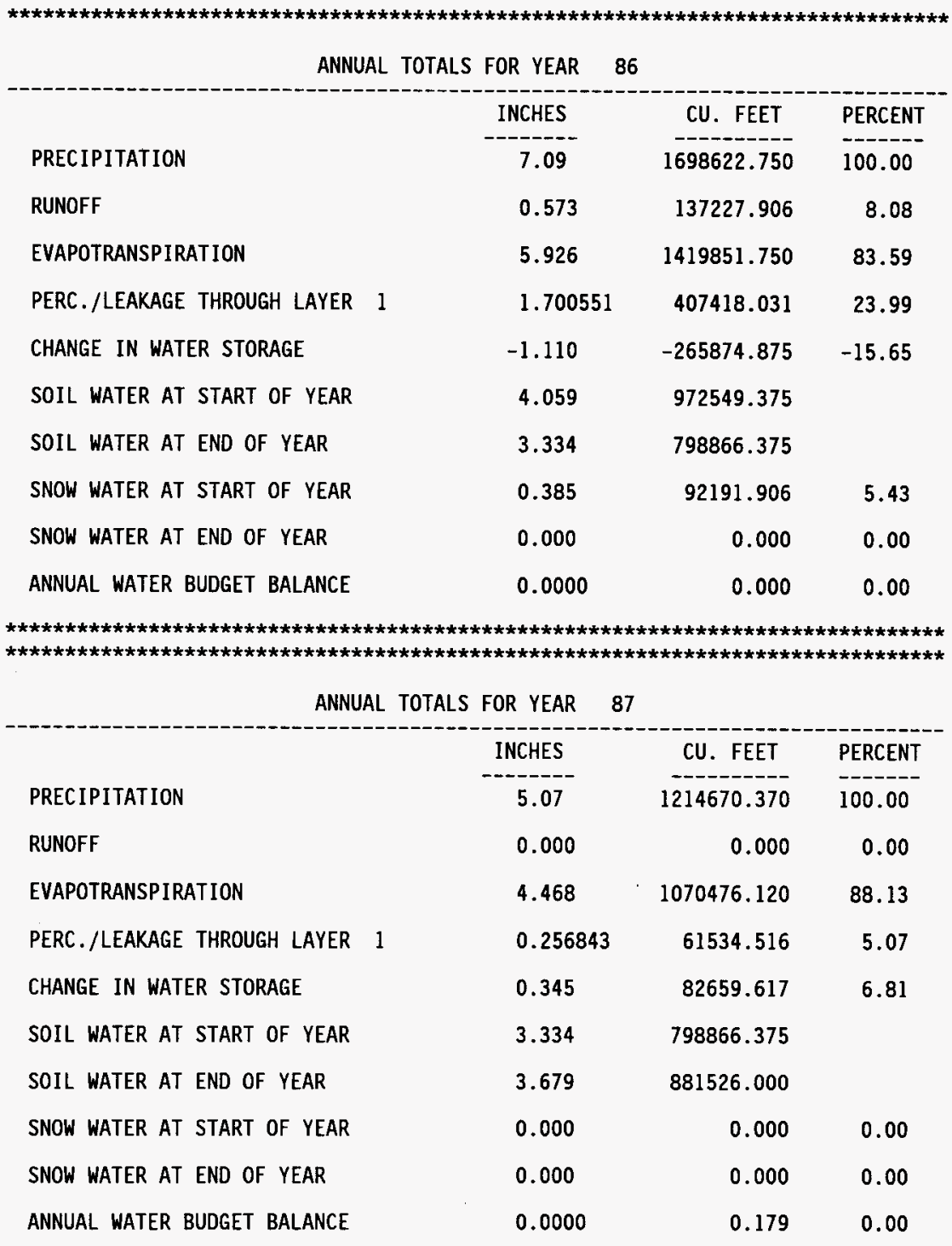

$$
\star *
$$




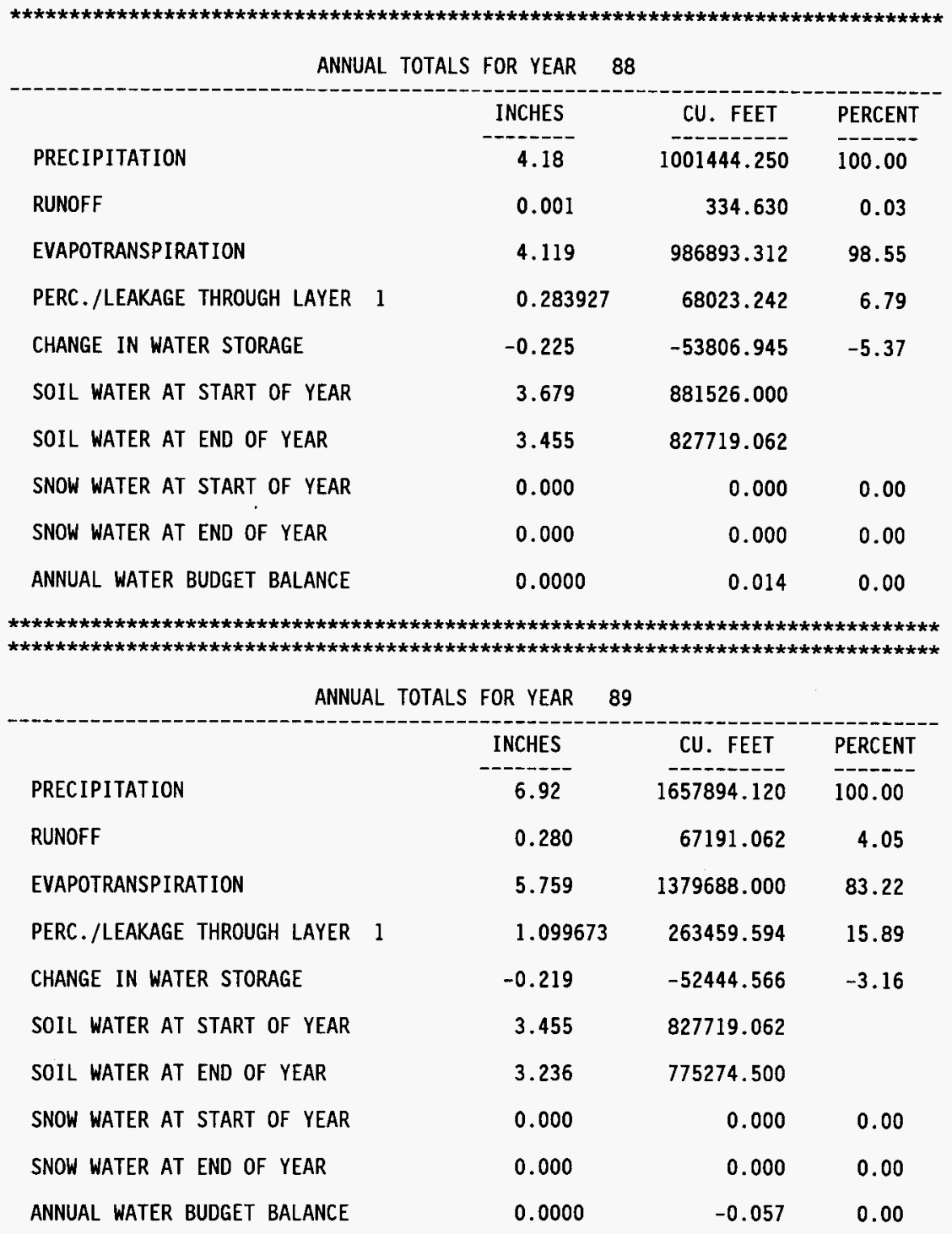




\begin{tabular}{|c|c|c|c|}
\hline \multicolumn{4}{|c|}{ ANNUAL TOTALS FOR YEAR } \\
\hline & INCHES & CU. FEET & PERCENT \\
\hline PRECIPITATION & 5.07 & 1214670.620 & 100.00 \\
\hline RUNOFF & 0.000 & 0.000 & 0.00 \\
\hline EVAPOTRANSPIRATION & 4.846 & 1160902.870 & 95.57 \\
\hline PERC./LEAKAGE THROUGH LAVER 1 & 0.229552 & 54996.070 & 4.53 \\
\hline CHANGE IN WATER STORAGE & -0.005 & -1228.319 & -0.10 \\
\hline SOIL WATER AT START OF YEAR & 3.236 & 775274.500 & \\
\hline SOIL WATER AT END OF YEAR & 3.075 & 736714.437 & \\
\hline SNOW WATER AT START OF YEAR & 0.000 & 0.000 & 0.00 \\
\hline SNOW WATER AT END OF YEAR & 0.156 & 37331.727 & 3.07 \\
\hline ANNUAL WATER BUDGET BALANCE & 0.0000 & 0.064 & 0.00 \\
\hline ANNUAL & TOTALS FOR YEAR & & \\
\hline & INCHES & CU. FEET & PERCENT \\
\hline PRECIPITATION & 6.75 & 1617165.120 & 100.00 \\
\hline RUNOFF & 0.004 & 876.436 & 0.05 \\
\hline EVAPOTRANSPIRATION & 6.575 & 1575231.250 & 97.41 \\
\hline PERC./LEAKAGE THROUGH LAYER 1 & 0.326005 & 78104.398 & 4.83 \\
\hline CHANGE IN WATER STORAGE & -0.155 & -37045.781 & -2.29 \\
\hline SOIL WATER AT START OF YEAR & 3.075 & 736714.437 & \\
\hline SOIL WATER AT END OF YEAR & 3.076 & 737000.375 & \\
\hline SNOW WATER AT START OF YEAR & 0.156 & 37331.727 & 2.31 \\
\hline SNOW WATER AT END OF YEAR & 0.000 & 0.000 & 0.00 \\
\hline ANNUAL WATER BUDGET BALANCE & 0.0000 & -1.192 & 0.00 \\
\hline
\end{tabular}




\begin{tabular}{|c|c|c|c|}
\hline ANNUAL & TOTALS FOR YEAR & & \\
\hline & INCHES & CU. FEET & PERCENT \\
\hline PRECIPITATION & 7.90 & 1892682.250 & 100.00 \\
\hline RUNOFF & 0.000 & 0.000 & 0.00 \\
\hline EVAPOTRANSPIRATION & 6.276 & 1503607.000 & 79.44 \\
\hline PERC./LEAKAGE THROUGH LAYER 1 & 0.302206 & 72402.531 & 3.83 \\
\hline CHANGE IN WATER STORAGE & 1.322 & 316673.281 & 16.73 \\
\hline SOIL WATER AT START OF YEAR & 3.076 & 737000.375 & \\
\hline SOIL WATER AT END OF YEAR & 3.786 & 907120.625 & \\
\hline SNOW WATER AT START OF YEAR & 0.000 & 0.000 & 0.00 \\
\hline SNOW WATER AT END OF YEAR & 0.612 & 146553.000 & 7.74 \\
\hline ANNUAL WATER BUDGET BALANCE & 0.0000 & -0.493 & 0.00 \\
\hline
\end{tabular}

\begin{tabular}{|c|c|c|c|}
\hline ANNUAL. TOTALS & FOR YEAR & & \\
\hline & INCHES & CU. FEET & PERCENT \\
\hline PRECIPITATION & 7.83 & 1875911.620 & 100.00 \\
\hline RUNOFF & 0.524 & 125492.648 & 6.69 \\
\hline EVAPOTRANSPIRATION & 6.931 & 1660478.500 & 88.52 \\
\hline PERC. /LEAKAGE THROUGH LAYER 1 & 1.209354 & 289737.000 & 15.45 \\
\hline CHANGE IN WATER STORAGE & -0.834 & -199795.547 & -10.65 \\
\hline SOIL WATER AT START OF YEAR & 3.786 & 907120.625 & \\
\hline SOIL WATER AT END OF YEAR & 3.533 & 846402.187 & \\
\hline SNOW WATER AT START OF YEAR & 0.612 & 146553.000 & 7.81 \\
\hline SNOW WATER AT END OF YEAR & 0.031 & 7475.901 & 0.40 \\
\hline ANNUAL WATER BUDGET BALANCE & 0.0000 & -1.028 & 0.00 \\
\hline
\end{tabular}




\begin{tabular}{|c|c|c|c|}
\hline ANNUAL & TOTALS FOR YEAR & 94 & \\
\hline & INCHES & CU. FEET & PERCENT \\
\hline PRECIPITATION & 6.12 & 1466230.120 & 100.00 \\
\hline RUNOFF & 0.000 & 0.000 & 0.00 \\
\hline EVAPOTRANSPIRATION & 4.947 & 1185232.620 & 80.84 \\
\hline PERC./LEAKAGE THROUGH LAYER 1 & 0.696318 & 166823.875 & 11.38 \\
\hline CHANGE IN WATER STORAGE & 0.477 & 114172.680 & 7.79 \\
\hline SOIL WATER AT START OF YEAR & 3.533 & 846402.187 & \\
\hline SOIL WATER AT END OF YEAR & 4.041 & 968050.812 & \\
\hline SNOW WATER AT START OF YEAR & 0.031 & 7475.901 & 0.51 \\
\hline SNOW WATER AT END OF YEAR & 0.000 & 0.000 & 0.00 \\
\hline ANNUAL WATER BUDGET BALANCE & 0.0000 & 0.942 & 0.00 \\
\hline
\end{tabular}




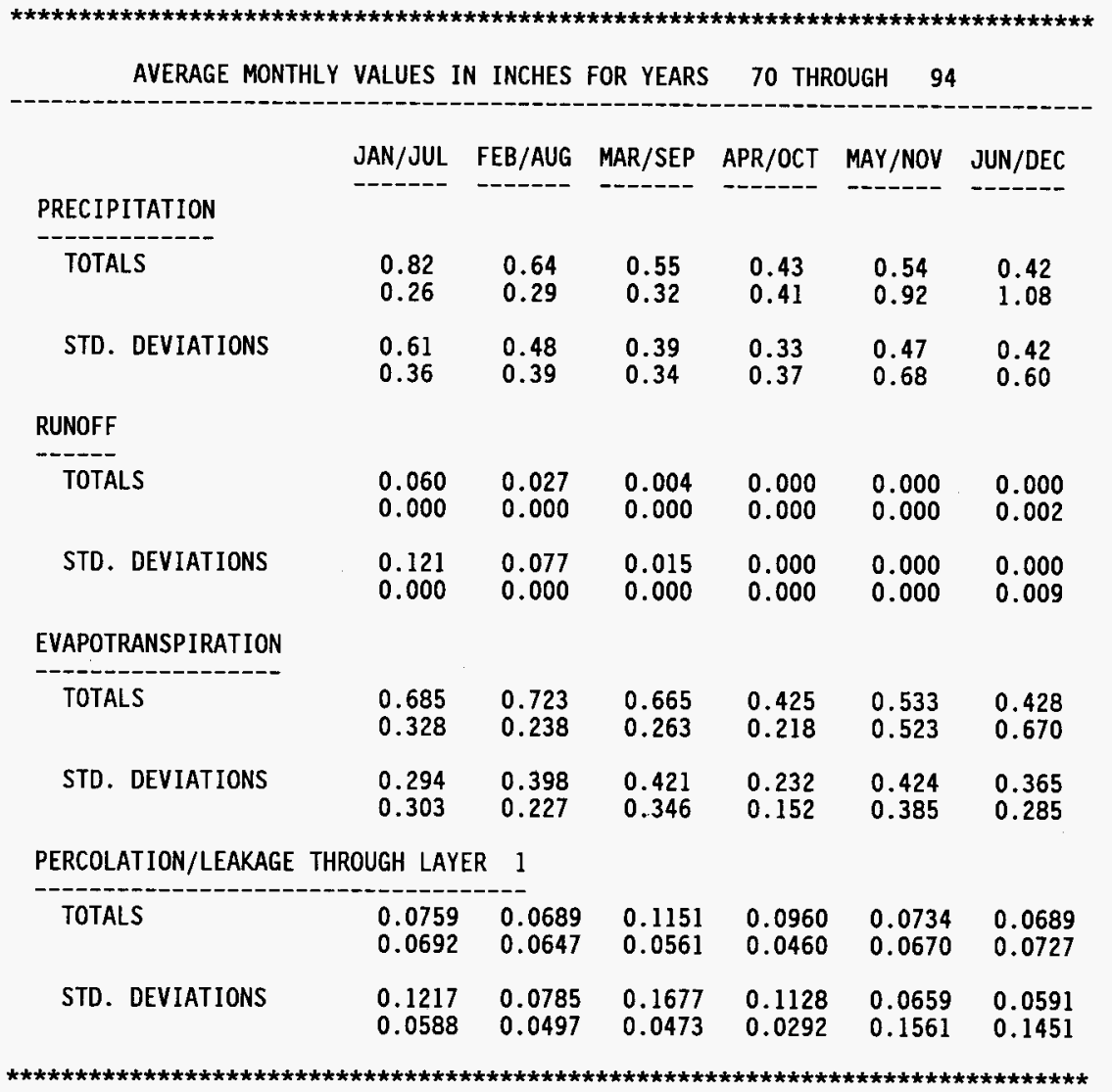


HELP, Version 3 , by EPA

Output File: COVER1.OUT

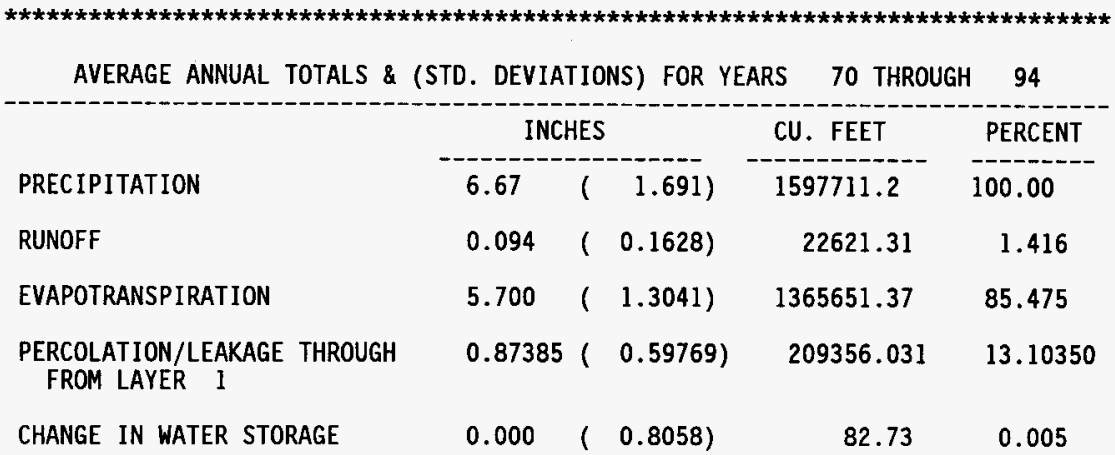

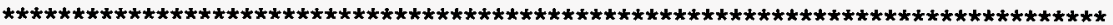

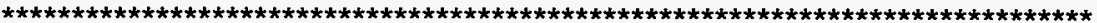

PEAK DAILY VALUES FOR YEARS 70 THROUGH 94

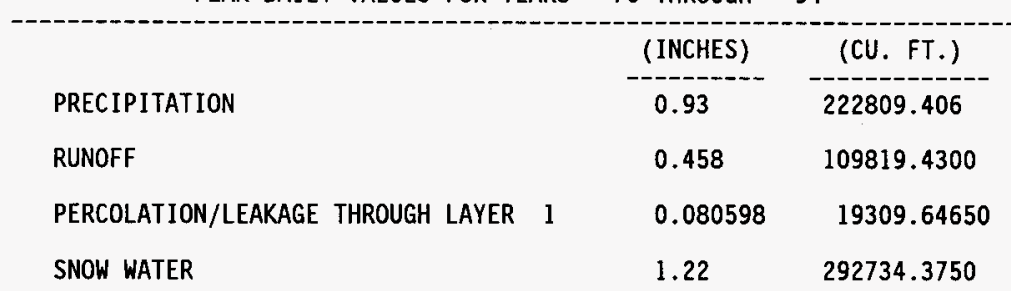

MAXIMUM VEG. SOIL WATER (VOL/VOL) 0.1861

MINIMUM VEG. SOIL WATER (VOL/VOL) 0.0122

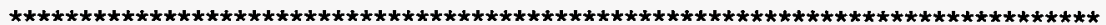

FINAL WATER STORAGE AT END OF YEAR 94

\begin{tabular}{ccc} 
LAYER & (INCHES) & (VOL/VOL) \\
\hdashline 1 & 4.0411 & 0.0842
\end{tabular}

SNOW WATER $\quad 0.000$

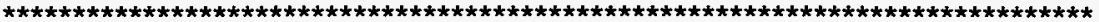

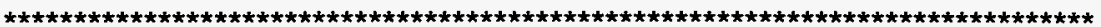




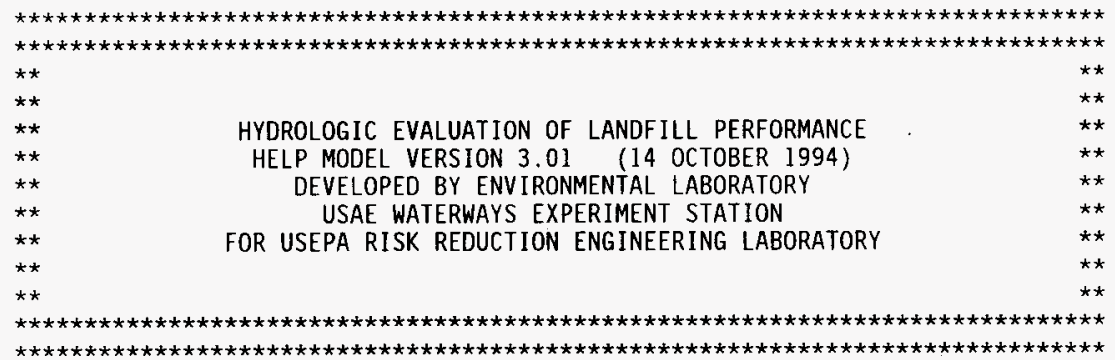
PRECIPITATION DATA FILE:
$C: \backslash$ HELP3 \HNFDPRCP.D4
TEMPERATURE DATA FILE:
C: \HELP3\HNFDTEMP.D7
SOLAR RADIATION DATA FILE: C: \HELP3\HNFDSUN.D13
EVAPOTRANSPIRATION DATA: C: \HELP3\HNFDBARE.D11
SOIL AND DESIGN DATA FILE: C: \HELP3\OPSCVR-M.D10
OUTPUT DATA FILE:
$C: \backslash$ HELP3 COVER2.OUT

TIME: $10: 59$ DATE: $11 / 14 / 1995$

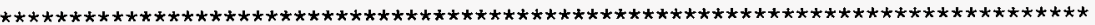

TITLE: Solid Waste Landfill - Operational Cover, M.Sand, No Vegie 
NOTE: INITIAL MOISTURE CONTENT OF THE LAYERS AND SNOW WATER WERE SPECIFIED BY THE USER.

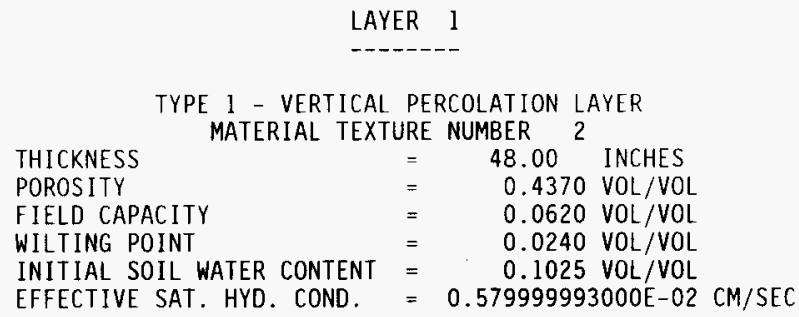

GENERAL DESIGN AND EVAPORATIVE ZONE DATA

NOTE: SCS RUNOFF CURVE NUMBER WAS COMPUTED FROM DEFAULT SOIL DATA BASE USING SOIL IEXTURE \# 2 WITH BARE GROUND CONDITIONS, A SURFACE SLOPE OF $2 . \%$ AND A SLOPE LENGTH OF 500. FEET.

$\begin{array}{llll}\text { SCS RUNOFF CURVE NUMBER } & = & 79.30 & \\ \text { FRACTION OF AREA ALLOWING RUNOFF } & =90.0 & \text { PERCENT } \\ \text { AREA PROJECTED ON HORIZONTAL PLANE } & = & 66.000 & \text { ACRES } \\ \text { EVAPORATIVE ZONE DEPTH } & = & 16.0 & \text { INCHES } \\ \text { INITIAL WATER IN EVAPORATIVE ZONE } & = & 1.640 & \text { INCHES } \\ \text { UPPER LIMIT OF EVAPORATIVE STORAGE } & = & 6.992 & \text { INCHES } \\ \text { LOWER LIMIT OF EVAPORATIVE STORAGE } & = & 0.384 & \text { INCHES } \\ \text { INITIAL SNOW WATER } & = & 0.000 & \text { INCHES } \\ \text { INITIAL WATER IN LAYER MATERIALS } & = & 4.920 & \text { INCHES } \\ \text { TOTAL INIIIAL WATER } & = & 4.920 & \text { INCHES } \\ \text { TOTAL SUBSURFACE INFLOW } & = & 0.00 & \text { INCHES/YEAR }\end{array}$


NOTE: EVAPOTRANSPIRATION DATA WAS OBTAINED FROM Hanford Washington

MAXIMUM LEAF AREA INDEX $=0.00$

START OF GROWING SEASON (JULIAN DATE) $=103$

END OF GROWING SEASON (JULIAN DATE) $=290$

AVERAGE ANNUAL WIND SPEED $=7.50 \mathrm{MPH}$

AVERAGE 1ST QUARTER RELATIVE HUMIDITY $=68.60 \%$

AVERAGE 2ND QUARTER RELATIVE HUMIDITY $=43.20 \%$

AVERAGE 3RD QUARTER RELATIVE HUMIDITY $=37.90 \%$

AVERAGE 4TH QUARTER RELATIVE HUMIDITY $=69.40 \%$

NOTE: PRECIPITATION DATA FOR HANFORD
WAS ENTERED BY THE USER.

NOTE: TEMPERATURE DATA FOR HANFORD WASHINGTON

WAS ENTERED BY THE USER.

NOTE: SOLAR RADIATION DATA FOR HANFORD WASHINGTON

WAS ENTERED BY THE USER.

STATION LATITUDE $=46.30$ DEGREES 


\begin{tabular}{|c|c|c|c|}
\hline \multicolumn{4}{|c|}{ ANNUAL TOTALS FOR YEAR 70} \\
\hline & INCHES & CU. FEET & PERCENT \\
\hline PREC IPITATION & 6.33 & 1516542.120 & 100.00 \\
\hline RUNOFF & 0.345 & 82648.758 & 5.45 \\
\hline EVAPOTRANSPIRATION & 4.985 & 1194336.870 & 78.75 \\
\hline PERC. / LEAKAGE THROUGH LAYER 1 & 1.575345 & 377421.219 & 24.89 \\
\hline CHANGE IN WATER STORAGE & -0.575 & -137864.578 & -9.09 \\
\hline SOIL WATER AT START OF YEAR & 4.920 & 1178728.750 & \\
\hline SOIL WATER AT END OF YEAR & 4.345 & 1040864.120 & \\
\hline SNOW WATER AT START OF YEAR & 0.000 & 0.000 & 0.00 \\
\hline SNOW WATER AT END OF YEAR & 0.000 & 0.000 & 0.00 \\
\hline ANNUAL WATER BUDGET BALANCE & 0.0000 & -0.171 & 0.00 \\
\hline
\end{tabular}

ANNUAL TOTALS FOR YEAR 71

$\begin{array}{lcrc} & \text { INCHES } & \text { CU. FEET } & \text { PERCENT } \\ \text { PRECIPITATION } & 6.30 & 1509354.250 & 100.00 \\ \text { RUNOFF } & 0.066 & 15774.768 & 1.05 \\ \text { EVAPOTRANSPIRATION } & 5.757 & 1379151.620 & 91.37 \\ \text { PERC. /LEAKAGE THROUGH LAYER } & 0.388082 & 92976.766 & 6.16 \\ \text { CHANGE IN WATER STORAGE } & 0.090 & 21451.053 & 1.42 \\ \text { SOIL WATER AT START OF YEAR } & 4.345 & 1040864.120 & \\ \text { SOIL WATER AT END OF YEAR } & 4.410 & 1056559.370 & \\ \text { SNOW WATER AT START OF YEAR } & 0.000 & 0.000 & 0.00 \\ \text { SNOW WATER AT END OF YEAR } & 0.024 & 5755.759 & 0.38 \\ \text { ANNUAL WATER BUDGET BALANCE } & 0.0000 & 0.107 & 0.00\end{array}$




\begin{tabular}{|c|c|c|c|}
\hline \multicolumn{4}{|c|}{ ANNUAL TOTALS FOR YEAR 72} \\
\hline & INCHES & CU. FEET & PERCENT \\
\hline PREC IPITATION & 6.39 & 1530916.500 & 100.00 \\
\hline RUNOFF & 0.012 & 2868.375 & 0.19 \\
\hline EVAPOTRANSPIRATION & 5.535 & 1326055.750 & 86.62 \\
\hline PERC./LEAKAGE THROUGH LAYER & 0.386711 & 92648.133 & 6.05 \\
\hline CHANGE IN WATER STORAGE & 0.456 & 109344.437 & 7.14 \\
\hline SOIL WATER AT START OF YEAR & 4.410 & 1056559.370 & \\
\hline SOIL WATER AT END OF YEAR & 4.890 & 1171659.620 & \\
\hline SNOW WATER AT START OF YEAR & 0.024 & 5755.759 & 0.38 \\
\hline SNOW WATER AT END OF YEAR & 0.000 & 0.000 & 0.00 \\
\hline ANNUAL WATER BUDGET BALANCE & 0.0000 & -0.164 & 0.00 \\
\hline \multicolumn{4}{|c|}{ 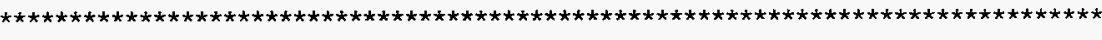 } \\
\hline \multicolumn{4}{|c|}{ 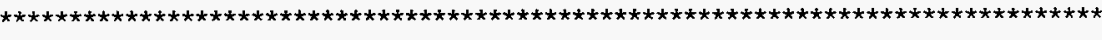 } \\
\hline ANNUA & AL TOTALS FOR YEAR & & \\
\hline & INCHES & CU. FEET & PERCENT \\
\hline PRECIPITATION & 8.27 & 1981327.000 & 100.00 \\
\hline RUNOFF & 0.091 & 21740.574 & 1.10 \\
\hline EVAPOTRANSPIRATION & 4.965 & 1189438.120 & 60.03 \\
\hline PERC./LEAKAGE THROUGH LAYER & 1.191387 & 285432.594 & 14.41 \\
\hline CHANGE IN WATER STORAGE & 2.023 & 484715.187 & 24.46 \\
\hline SOIL WATER AT START OF YEAR & 4.890 & 1171659.620 & \\
\hline SOIL WATER AT END OF YEAR & 6.459 & 1547464.870 & \\
\hline SNOW WATER AT START OF YEAR & 0.000 & 0.000 & 0.00 \\
\hline SNOW WATER AT END OF YEAR & 0.455 & 108909.969 & 5.50 \\
\hline ANNUAL WATER BUDGET BALANCE & 0.0000 & 0.486 & 0.00 \\
\hline
\end{tabular}




\begin{tabular}{|c|c|c|c|}
\hline \multicolumn{4}{|c|}{ ANNUAL TOTALS FOR YEAR 74} \\
\hline & INCHES & CU. FEET & PERCENT \\
\hline & $--1-n$ & --------- & ------ \\
\hline PRECIPITATION & 5.30 & 1269774.250 & 100.00 \\
\hline RUNOFF & 0.070 & 16853.326 & 1.33 \\
\hline EVAPOTRANSPIRATION & 5.222 & 1251206.000 & 98.54 \\
\hline PERC. /LEAKAGE THROUGH LAYER I & 1.856090 & 444682.125 & 35.02 \\
\hline CHANGE IN WATER STORAGE & -1.849 & -442966.750 & -34.89 \\
\hline SOIL WATER AT START OF YEAR & 6.459 & 1547464.870 & \\
\hline SOIL WATER AT END OF YEAR & 5.065 & 1213408.000 & \\
\hline SNOW WATER AT START OF YEAR & 0.455 & 108909.969 & 8.58 \\
\hline SNOW WATER AT END OF YEAR & 0.000 & 0.000 & 0.00 \\
\hline ANNUAL WATER BUDGET BALANCE & 0.0000 & -0.343 & 0.00 \\
\hline \multicolumn{4}{|c|}{ 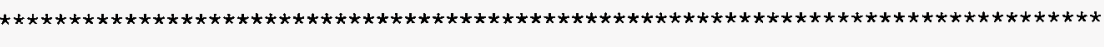 } \\
\hline \multicolumn{4}{|c|}{ 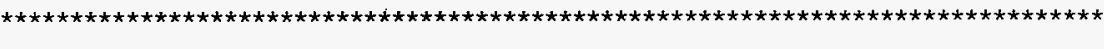 } \\
\hline ANNUAL & L TOTALS FOR YEAR & & \\
\hline & INCHES & CU. FEET & PERCENT \\
\hline PRECIPITATION & 7.73 & 1851953.500 & 100.00 \\
\hline RUNOFF & 0.033 & 8004.442 & 0.43 \\
\hline EVAPOTRANSPIRATION & 6.975 & 1670992.000 & 90.23 \\
\hline PERC./LEAKAGE THROUGH LAYER 1 & 0.965139 & 231227.906 & 12.49 \\
\hline CHANGE IN WATER STORAGE & -0.243 & -58270.156 & -3.15 \\
\hline SOIL WATER AT START OF YEAR & 5.065 & 1213408.000 & \\
\hline SOIL WATER AT END OF YEAR & 4.822 & 1155137.870 & \\
\hline SNOW WATER AT START OF YEAR & 0.000 & 0.000 & 0.00 \\
\hline SNOW WATER AT END OF YEAR & 0.000 & 0.000 & 0.00 \\
\hline ANNUAL WATER BUDGET BALANCE & 0.0000 & -0.671 & 0.00 \\
\hline
\end{tabular}




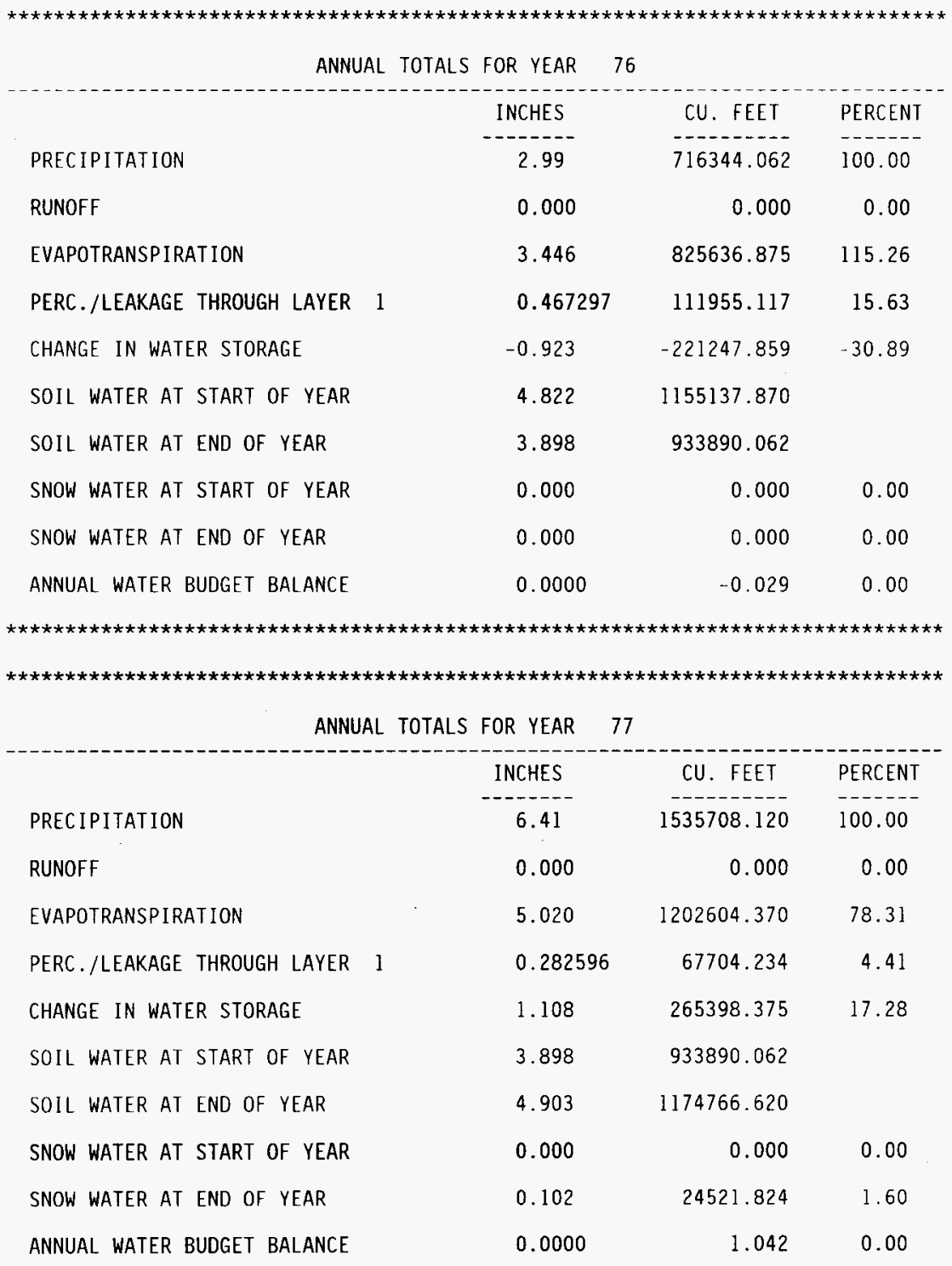




\begin{tabular}{|c|c|c|c|}
\hline \multicolumn{2}{|c|}{ ANNUAL TOTALS FOR YEAR } & 78 & \multirow{2}{*}{ PERCENT } \\
\hline & INCHES & CU. FEET & \\
\hline PREC I PITATION & 6.37 & 1526125.000 & \\
\hline & & & \\
\hline RUNOFF & 0.057 & 13698.763 & 0.90 \\
\hline EVAPOTRANSPIRATION & 6.004 & 1438435.620 & 94.25 \\
\hline PERC. / LEAKAGE THROUGH LAYER 1 & 0.695202 & 166556.516 & 10.91 \\
\hline CHANGE IN WATER STORAGE & -0.386 & -92565.953 & -6.07 \\
\hline SOIL WATER AT START OF YEAR & 4.903 & 1174766.620 & \\
\hline SOIL WATER AT END OF YEAR & 4.619 & 1106722.500 & \\
\hline SNOW WATER AT START OF YEAR & 0.102 & 24521.824 & 1.61 \\
\hline SNOW WATER AT END OF YEAR & 0.000 & 0.000 & 0.00 \\
\hline ANNUAL WATER BUDGET BALANCE & 0.0000 & 0.071 & 0.00 \\
\hline \multicolumn{4}{|c|}{ 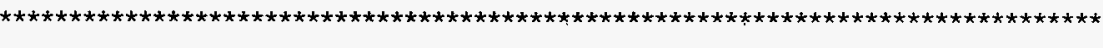 } \\
\hline \multicolumn{4}{|c|}{ 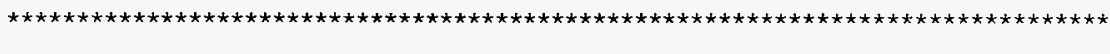 } \\
\hline ANNUAL & TOTALS FOR YEAR & & \\
\hline & INCHES & CU. FEET & PERCENT \\
\hline PRECIPITATION & 5.56 & 1332064.870 & 100.00 \\
\hline RUNOFF & 0.000 & 0.000 & 0.00 \\
\hline EVAPOTRANSPIRATION & 5.158 & 1235720.620 & 92.77 \\
\hline PERC./LEAKAGE THROUGH LAYER 1 & 0.327904 & 78559.172 & 5.90 \\
\hline CHANGE IN WATER STORAGE & 0.074 & 17784.584 & 1.34 \\
\hline SOIL WATER AT START OF YEAR & 4.619 & 1106722.500 & \\
\hline SOIL WATER AT END OF YEAR & 4.520 & 1082806.500 & \\
\hline SNOW WATER AT START OF YEAR & 0.000 & 0.000 & 0.00 \\
\hline SNOW WATER AT END OF YEAR & 0.174 & 41700.523 & 3.13 \\
\hline ANNUAL WATER BUDGET BALANCE & 0.0000 & 0.521 & 0.00 \\
\hline
\end{tabular}




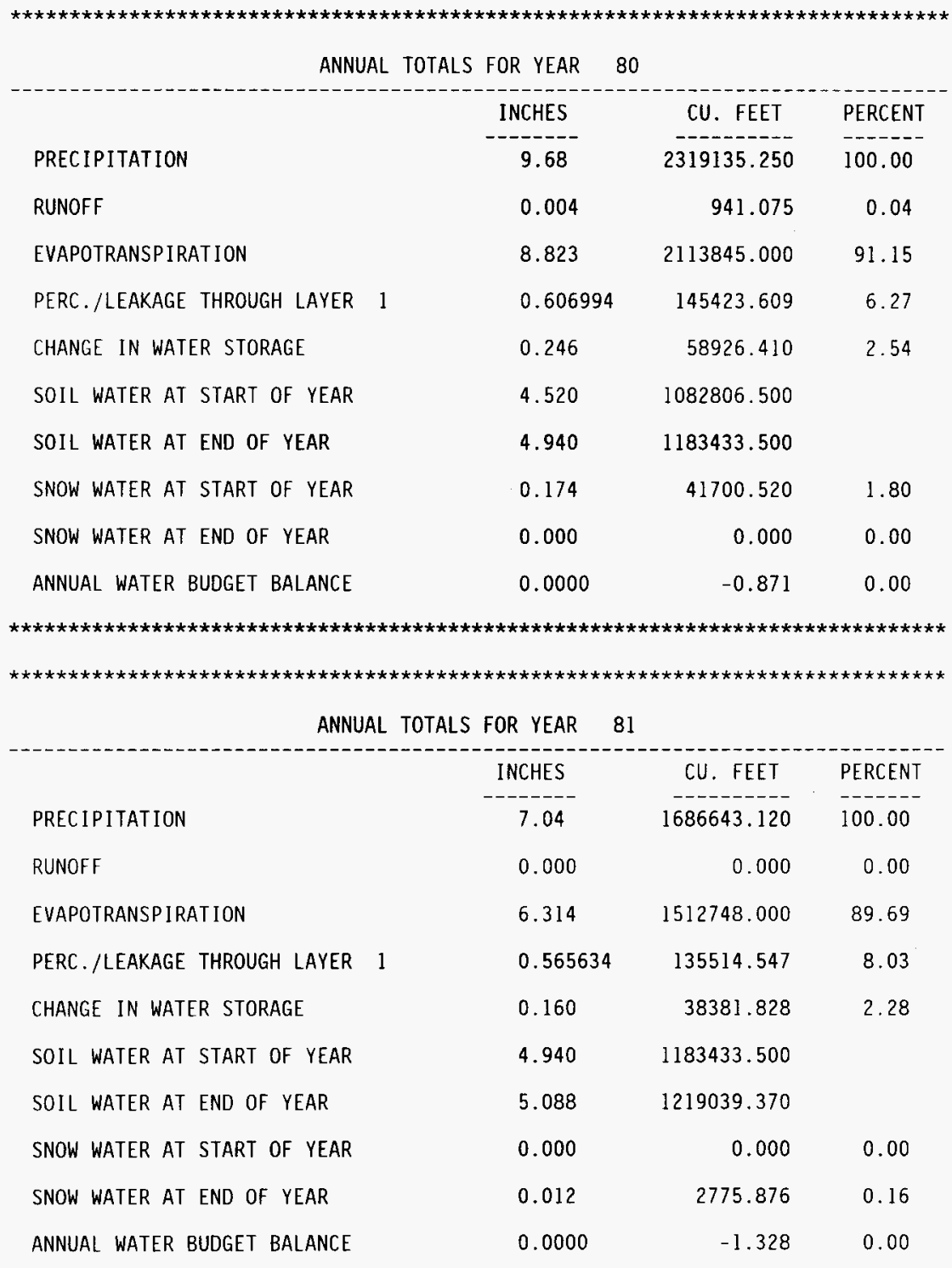




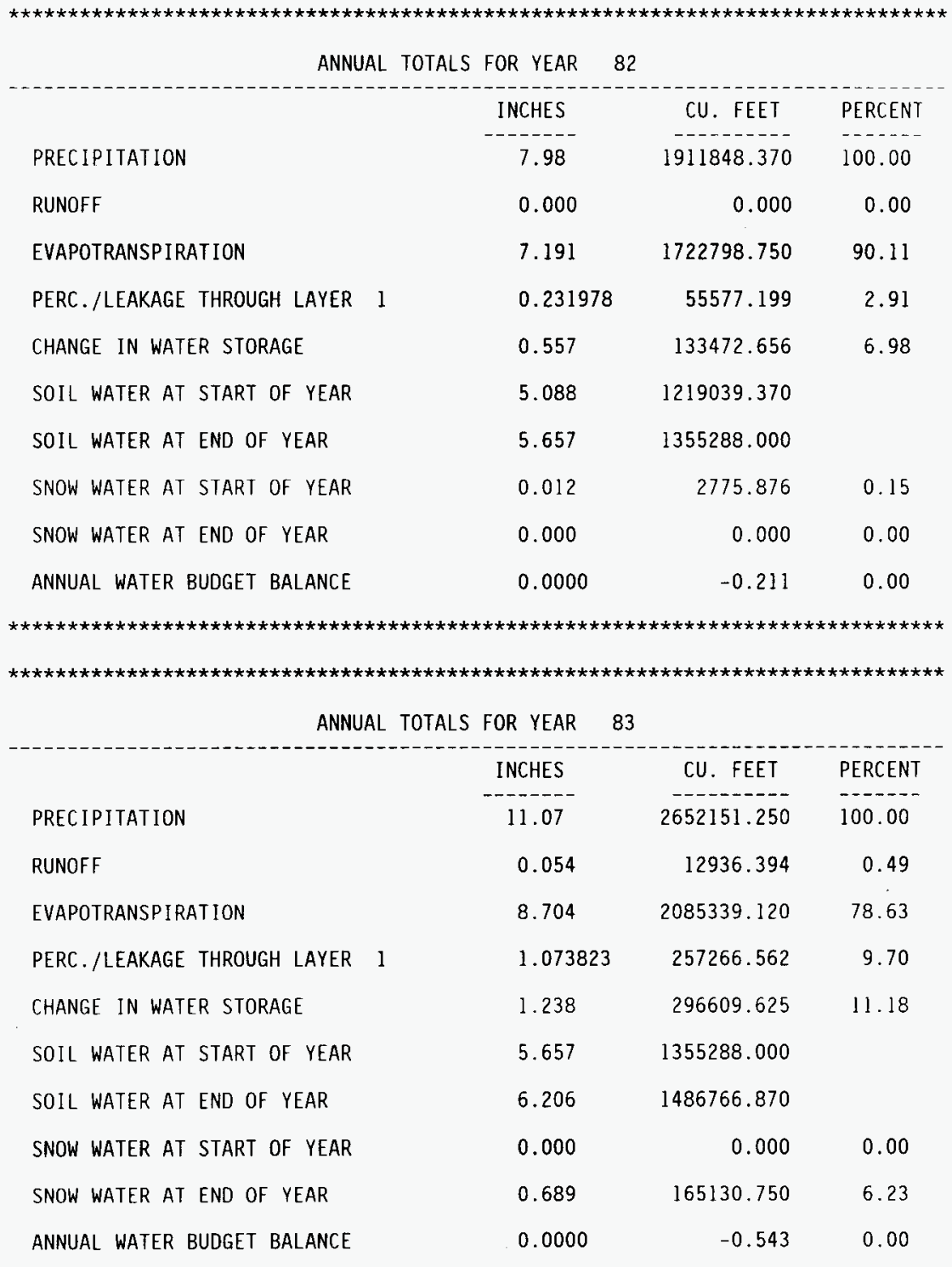




\begin{tabular}{|c|c|c|c|}
\hline \multicolumn{4}{|c|}{ ANNUAL TOTALS FOR YEAR 84} \\
\hline & INCHES & CU. FEET & PERCENT \\
\hline PRECIPITATION & 7.27 & 1741746.750 & 100.00 \\
\hline RUNOFF & 0.134 & 32084.047 & 1.84 \\
\hline EVAPOTRANSPIRATION & 7.334 & 1757081.500 & 100.88 \\
\hline PERC. / LEAKAGE THROUGH LAYER & 1.455160 & 348627.125 & 20.02 \\
\hline CHANGE IN WATER STORAGE & -1.653 & -396045.219 & -22.74 \\
\hline SOIL WATER AT START OF YEAR & 6.206 & 1486766.870 & \\
\hline SOIL WATER AT END OF YEAR & 5.171 & 1238878.500 & \\
\hline SNOW WATER AT START OF YEAR & 0.689 & 165130.750 & 9.48 \\
\hline SNOW WATER AT END OF YEAR & 0.071 & 16973.926 & 0.97 \\
\hline ANNUAL WATER BUDGET BALANCE & 0.0000 & -0.714 & 0.00 \\
\hline \multicolumn{4}{|c|}{ 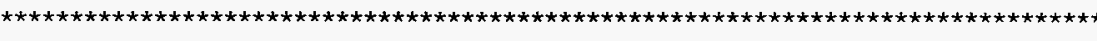 } \\
\hline \multicolumn{4}{|c|}{ 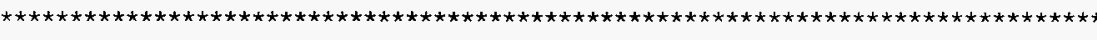 } \\
\hline \multicolumn{4}{|c|}{ ANNUAL TOTALS FOR YEAR 85} \\
\hline & INCHES & CU. FEET & PERCENT \\
\hline PREC IPITATION & 5.10 & 1221858.000 & 100.00 \\
\hline RUNOFF & 0.176 & 42178.383 & 3.45 \\
\hline EVAPOTRANSPIRATION & 4. 188 & 1003269.940 & 82.11 \\
\hline PERC. / LEAKAGE THROUGH LAYER & 0.493721 & 118285.641 & 9.68 \\
\hline CHANGE IN WATER STORAGE & 0.243 & 58124.156 & 4.76 \\
\hline SOIL WATER AT START OF YEAR & 5.171 & 1238878.500 & \\
\hline SOIL WATER AT END OF YEAR & 5.100 & 1221784.620 & \\
\hline SNOW WATER AT START OF YEAR & 0.071 & 16973.926 & 1.39 \\
\hline SNOW WATER AT END OF YEAR & 0.385 & 92191.906 & 7.55 \\
\hline ANNUAL WATER BUDGET BALANCE & 0.0000 & -0.129 & 0.00 \\
\hline
\end{tabular}


HELP, Version 3 , by EPA

Output File: COVER2.OUT

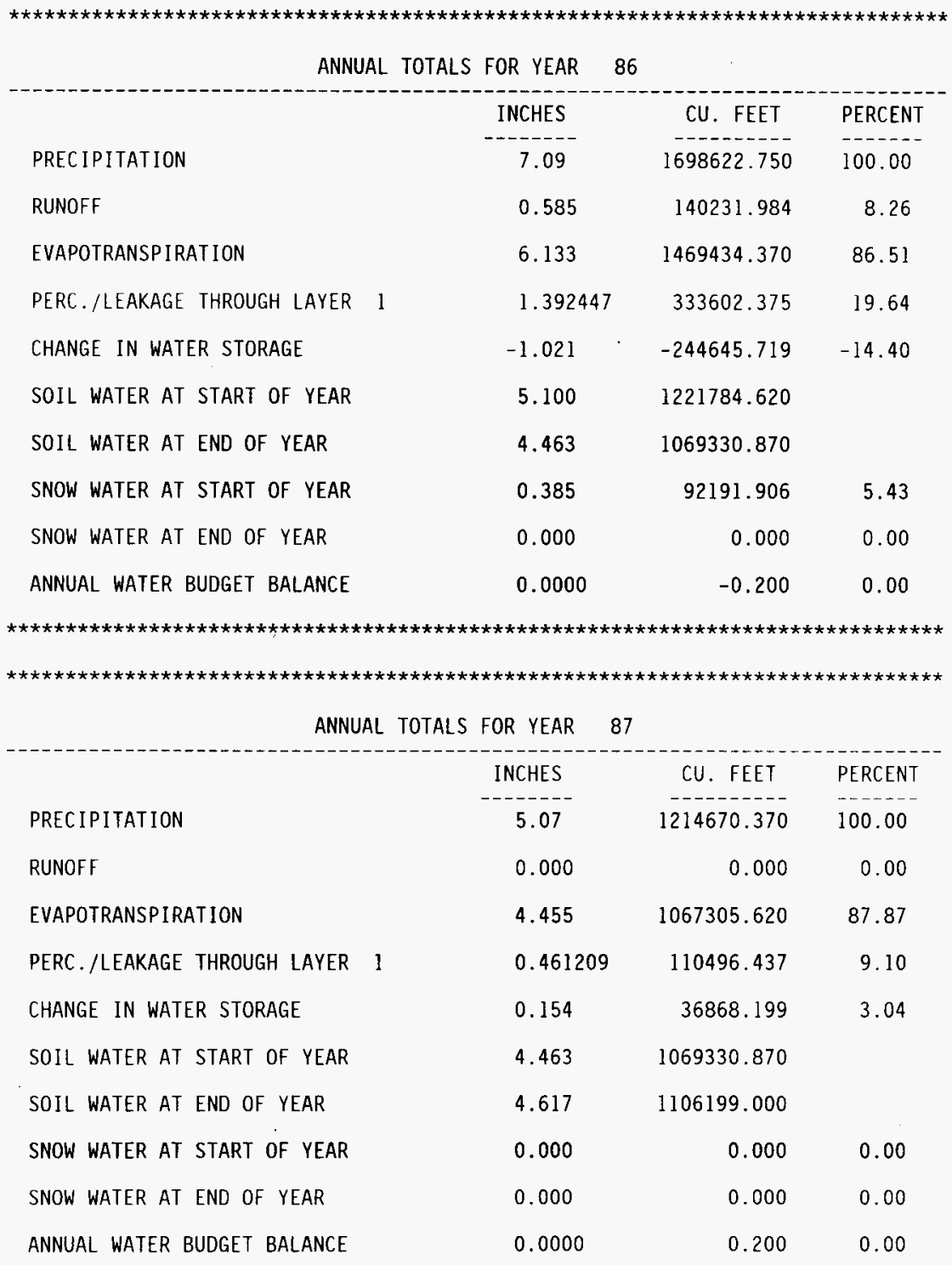




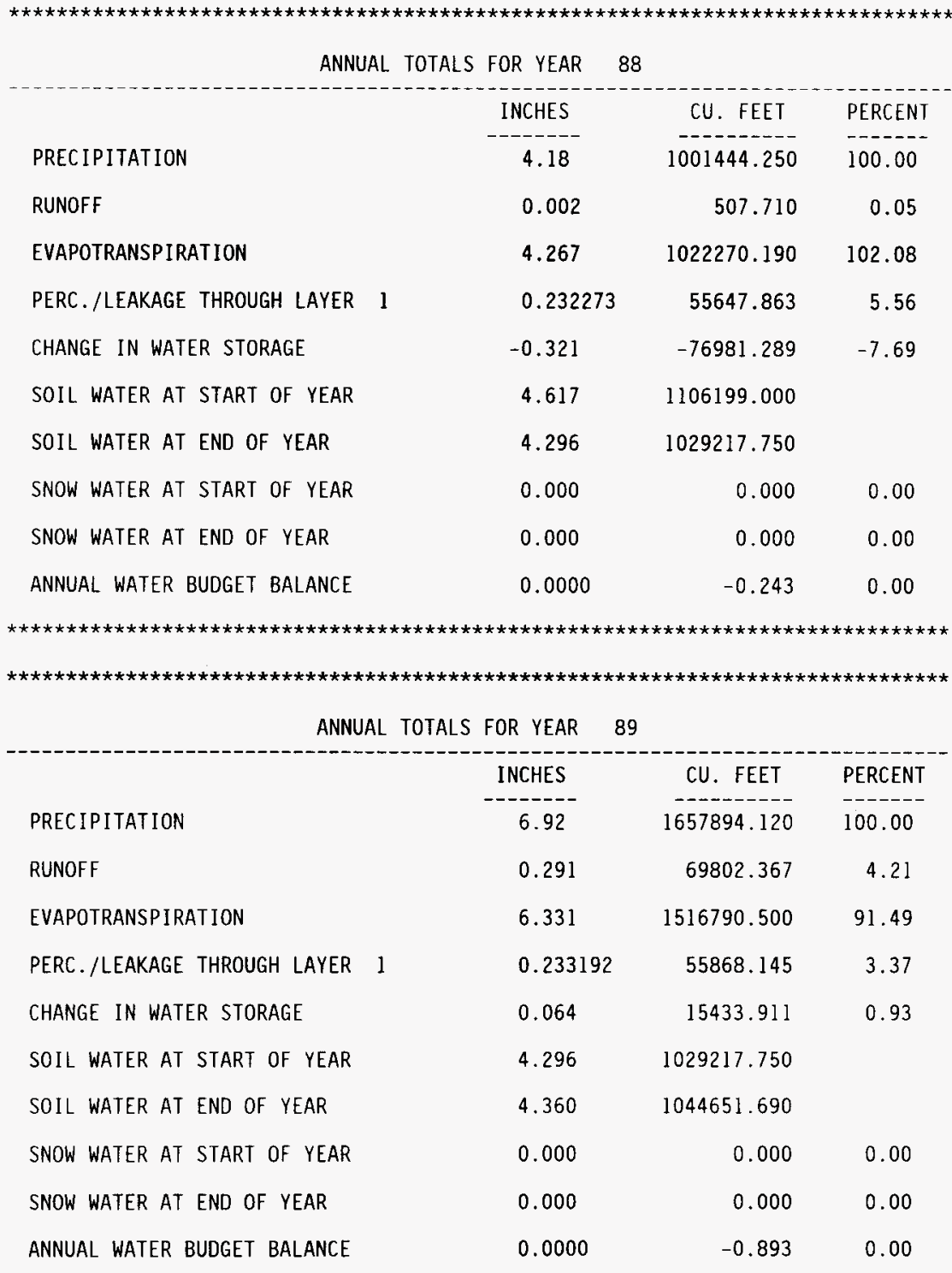




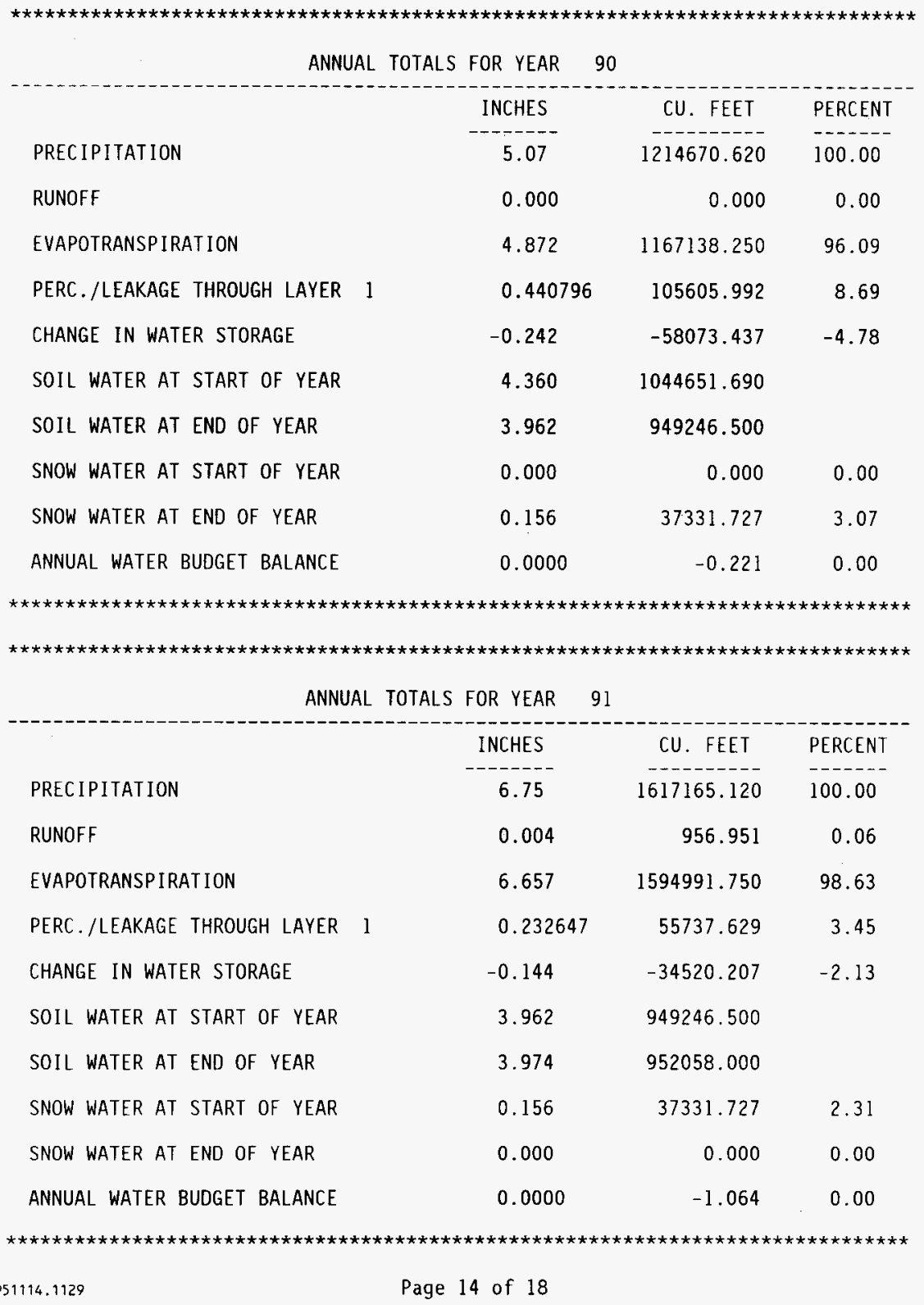




$\begin{array}{lrrr} & \text { ANNUAL TOTALS FOR YEAR } & 92 & \\ & \text { INCHES } & \text { CU. FEET } & \text { PERCENT } \\ \text { PRECIPITATION } & 7.90 & 1892682.250 & 100.00 \\ \text { RUNOFF } & 0.000 & 0.000 & 0.00 \\ \text { EVAPOTRANSPIRATION } & 6.300 & 1509361.250 & 79.75 \\ \text { PERC. /LEAKAGE THROUGH LAYER } & 1 & 44838.289 & 2.37 \\ \text { CHANGE IN WATER STORAGE } & 0.187154 & 338483.000 & 17.88 \\ \text { SOIL WATER AT START OF YEAR } & 1.413 & 952058.000 & \\ \text { SOIL WATER AT END OF YEAR } & 3.974 & 1143988.000 & 0.00 \\ \text { SNOW WATER AT START OF YEAR } & 4.775 & 0.000 & 7.74 \\ \text { SNOW WATER AT END OF YEAR } & 0.000 & 146553.000 & -0.293 \\ \text { ANNUAL WATER BUDGET BALANCE } & 0.612 & 0.0000 & 0.00\end{array}$

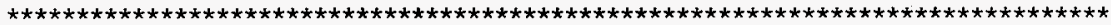
ANNUAL TOTALS FOR YEAR 93

$\begin{array}{lcrc} & \text { INCHES } & \text { CU. FEET } & \text { PERCENT } \\ \text { PRECIPITATION } & 7.83 & 1875911.620 & 100.00 \\ \text { RUNOFF } & 0.551 & 132070.828 & 7.04 \\ \text { EVAPOTRANSPIRATION } & 7.213 & 1728023.250 & 92.12 \\ \text { PERC. / LEAKAGE THROUGH LAYER } & 0.890705 & 213395.219 & 11.38 \\ \text { CHANGE IN WATER STORAGE } & -0.825 & -197577.109 & -10.53 \\ \text { SOIL WATER AT START OF YEAR } & 4.775 & 1143988.000 & \\ \text { SOIL WATER AT END OF YEAR } & 4.531 & 1085488.000 & 7.81 \\ \text { SNOW WATER AT START OF YEAR } & 0.612 & 146553.000 & 0.40 \\ \text { SNOW WATER AT END OF YEAR } & 0.031 & 7475.901 & 0.00 \\ \text { ANNUAL WATER BUDGET BALANCE } & 0.0000 & -0.543 & \\ \star & & & \end{array}$


HELP, Version 3, by EPA

Output File: COVER2. OUT

\begin{tabular}{|c|c|c|c|}
\hline ANNUAL & TOTALS FOR YEAR & 94 & \\
\hline & INCHES & CU. FEET & PERCENT \\
\hline PRECIPITATION & 6.12 & 1466230.120 & 100.00 \\
\hline RUNOFF & 0.000 & 0.000 & 0.00 \\
\hline EVAPOTRANSPIRATION & 5.262 & 1260693.870 & 85.98 \\
\hline PERC./LEAKAGE THROUGH LAYER 1 & 0.495539 & 118721.211 & 8.10 \\
\hline CHANGE IN WATER STORAGE & 0.362 & 86814.672 & 5.92 \\
\hline SOIL WATER AT START OF YEAR & 4.531 & 1085488.000 & \\
\hline SOIL WATER AT END OF YEAR & 4.924 & 1179778.620 & \\
\hline SNOW WATER AT START OF YEAR & 0.031 & 7475.901 & 0.51 \\
\hline SNOW WATER AT END OF YEAR & 0.000 & 0.000 & 0.00 \\
\hline ANNUAL WATER BUDGET BALANCE & 0.0000 & 0.407 & 0.00 \\
\hline
\end{tabular}




$\begin{array}{lcccccc} & \text { JAN/JUL } & \text { FEB/AUG } & \text { MAR/SEP } & \text { APR/OCT } & \text { MAY/NOV } & \text { JUN/DEC } \\ & & & & & & \\ \text { PRECIPITATION } & & & & & & \\ \text { TOTALS } & 0.82 & 0.64 & 0.55 & 0.43 & 0.54 & 0.42 \\ & 0.26 & 0.29 & 0.32 & 0.41 & 0.92 & 1.08 \\ \text { STD. DEVIATIONS } & 0.61 & 0.48 & 0.39 & 0.33 & 0.47 & 0.42 \\ & 0.36 & 0.39 & 0.34 & 0.37 & 0.68 & 0.60\end{array}$

RUNOFF

TOTALS

0.063

0.028

0.005

0.000

0.000

0.000

0.000

0.000

0.000

0.000

0.000

0.002

STD. DEVIATIONS

0.125
0.000

0.079

0.017

0.000

0.000

0.000

0.000

0.000

0.000

0.000

0.009

EVAPOTRANSPIRATION

-------------------

TOTALS

0.681

0.725

0.679

0.444

0.363

0.286

0.273

0.231

0.549

0.454

STD. DEVIATIONS

$\begin{array}{llllll}0.294 & 0.385 & 0.430 & 0.224 & 0.477 & 0.342 \\ 0.298 & 0.212 & 0.303 & 0.156 & 0.371 & 0.274\end{array}$

PERCOLATION/LEAKAGE THROUGH LAYER 1

$\begin{array}{lllllll}\text { TOTALS } & 0.0615 & 0.0508 & 0.0609 & 0.0790 & 0.0691 & 0.0583 \\ & 0.0521 & 0.0446 & 0.0444 & 0.0486 & 0.0498 & 0.0662 \\ \text { STD. DEVIATIONS } & & & & & & \\ & 0.0911 & 0.0605 & 0.0518 & 0.0961 & 0.0701 & 0.0563 \\ & 0.0405 & 0.0321 & 0.0493 & 0.0402 & 0.0427 & 0.1384\end{array}$




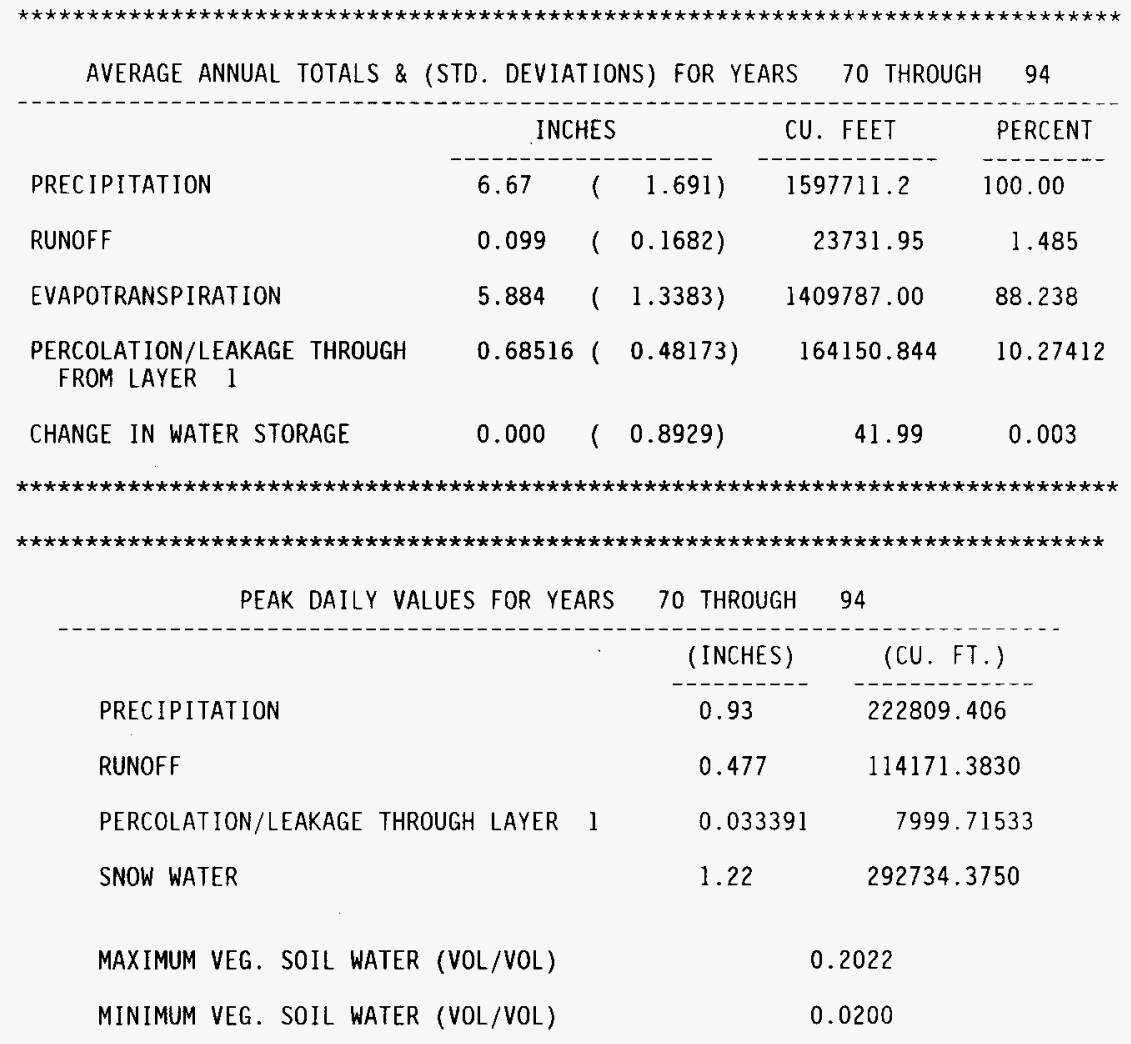

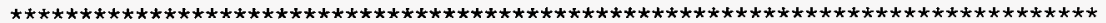

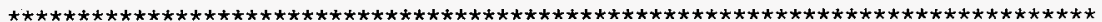

FINAL WATER STORAGE AT END OF YEAR 94

$\begin{array}{ccc}\text { LAYER } & \text { (INCHES) } & (\mathrm{V} 0 \mathrm{~L} / \mathrm{V} 0 \mathrm{~L}) \\ -1 & 4.9248 & 0.1026\end{array}$

SNOW WATER $\quad 0.000$ 


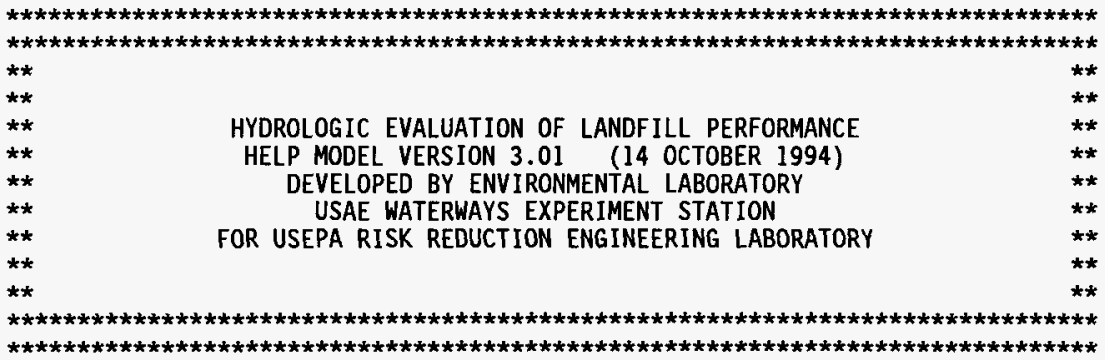
PRECIPITATION DATA FILE:
C: \HELP3\HNFDPRCP.D4
TEMPERATURE DATA FILE:
C: $\backslash$ HELP3 \HNFDTEMP.D7
SOLAR RADIATION DATA FILE: C: \HELP3\HNFDSUN.D13
EVAPOTRANSPIRATION DATA: C: \HELP3\HNFDEVAP.DI1
SOIL AND DESIGN DATA FILE: C: \HELP3 \NOCOVER1.D10
OUTPUT DATA FILE:
$C: \backslash$ HELP3\COVER3. OUT

TIME: $11: 10 \quad$ DATE: $11 / 14 / 1995$

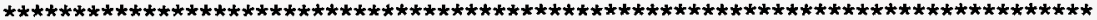

TITLE: Solid Waste Landfill - Operational Cover, C.Sand, Poor Grass 
NOTE: INITIAL MOISTURE CONTENT OF THE LAYERS AND SNOW WATER WERE SPECIFIED BY THE USER.

LAYER 1

TYPE 1 - VERTICAL PERCOLATION LAYER

THICKNESS

MATERIAL TEXTURE NUMBER 1

POROSITY

48.00 INCHES

FIELD CAPACITY

$=$

$\begin{array}{ll}= & 0.4170 \mathrm{VOL} / \mathrm{VOL} \\ = & 0.0450 \mathrm{VOL} / \mathrm{VOL}\end{array}$

WILTING POINT

$=\quad 0.0180 \mathrm{VOL} / \mathrm{VOL}$

INITIAL SOIL WATER CONTENT $=0.0580 \mathrm{VOL} / \mathrm{VOL}$

EFFECTIVE SAT. HYD. COND. $=0.999999978000 \mathrm{E}-02 \mathrm{CM} / \mathrm{SEC}$

NOTE: SATURATED HYDRAULIC CONDUCTIVITY IS MULTIPLIED BY 2.49

FOR ROOT CHANNELS IN TOP HALF OF EVAPORATIVE ZONE.

GENERAL DESIGN AND EVAPORATIVE ZONE DATA

NOTE: SCS RUNOFF CURVE NUMBER WAS COMPUTED FROM DEFAULT SOIL DATA BASE USING SOIL TEXTURE \# 1 WITH A POOR STAND OF GRASS, A SURFACE SLOPE OF $2 . \%$ AND A SLOPE LENGTH OF 500. FEET.

SCS RUNOFF CURVE NUMBER

FRACTION OF AREA ALLOWING RUNOFF=

AREA PROJECTED ON HORIZONTAL PLANE =

EVAPORATIVE ZONE DEPTH

INITIAL WATER IN EVAPORATIVE ZONE =

UPPER LIMIT OF EVAPORATIVE STORAGE =

LOWER LIMIT OF EVAPORATIVE STORAGE =

INITIAL SNOW WATER

INITIAL WATER IN LAYER MATERIALS =

TOTAL INITIAL WATER

62.20

90.0

$=66.000$

$=32.0$

1.856

13.344

0.576

0.000

2.784

2.784

TOTAL SUBSURFACE INFLOW

$=\quad 0.00$ INCHES/YEAR 
EVAPOTRANSPIRATION AND WEATHER DATA

NOTE: EVAPOTRANSPIRATION DATA WAS OBTAINED FROM Hanford Washington

MAXIMUM LEAF AREA INDEX $\quad=1.60$

START OF GROWING SEASON (JULIAN DATE) $=103$

END OF GROWING SEASON (JULIAN DATE) $=290$

AVERAGE ANNUAL WIND SPEED $=7.50 \mathrm{MPH}$

AVERAGE IST QUARTER RELATIVE HUMIDITY $=68.60 \%$

AVERAGE 2ND QUARTER RELATIVE HUMIDITY $=43.20 \%$

AVERAGE 3RD QUARTER RELATIVE HUMIDITY $=37.90 \%$

AVERAGE 4TH QUARTER RELATIVE HUMIDITY $=69.40 \%$

NOTE: PRECIPITATION DATA FOR HANFORD WASHINGTON WAS ENTERED BY THE USER.

NOTE: TEMPERATURE DATA FOR HANFORD WASHINGTON WAS ENTERED BY THE USER.

NOTE: SOLAR RADIATION DATA FOR HANFORD WASHINGTON WAS ENTERED BY THE USER.

STATION LATITUDE $=46.30$ DEGREES 


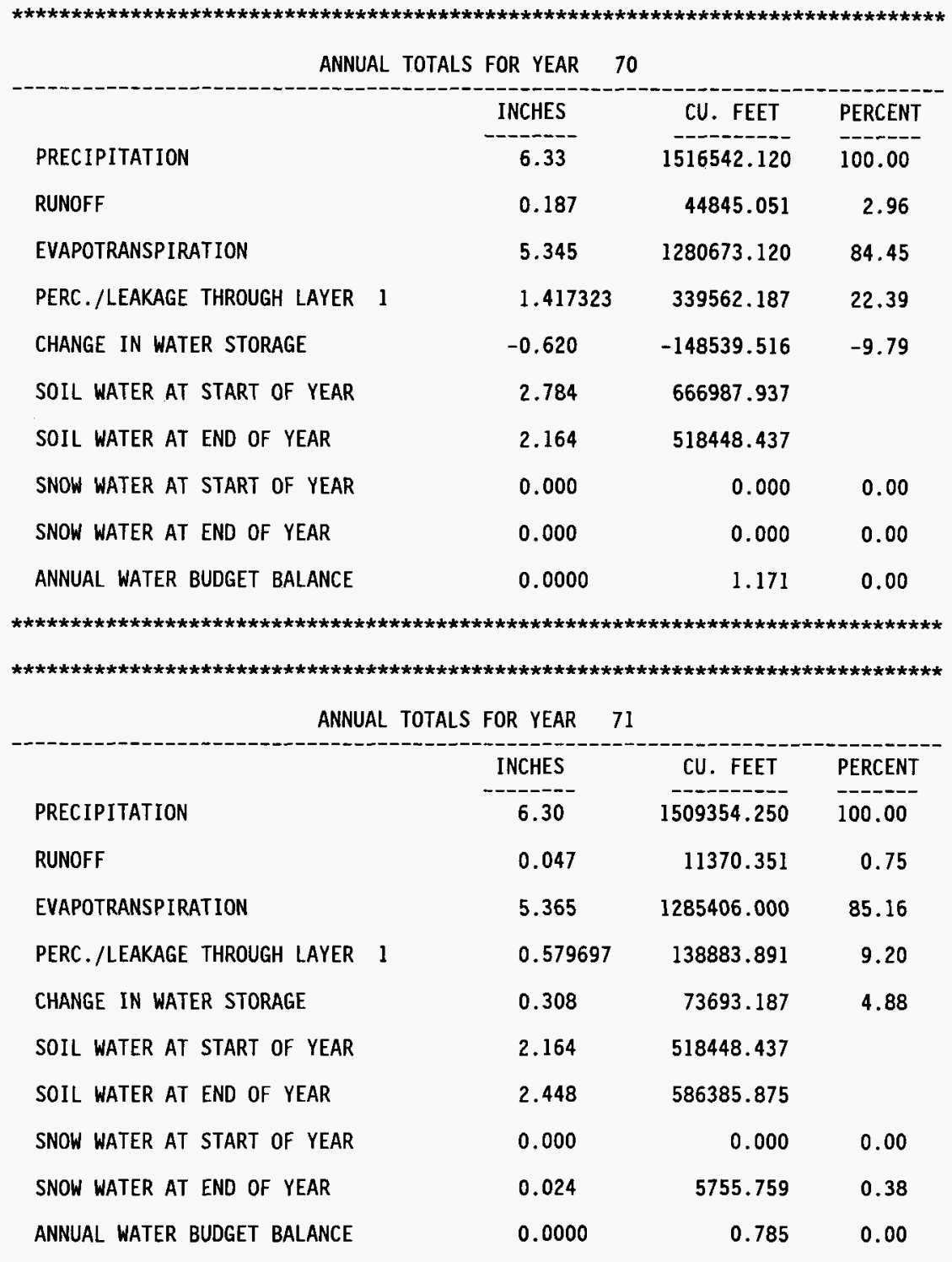




\begin{tabular}{|c|c|c|c|}
\hline ANNUAL & L TOTALS FOR YEAR & 72 & \\
\hline & INCHES & CU. FEET & PERCENT \\
\hline PRECIPITATION & 6.39 & 1530916.500 & 100.00 \\
\hline RUNOFF & 0.002 & 394.224 & 0.03 \\
\hline EVAPOTRANSPIRATION & 5.660 & 1356092.870 & 88.58 \\
\hline PERC./LEAKAGE THROUGH LAYER & 0.618491 & 148178.094 & 9.68 \\
\hline CHANGE IN WATER STORAGE & 0.110 & 26250.129 & 1.71 \\
\hline SOIL WATER AT START OF YEAR & 2.448 & 586385.875 & \\
\hline SOIL WATER AT END OF YEAR & 2.581 & 618391.750 & \\
\hline SNOW WATER AT START OF YEAR & 0.024 & 5755.759 & 0.38 \\
\hline SNOW WATER AT END OF YEAR & 0.000 & 0.000 & 0.00 \\
\hline ANNUAL WATER BUDGET BALANCE & 0.0000 & 1.157 & 0.00 \\
\hline
\end{tabular}

ANNUAL TOTALS FOR YEAR 73

\begin{tabular}{|c|c|c|c|}
\hline & INCHES & CU. FEET & PERCENT \\
\hline PRECIPITATION & 8.27 & 1981327.000 & 100.00 \\
\hline RUNOFF & 0.045 & 10689.562 & 0.54 \\
\hline EVAPOTRANSPIRATION & 5.493 & 1316019.750 & 66.42 \\
\hline PERC./LEAKAGE THROUGH LAYER 1 & 0.248425 & 59517.738 & 3.00 \\
\hline CHANGE IN WATER STORAGE & 2.484 & 595099.437 & 30.04 \\
\hline SOIL WATER AT START OF YEAR & 2.581 & 618391.750 & \\
\hline SOIL WATER AT END OF YEAR & 4.610 & 1104581.250 & \\
\hline SNOW WATER AT START OF YEAR & 0.000 & 0.000 & 0.00 \\
\hline SNOW WATER AT END OF YEAR & 0.455 & 108909.969 & 5.50 \\
\hline ANNUAL WATER BUDGET BALANCE & 0.0000 & 0.468 & 0.00 \\
\hline
\end{tabular}




\begin{tabular}{|c|c|c|c|}
\hline \multicolumn{4}{|c|}{ ANNUAL TOTALS FOR YEAR } \\
\hline & INCHES & CU. FEET & PERCENT \\
\hline PRECIPITATION & 5.30 & 1269774.250 & 100.00 \\
\hline RUNOFF & 0.052 & 12409.278 & 0.98 \\
\hline EVAPOTRANSPIRATION & 6.674 & 1598893.750 & 125.92 \\
\hline PERC./LEAKAGE THROUGH LAYER & 1.593488 & 381767.969 & 30.07 \\
\hline CHANGE IN WATER STORAGE & -3.019 & -723297.375 & -56.96 \\
\hline SOIL WATER AT START OF YEAR & 4.610 & 1104581.250 & \\
\hline SOIL WATER AT END OF YEAR & 2.046 & 490193.875 & \\
\hline SNOW WATER AT START OF YEAR & 0.455 & 108909.969 & 8.58 \\
\hline SNOW WATER AT END OF YEAR & 0.000 & 0.000 & 0.00 \\
\hline ANNUAL WATER BUDGET BALANCE & 0.0000 & 0.714 & 0.00 \\
\hline ANNUAL & L TOTALS FOR YEAR & 75 & \\
\hline & INCHES & CU. FEET & PERCENT \\
\hline PRECIPITATION & 7.73 & 1851953.500 & 100.00 \\
\hline RUNOFF & 0.026 & 6252.904 & 0.34 \\
\hline EVAPOTRANSPIRATION & 6.847 & 1640496.500 & 88.58 \\
\hline PERC./LEAKAGE THROUGH LAYER & 0.443482 & 106249.305 & 5.74 \\
\hline CHANGE IN WATER STORAGE & 0.413 & 98954.680 & 5.34 \\
\hline SOIL WATER AT START OF YEAR & 2.046 & 490193.875 & \\
\hline SOIL WATER AT END OF YEAR & 2.459 & 589148.562 & \\
\hline SNOW WATER AT START OF YEAR & 0.000 & 0.000 & 0.00 \\
\hline SNOW WATER AT END OF YEAR & 0.000 & 0.000 & 0.00 \\
\hline ANNUAL WATER BUDGET BALANCE & 0.0000 & 0.150 & 0.00 \\
\hline
\end{tabular}




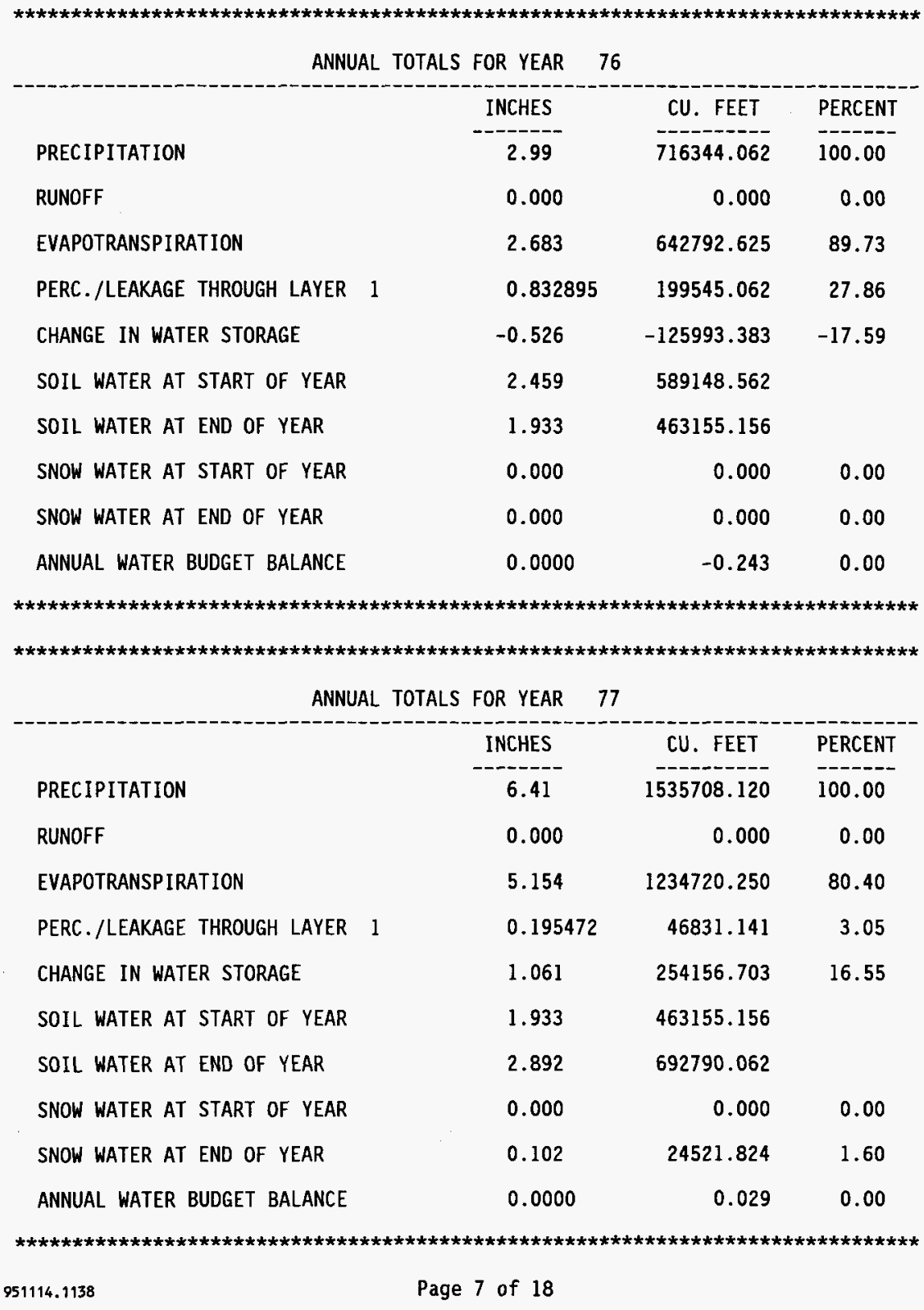




\begin{tabular}{|c|c|c|c|}
\hline ANNUAL & TOTALS FOR YEAR & 78 & \\
\hline & INCHES & CU. FEET & PERCENT \\
\hline PRECIPITATION & 6.37 & 1526125.000 & 100.00 \\
\hline RUNOFF & 0.031 & 7435.947 & 0.49 \\
\hline EVAPOTRANSPIRATION & 6.498 & 1556835.500 & 102.01 \\
\hline PERC./LEAKAGE THROUGH LAYER 1 & 0.630815 & 151130.609 & 9.90 \\
\hline CHANGE IN WATER STORAGE & -0.790 & -189278.031 & -12.40 \\
\hline SOIL WATER AT START OF YEAR & 2.892 & 692790.062 & \\
\hline SOIL WATER AT END OF YEAR & 2.204 & 528033.875 & \\
\hline SNOW WATER AT START OF YEAR & 0.102 & 24521.824 & 1.61 \\
\hline SNOW WATER AT END OF YEAR & 0.000 & 0.000 & 0.00 \\
\hline ANNUAL WATER BUDGET BALANCE & 0.0000 & 0.957 & 0.00 \\
\hline
\end{tabular}

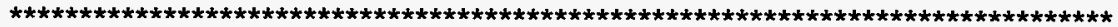

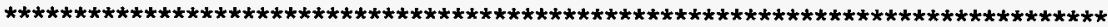
ANNUAL TOTALS FOR YEAR 79

$\begin{array}{lrrr} & \text { INCHES } & \text { CU. FEET } & \text { PERCENT } \\ \text { PRECIPITATION } & 5.56 & 1332064.870 & 100.00 \\ \text { RUNOFF } & 0.000 & 0.000 & 0.00 \\ \text { EVAPOTRANSPIRATION } & 4.827 & 1156544.250 & 86.82 \\ \text { PERC. /LEAKAGE THROUGH LAYER } 1 & 0.282149 & 67597.172 & 5.07 \\ \text { CHANGE IN WATER STORAGE } & 0.450 & 107923.023 & 8.10 \\ \text { SOIL WATER AT START OF YEAR } & 2.204 & 528033.875 & \\ \text { SOIL WATER AT END OF YEAR } & 2.480 & 594256.375 & \\ \text { SNOW WATER AT START OF YEAR } & 0.000 & 0.000 & 0.00 \\ \text { SNOW WATER AT END OF YEAR } & 0.174 & 41700.523 & 3.13 \\ \text { ANNUAL WATER BUDGET BALANCE } & 0.0000 & 0.500 & 0.00\end{array}$




\begin{tabular}{|c|c|c|c|}
\hline \multicolumn{2}{|c|}{ ANNUAL TOTALS FOR YEAR } & 80 & \multirow[b]{2}{*}{ PERCENT } \\
\hline & INCHES & CU. FEET & \\
\hline PRECIPITATION & 9.68 & 2319135.250 & 100.00 \\
\hline RUNOFF & 0.001 & 192.460 & 0.01 \\
\hline EVAPOTRANSPIRATION & 8.854 & 2121123.500 & 91.46 \\
\hline PERC./LEAKAGE THROUGH LAYER 1 & 0.722561 & 173111.187 & 7.46 \\
\hline CHANGE IN WATER STORAGE & 0.103 & 24707.625 & 1.07 \\
\hline SOIL WATER AT START OF YEAR & 2.480 & 594256.375 & \\
\hline SOIL WATER AT END OF YEAR & 2.758 & 660664.500 & \\
\hline SNOW WATER AT START OF YEAR & 0.174 & 41700.520 & 1.80 \\
\hline SNOW WATER AT END OF YEAR & 0.000 & 0.000 & 0.00 \\
\hline ANNUAL WATER BUDGET BALANCE & 0.0000 & 0.428 & 0.00 \\
\hline \multicolumn{4}{|c|}{ 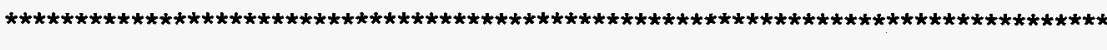 } \\
\hline \multicolumn{4}{|c|}{ 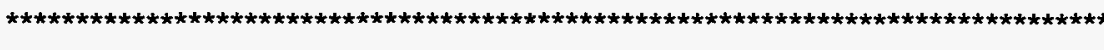 } \\
\hline ANNUAL & L TOTALS FOR YEAR & 81 & \\
\hline & INCHES & CU. FEET & PERCENT \\
\hline PRECIPITATION & 7.04 & 1686643.120 & 100.00 \\
\hline RUNOFF & 0.000 & 0.000 & 0.00 \\
\hline EVAPOTRANSPIRATION & 5.899 & 1413373.370 & 83.80 \\
\hline PERC./LEAKAGE THROUGH LAYER I & 0.940613 & 225352.141 & 13.36 \\
\hline CHANGE IN WATER STORAGE & 0.200 & 47917.609 & 2.84 \\
\hline SOIL WATER AT START OF YEAR & 2.758 & 660664.500 & \\
\hline SOIL WATER AT END OF YEAR & 2.946 & 705806.250 & \\
\hline SNOW WATER AT START OF YEAR & 0.000 & 0.000 & 0.00 \\
\hline SNOW WATER AT END OF YEAR & 0.012 & 2775.876 & 0.16 \\
\hline ANNUAL WATER BUDGET BALANCE & 0.0000 & -0.071 & 0.00 \\
\hline
\end{tabular}




\begin{tabular}{|c|c|c|c|}
\hline ANNUAL & L TOTALS FOR YEAR & 82 & \\
\hline & INCHES & CU. FEET & PERCENT \\
\hline PRECIPITATION & 7.98 & 1911848.370 & 100.00 \\
\hline RUNOFF & 0.000 & 0.000 & 0.00 \\
\hline EVAPOTRANSPIRATION & 6.829 & 1636056.620 & 85.57 \\
\hline PERC. /LEAKAGE THROUGH LAYER 1 & 0.603713 & 144637.484 & 7.57 \\
\hline CHANGE IN WATER STORAGE & 0.547 & 131154.437 & 6.86 \\
\hline SOIL WATER AT START OF YEAR & 2.946 & 705806.250 & \\
\hline SOIL WATER AT END OF YEAR & 3.505 & 839736.562 & \\
\hline SNOW WATER AT START OF YEAR & 0.012 & 2775.876 & 0.15 \\
\hline SNOW WATER AT END OF YEAR & 0.000 & 0.000 & 0.00 \\
\hline ANNUAL WATER BUDGET BALANCE & 0.0000 & -0.143 & 0.00 \\
\hline
\end{tabular}

\begin{tabular}{|c|c|c|c|}
\hline ANNUAL & L TOTALS FOR YEAR & 83 & \\
\hline & INCHES & CU. FEET & PERCENT \\
\hline PRECIPITATION & 11.07 & 2652151.250 & 100.00 \\
\hline RUNOFF & 0.045 & 10691.567 & 0.40 \\
\hline EVAPOTRANSPIRATION & 8.972 & 2149468.500 & 81.05 \\
\hline PERC./LEAKAGE THROUGH LAYER 1 & 1.062103 & 254458.609 & 9.59 \\
\hline CHANGE IN WATER STORAGE & 0.991 & 237531.391 & 8.96 \\
\hline SOIL WATER AT START OF YEAR & 3.505 & 839736.562 & \\
\hline SOIL WATER AT END OF YEAR & 3.807 & 912137.187 & \\
\hline SNOW WATER AT START OF YEAR & 0.000 & 0.000 & 0.00 \\
\hline SNOW WATER AT END OF YEAR & 0.689 & 165130.750 & 6.23 \\
\hline ANNUAL WATER BUDGET BALANCE & 0.0000 & 1.028 & 0.00 \\
\hline
\end{tabular}




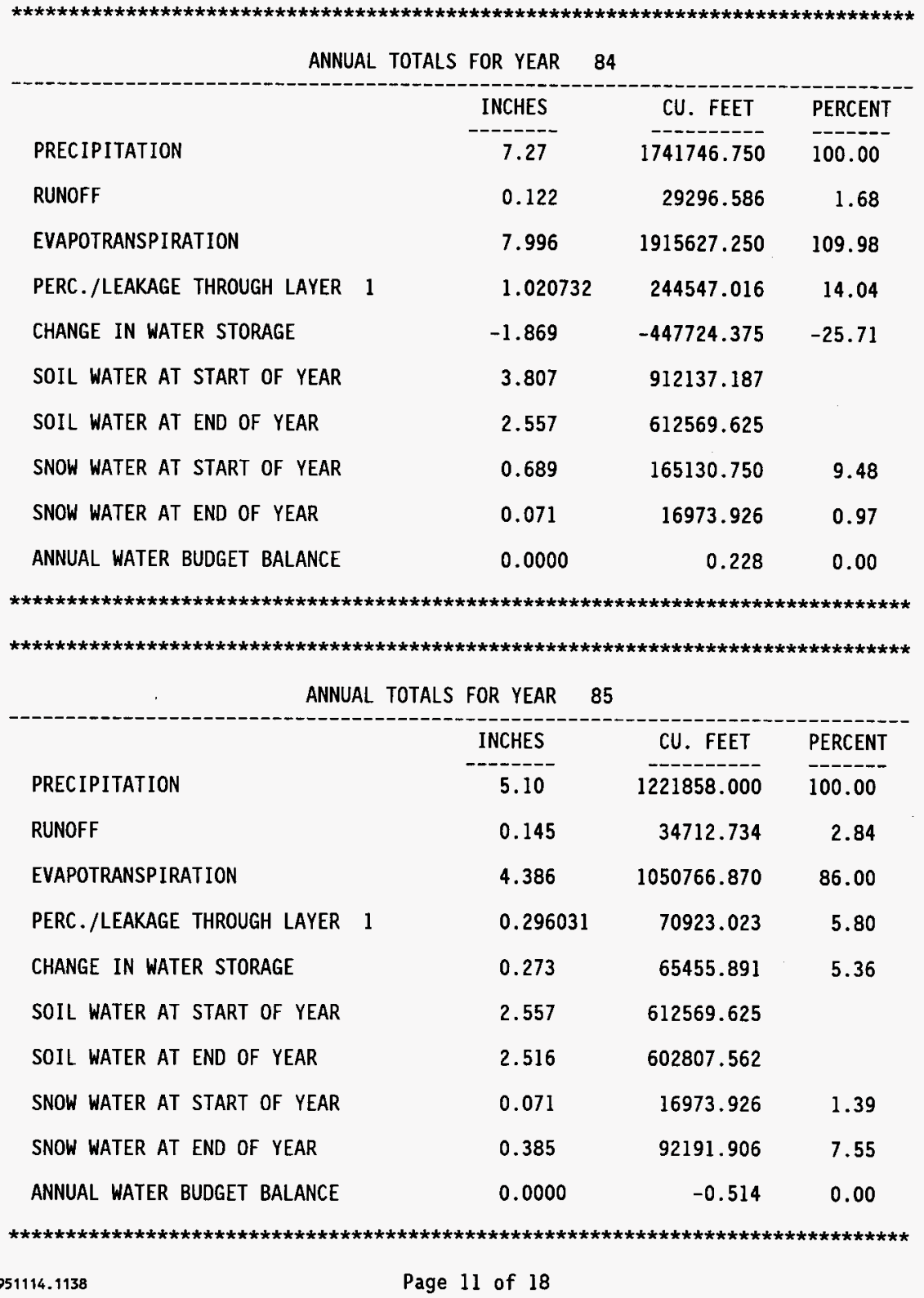




\begin{tabular}{|c|c|c|c|}
\hline ANNUAL & L TOTALS FOR YEAR & 86 & \\
\hline & INCHES & CU. FEET & PERCENT \\
\hline PRECIPITATION & 7.09 & 1698622.750 & 100.00 \\
\hline RUNOFF & 0.276 & 66196.539 & 3.90 \\
\hline EVAPOTRANSPIRATION & 6.055 & 1450757.370 & 85.41 \\
\hline PERC. /LEAKAGE THROUGH LAYER 1 & 1.631025 & 390761.062 & 23.00 \\
\hline CHANGE IN WATER STORAGE & -0.873 & -209092.766 & -12.31 \\
\hline SOIL WATER AT START OF YEAR & 2.516 & 602807.562 & \\
\hline SOIL WATER AT END OF YEAR & 2.028 & 485906.719 & \\
\hline SNOW WATER AT START OF YEAR & 0.385 & 92191.906 & 5.43 \\
\hline SNOW WATER AT END OF YEAR & 0.000 & 0.000 & 0.00 \\
\hline ANNUAL WATER BUDGET BALANCE & 0.0000 & 0.571 & 0.00 \\
\hline
\end{tabular}

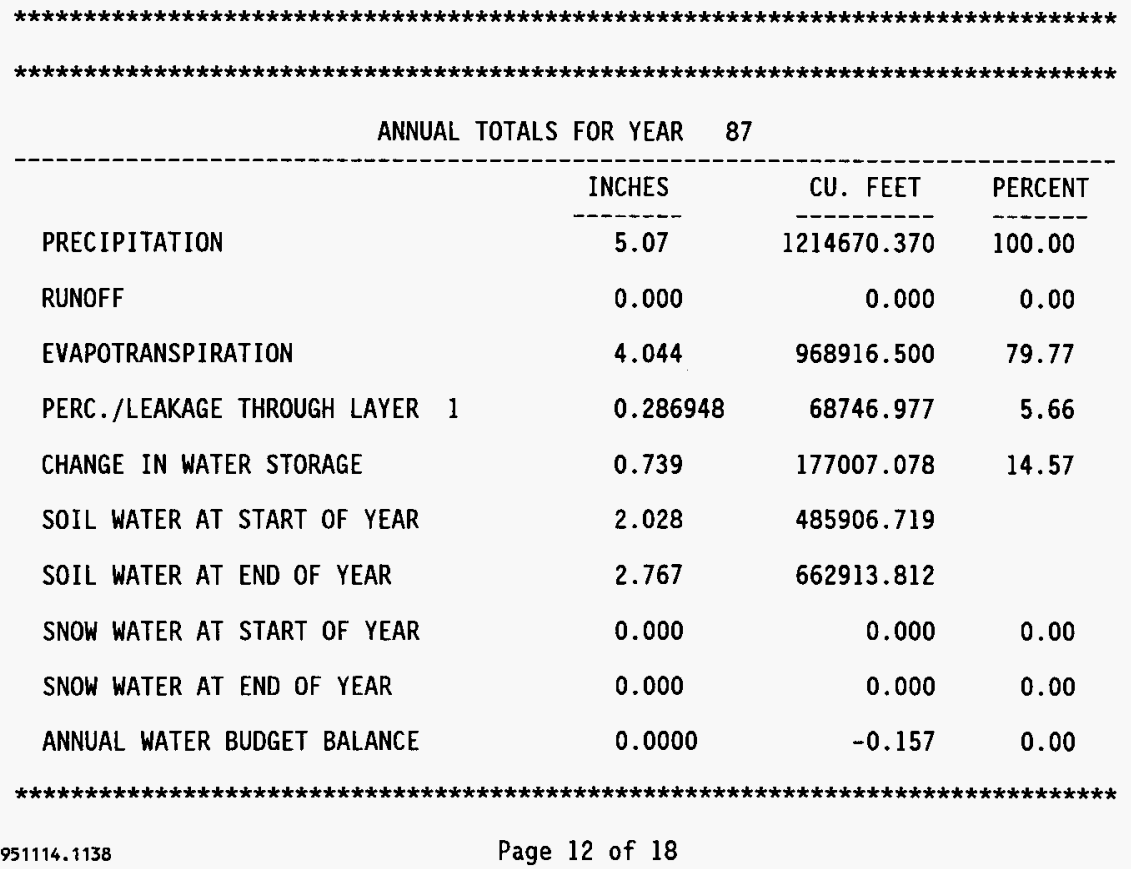




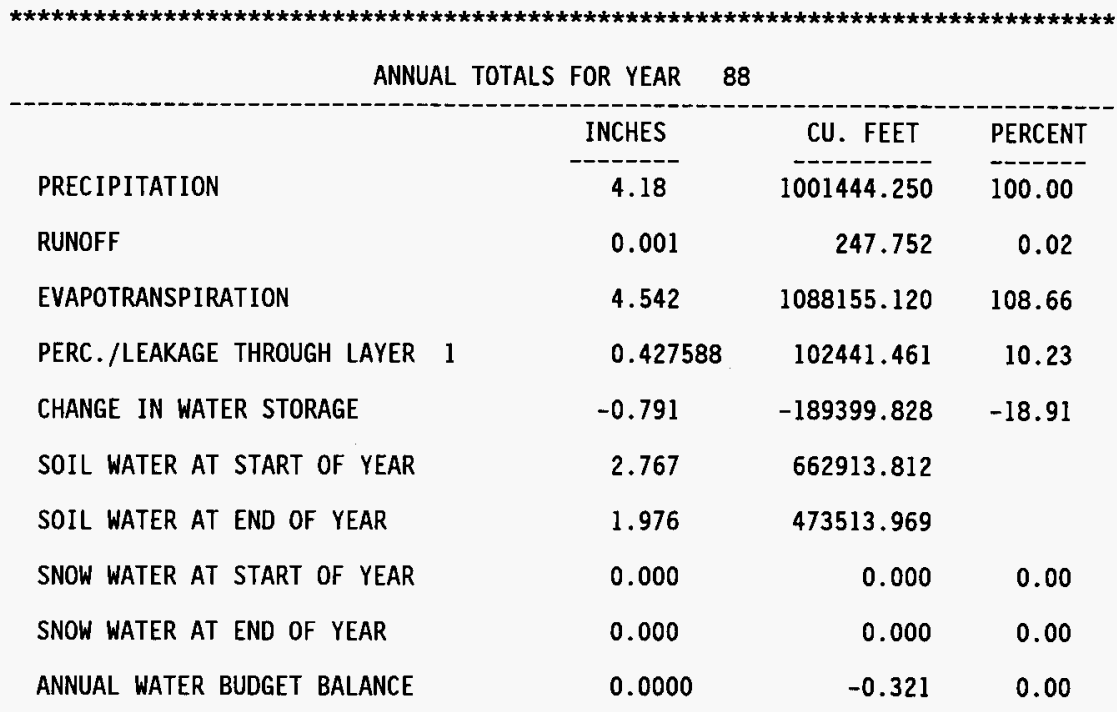

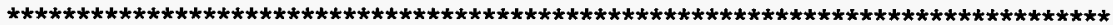

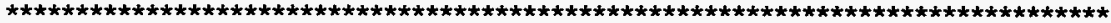
ANNUAL TOTALS FOR YEAR 89

$\begin{array}{lcrc} & \text { INCHES } & \text { CU. FEET } & \text { PERCENT } \\ \text { PRECIPITATION } & -1.92 & 1657894.120 & 100.00 \\ \text { RUNOFF } & 0.143 & 34357.531 & 2.07 \\ \text { EVAPOTRANSPIRATION } & 6.386 & 1529952.500 & 92.28 \\ \text { PERC. /LEAKAGE THROUGH LAYER } 1 & 0.480642 & 115152.117 & 6.95 \\ \text { CHANGE IN WATER STORAGE } & -0.090 & -21568.205 & -1.30 \\ \text { SOIL WATER AT START OF YEAR } & 1.976 & 473513.969 & \\ \text { SOIL WATER AT END OF YEAR } & 1.886 & 451945.750 & 0.000 \\ \text { SNOW WATER AT START OF YEAR } & 0.000 & 0.000 & 0.00 \\ \text { SNOW WATER AT END OF YEAR } & 0.000 & 0.086 & 0.00\end{array}$




\begin{tabular}{|c|c|c|c|}
\hline \multicolumn{4}{|c|}{ ANNUAL TOTALS FOR YEAR 90} \\
\hline & INCHES & CU. FEET & PERCENT \\
\hline PRECIPITATION & 5.07 & 1214670.620 & 100.00 \\
\hline RUNOFF & 0.000 & 0.000 & 0.00 \\
\hline EVAPOTRANSPIRATION & 4.473 & 1071620.500 & 88.22 \\
\hline PERC./LEAKAGE THROUGH LAYER & 0.282495 & 67680.211 & 5.57 \\
\hline CHANGE IN WATER STORAGE & 0.315 & 75369.812 & 6.20 \\
\hline SOIL WATER AT START OF YEAR & 1.886 & 451945.750 & \\
\hline SOIL WATER AT END OF YEAR & 2.045 & 489983.844 & \\
\hline SNOW WATER AT START OF YEAR & 0.000 & 0.000 & 0.00 \\
\hline SNOW WATER AT END OF YEAR & 0.156 & 37331.727 & 3.07 \\
\hline ANNUAL WATER BUDGET BALANCE & 0.0000 & 0.057 & 0.00 \\
\hline ANNUAL & L TOTALS FOR YEAR & 91 & \\
\hline & INCHES & CU. FEET & PERCENT \\
\hline PRECIPITATION & 6.75 & 1617165.120 & 100.00 \\
\hline RUNOFF & 0.002 & 436.619 & 0.03 \\
\hline EVAPOTRANSPIRATION & 6.330 & 1516523.370 & 93.78 \\
\hline PERC./LEAKAGE THROUGH LAYER & 0.481661 & 115396.344 & 7.14 \\
\hline CHANGE IN WATER STORAGE & -0.063 & -15190.918 & -0.94 \\
\hline SOIL WATER AT START OF YEAR & 2.045 & 489983.844 & \\
\hline SOIL WATER AT END OF YEAR & 2.138 & 512124.656 & \\
\hline SNOW WATER AT START OF YEAR & 0.156 & 37331.727 & 2.31 \\
\hline SNOW WATER AT END OF YEAR & 0.000 & 0.000 & 0.00 \\
\hline ANNUAL WATER BUDGET BALANCE & 0.0000 & -0.257 & 0.00 \\
\hline
\end{tabular}




\begin{tabular}{|c|c|c|c|}
\hline ANNUAL & L TOTALS FOR YEAR & 92 & \\
\hline & INCHES & CU. FEET & PERCENT \\
\hline PRECIPITATION & 7.90 & 1892682.250 & 100.00 \\
\hline RUNOFF & 0.000 & 0.000 & 0.00 \\
\hline EVAPOTRANSPIRATION & 5.746 & 1376742.250 & 72.74 \\
\hline PERC./LEAKAGE THROUGH LAYER 1 & 0.792726 & 189921.266 & 10.03 \\
\hline CHANGE IN WATER STORAGE & 1.361 & 326018.156 & 17.23 \\
\hline SOIL WATER AT START OF YEAR & 2.138 & 512124.656 & \\
\hline SOIL WATER AT END OF YEAR & 2.887 & 691589.812 & \\
\hline SNOW WATER AT START OF YEAR & 0.000 & 0.000 & 0.00 \\
\hline SNOW WATER AT END OF YEAR & 0.612 & 146553.000 & 7.74 \\
\hline ANNUAL WATER BUDGET BALANCE & 0.0000 & 0.585 & 0.00 \\
\hline
\end{tabular}

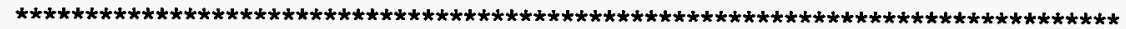

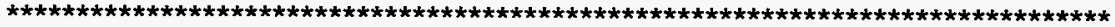
ANNUAL TOTALS FOR YEAR 93

$\begin{array}{lccc} & \text { INCHES } & \text { CU. FEET } & \text { PERCENT } \\ \text { PRECIPITATION } & -1.83 & 1875911.620 & 100.00 \\ \text { RUNOFF } & 0.467 & 111858.187 & 5.96 \\ \text { EVAPOTRANSPIRATION } & 8.318 & 1992857.250 & 106.23 \\ \text { PERC. /LEAKAGE THROUGH LAYER } 1 & 0.624766 & 149681.375 & 7.98 \\ \text { CHANGE IN WATER STORAGE } & -1.580 & -378485.469 & -20.18 \\ \text { SOIL WATER AT START OF YEAR } & 2.887 & 691589.812 & \\ \text { SOIL WATER AT END OF YEAR } & 1.887 & 452181.437 & \\ \text { SNOW WATER AT START OF YEAR } & 0.612 & 146553.000 & 7.81 \\ \text { SNOW WATER AT END OF YEAR } & 0.031 & 7475.901 & 0.40 \\ \text { ANNUAL WATER BUDGET BALANCE } & 0.0000 & 0.257 & 0.00\end{array}$




\begin{tabular}{|c|c|c|c|}
\hline ANNUAL & TOTALS FOR YEAR & 94 & \\
\hline & INCHES & CU. FEET & PERCENT \\
\hline PRECIPITATION & 6.12 & 1466230.120 & 100.00 \\
\hline RUNOFF & 0.000 & 0.000 & 0.00 \\
\hline EVAPOTRANSPIRATION & 5.032 & 1205560.120 & 82.22 \\
\hline PERC./LEAKAGE THROUGH LAYER I & 0.203940 & 48859.879 & 3.33 \\
\hline CHANGE IN WATER STORAGE & 0.884 & 211809.984 & 14.45 \\
\hline SOIL WATER AT START OF YEAR & 1.887 & 452181.437 & \\
\hline SOIL WATER AT END OF YEAR & 2.803 & 671467.312 & \\
\hline SNOW WATER AT START OF YEAR & 0.031 & 7475.901 & 0.51 \\
\hline SNOW WATER AT END OF YEAR & 0.000 & 0.000 & 0.00 \\
\hline ANNUAL WATER BUDGET BALANCE & 0.0000 & 0.096 & 0.00 \\
\hline
\end{tabular}




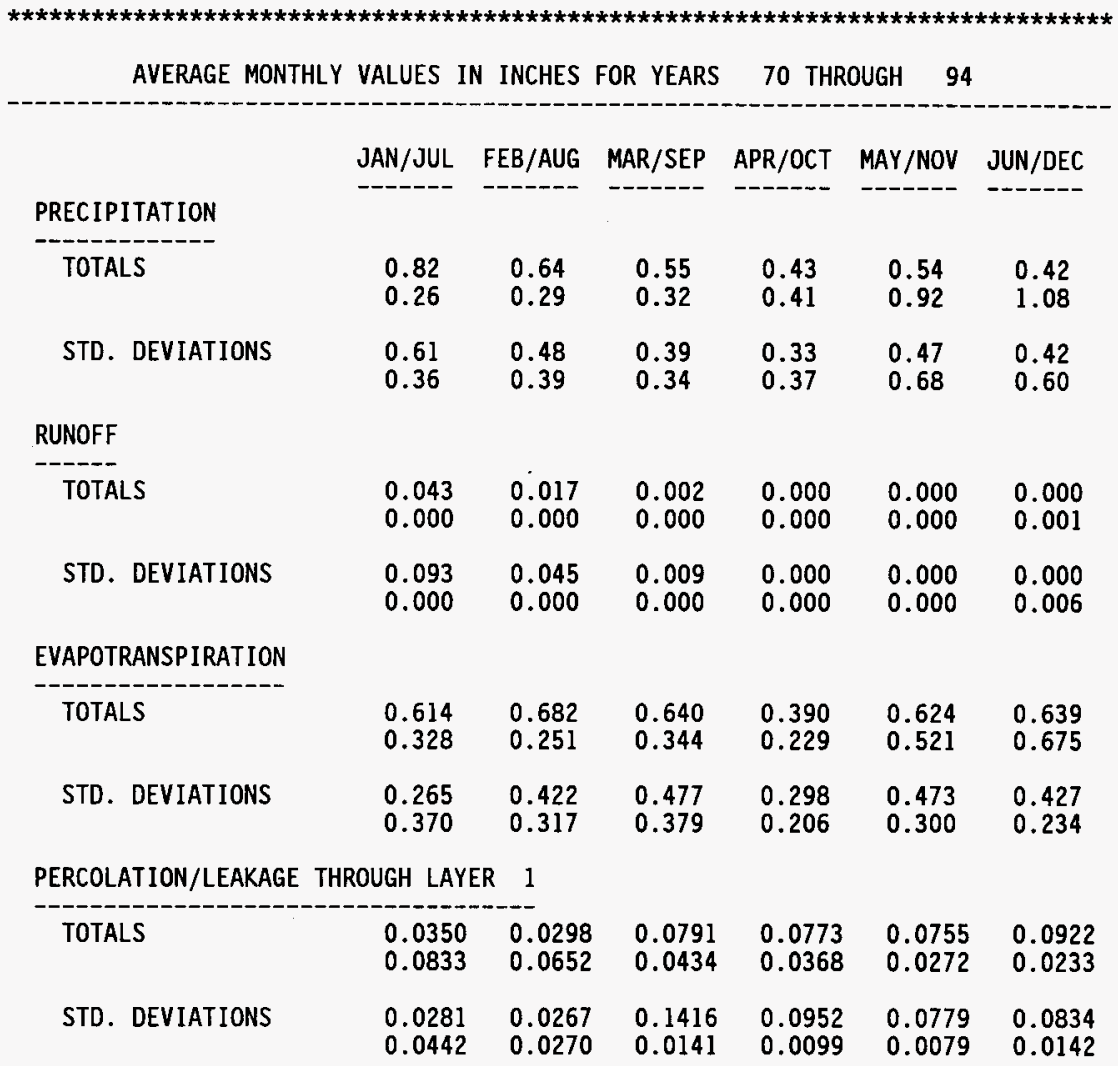




\begin{tabular}{|c|c|c|c|c|c|}
\hline AVERAGE ANNUAL TOTALS \& & (STD. DEVIATI & IONS) FOR Y & ARS & 70 THROUGH & 94 \\
\hline \multirow[b]{2}{*}{ PRECIPITATION } & \multicolumn{2}{|c|}{ INCHES } & \multicolumn{2}{|c|}{ CU. FEET } & \multirow{2}{*}{$\begin{array}{c}\text { PERCENT } \\
100.00\end{array}$} \\
\hline & 6.67 & $(1.691)$ & & 97711.2 & \\
\hline RUNOFF & 0.064 & $(0.1109)$ & & 15255.49 & 0.955 \\
\hline EVAPOTRANSPIRATION & 5.936 & $(1.5110)$ & & 22238.87 & 89.017 \\
\hline $\begin{array}{l}\text { PERCOLATION/LEAKAGE THROUGH } \\
\text { FROM LAYER I }\end{array}$ & 0.66799( & $(0.41516)$ & & 60037.344 & 10.01666 \\
\hline CHANGE IN WATER STORAGE & 0.001 & $(1.1226)$ & & 179.17 & 0.011 \\
\hline
\end{tabular}

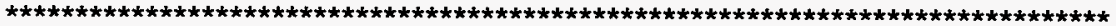

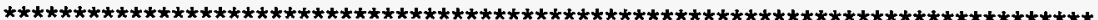
PEAK DAILY VALUES FOR YEARS 70 THROUGH 94

\begin{tabular}{llc} 
& (INCHES) & (CU. FT.) \\
PRECIPITATION & 0.93 & 222809.406 \\
RUNOFF & 0.420 & 100572.8670 \\
PERCOLATION/LEAKAGE THROUGH LAYER 1 & 0.040118 & 9611.38184 \\
SNOW WATER & 1.22 & 292734.3750 \\
MAXIMUM VEG. SOIL WATER (VOL/VOL) & & 0.1176 \\
MINIMUM VEG. SOIL WATER (VOL/VOL) & \multicolumn{2}{c}{0.0130}
\end{tabular}

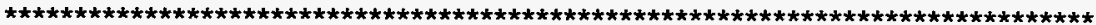

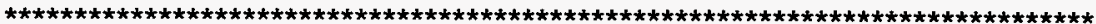
FINAL WATER STORAGE AT END OF YEAR 94

\begin{tabular}{lcc} 
LAYER & (INCHES) & $(\mathrm{VOL} / \mathrm{VOL})$ \\
\hdashline 1 & 2.8032 & 0.0584
\end{tabular}

SNOW WATER $\quad 0.000$

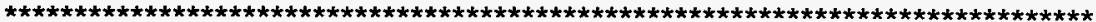

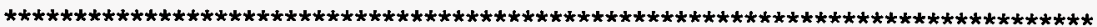




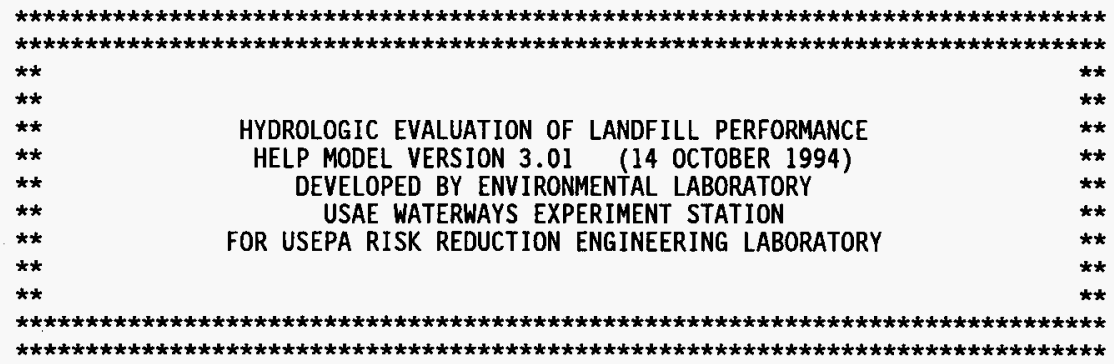

PRECIPITATION DATA FILE: $\quad$ C: \HELP3 \HNFDPRCP.D4

TEMPERATURE DATA FILE: $\quad$ C: \HELP3\HNFDTEMP.D7

SOLAR RADIATION DATA FILE: C: \HELP3\HNFDSUN.D13

EVAPOTRANSPIRATION DATA: $\quad C: \backslash H E L P 3 \backslash H N F D E V A P . D 11$

SOIL AND DESIGN DATA FILE: C: \HELP3 \NOCOVER2.D10

OUTPUT DATA FILE: $\quad C:$ \HELP3\COVER4.OUT

TIME: $11: 13 \quad$ DATE: $11 / 14 / 1995$

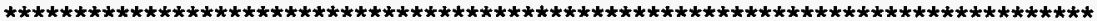

TITLE: Solid Waste Landfill - Operational Cover, M.Sand, Poor Grass

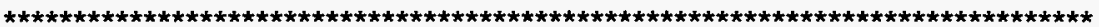


NOTE: INITIAL MOISTURE CONTENT OF THE LAYERS AND SNOW WATER WERE SPECIFIED BY THE USER.

\author{
LAYER 1 \\ TYPE 1 - VERTICAL PERCOLATION LAYER \\ MATERIAL TEXTURE NUMBER 2 \\ THICKNESS \\ POROSITY \\ 48.00 INCHES \\ FIELD CAPACITY $\quad=0.0620 \mathrm{VOL} / \mathrm{VOL}$ \\ WILTING POINT $=0.0240 \mathrm{VOL} / \mathrm{VOL}$ \\ INITIAL SOIL WATER CONTENT $=0.0770 \mathrm{VOL} / \mathrm{VOL}$ \\ EFFECTIVE SAT. HYD. COND. $=0.579999993000 \mathrm{E}-02 \mathrm{CM} / \mathrm{SEC}$ \\ NOTE: SATURATED HYDRAULIC CONDUCTIVITY IS MULTIPLIED BY 2.49 \\ FOR ROOT CHANNELS IN TOP HALF OF EVAPORATIVE ZONE.
}

GENERAL DESIGN AND EVAPORATIVE ZONE DATA

NOTE: SCS RUNOFF CURVE NUMBER WAS COMPUTED FROM DEFAULT SOIL DATA BASE USING SOIL TEXTURE \# 2 WITH A POOR STAND OF GRASS, A SURFACE SLOPE OF 2.\% AND A SLOPE LENGTH OF 500. FEET.

$\begin{array}{llll}\text { SCS RUNOFF CURVE NUMBER } & = & 71.50 & \\ \text { FRACTION OF AREA ALLOWING RUNOFF } & = & 90.0 & \text { PERCENT } \\ \text { AREA PROJECTED ON HORIZONTAL PLANE } & = & 66.000 & \text { ACRES } \\ \text { EVAPORATIVE ZONE DEPTH } & = & 32.0 & \text { INCHES } \\ \text { INITIAL WATER IN EVAPORATIVE ZONE } & = & 2.464 & \text { INCHES } \\ \text { UPPER LIMIT OF EVAPORATIVE STORAGE } & = & 13.984 & \text { INCHES } \\ \text { LOWER LIMIT OF EVAPORATIVE STORAGE } & = & 0.768 & \text { INCHES } \\ \text { INITIAL SNOW WATER } & = & 0.000 & \text { INCHES } \\ \text { INITIAL WATER IN LAYER MATERIALS } & = & 3.696 & \text { INCHES } \\ \text { TOTAL INITIAL WATER } & = & 3.696 & \text { INCHES } \\ \text { TOTAL SUBSURFACE INFLOW } & = & 0.00 & \text { INCHES/YEAR }\end{array}$


NOTE: EVAPOTRANSPIRATION DATA WAS OBTAINED FROM Hanford Washington

$\begin{array}{ll}\text { MAXIMUM LEAF AREA INDEX } & =1.60 \\ \text { START OF GROWING SEASON (JUL IAN DATE) } & =103 \\ \text { END OF GROWING SEASON (JULIAN DATE) } & =290 \\ \text { AVERAGE ANNUAL WIND SPEED } & =7.50 \mathrm{MPH} \\ \text { AVERAGE IST QUARTER RELATIVE HUMIDITY } & =68.60 \% \\ \text { AVERAGE 2ND QUARTER RELATIVE HUMIDITY } & =43.20 \% \\ \text { AVERAGE 3RD QUARTER RELATIVE HUMIDITY } & =37.90 \% \\ \text { AVERAGE 4TH QUARTER RELATIVE HUMIDITY } & =69.40 \%\end{array}$

NOTE: PRECIPITATION DATA FOR HANFORD WASHINGTON WAS ENTERED BY THE USER.

NOTE: TEMPERATURE DATA FOR HANFORD WASHINGTON WAS ENTERED BY THE USER.

NOTE: SOLAR RADIATION DATA FOR HANFORD WASHINGTON WAS ENTERED BY THE USER.

STATION LATITUDE $=46.30$ DEGREES 


\begin{tabular}{|c|c|c|c|}
\hline \multicolumn{2}{|c|}{ ANNUAL TOTALS FOR YEAR } & 70 & \multirow[b]{2}{*}{ PERCENT } \\
\hline & INCHES & CU. FEET & \\
\hline PRECIPITATION & 6.33 & 1516542.120 & 100.00 \\
\hline RUNOFF & 0.195 & 46822.121 & 3.09 \\
\hline EVAPOTRANSPIRATION & 6.016 & 1441288.370 & 95.04 \\
\hline PERC./LEAKAGE THROUGH LAYER 1 & 1.072153 & 256866.516 & 16.94 \\
\hline CHANGE IN WATER STORAGE & -0.953 & -228434.797 & -15.06 \\
\hline SOIL WATER AT START OF YEAR & 3.696 & 885484.062 & \\
\hline SOIL WATER AT END OF YEAR & 2.743 & 657049.250 & \\
\hline SNOW WATER AT START OF YEAR & 0.000 & 0.000 & 0.00 \\
\hline SNOW WATER AT END OF YEAR & 0.000 & 0.000 & 0.00 \\
\hline ANNUAL WATER BUDGET BALANCE & 0.0000 & -0.114 & 0.00 \\
\hline \multicolumn{4}{|c|}{ 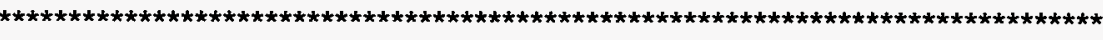 } \\
\hline \multicolumn{4}{|c|}{ 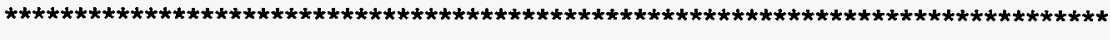 } \\
\hline \multicolumn{4}{|c|}{ ANNUAL TOTALS FOR YEAR 71} \\
\hline & INCHES & CU. FEET & PERCENT \\
\hline PRECIPITATION & 6.30 & 1509354.250 & 100.00 \\
\hline RUNOFF & 0.048 & 11399.265 & 0.76 \\
\hline EVAPOTRANSPIRATION & 5.191 & 1243665.370 & 82.40 \\
\hline PERC./LEAKAGE THROUGH LAYER 1 & 0.455787 & 109197.508 & 7.23 \\
\hline CHANGE IN WATER STORAGE & 0.606 & 145091.766 & 9.61 \\
\hline SOIL WATER AT START OF YEAR & 2.743 & 657049.250 & \\
\hline SOIL WATER AT END OF YEAR & 3.324 & 796385.250 & \\
\hline SNOW WATER AT START OF YEAR & 0.000 & 0.000 & 0.00 \\
\hline SNOW WATER AT END OF YEAR & 0.024 & 5755.759 & 0.38 \\
\hline ANNUAL WATER BUDGET BALANCE & 0.0000 & 0.364 & 0.00 \\
\hline
\end{tabular}




\begin{tabular}{|c|c|c|c|}
\hline \multicolumn{2}{|c|}{ ANNUAL TOTALS FOR YEAR } & 72 & \multirow[b]{2}{*}{ PERCENT } \\
\hline & INCHES & CU. FEET & \\
\hline PRECIPITATION & 6.39 & 1530916.500 & 100.00 \\
\hline RUNOFF & 0.002 & 387.464 & 0.03 \\
\hline EVAPOTRANSPIRATION & 5.519 & 1322183.620 & 86.37 \\
\hline PERC./LEAKAGE THROUGH LAYER 1 & 0.986325 & 236303.828 & 15.44 \\
\hline CHANGE IN WATER STORAGE & -0.117 & -27958.830 & -1.83 \\
\hline SOIL WATER AT START OF YEAR & 3.324 & 796385.250 & \\
\hline SOIL WATER AT END OF YEAR & 3.231 & 774182.187 & \\
\hline SNOW WATER AT START OF YEAR & 0.024 & 5755.759 & 0.38 \\
\hline SNOW WATER AT END OF YEAR & 0.000 & 0.000 & 0.00 \\
\hline ANNUAL WATER BUDGET BALANCE & 0.0000 & 0.400 & 0.00 \\
\hline ANNUAL TOTALS & FOR YEAR & & \\
\hline & INCHES & CU. FEET & PERCENT \\
\hline PRECIPITATION & 8.27 & 1981327.000 & 100.00 \\
\hline RUNOFF & 0.044 & 10475.886 & 0.53 \\
\hline EVAPOTRANSPIRATION & 5.479 & 1312695.620 & 66.25 \\
\hline PERC./LEAKAGE THROUGH LAYER 1 & 0.341120 & 81725.570 & 4.12 \\
\hline CHANGE IN WATER STORAGE & 2.406 & 576429.437 & 29.09 \\
\hline SOIL WATER AT START OF YEAR & 3.231 & 774182.187 & \\
\hline SOIL WATER AT END OF YEAR & 5.183 & 1241701.750 & \\
\hline SNOW WATER AT START OF YEAR & 0.000 & 0.000 & 0.00 \\
\hline SNOW WATER AT END OF YEAR & 0.455 & 108909.969 & 5.50 \\
\hline ANNUAL WATER BUDGET BALANCE & 0.0000 & 0.371 & 0.00 \\
\hline
\end{tabular}




\begin{tabular}{|c|c|c|c|}
\hline \multicolumn{4}{|c|}{ ANNUAL TOTALS FOR YEAR } \\
\hline & INCHES & CU. FEET & PERCENT \\
\hline PRECIPITATION & 5.30 & 1269774.250 & 100.00 \\
\hline RUNOFF & 0.057 & 13550.226 & 1.07 \\
\hline EVAPOTRANSPIRATION & 6.719 & 1609843.750 & 126.78 \\
\hline PERC. / LEAKAGE THROUGH LAYER 1 & 1.292625 & 309687.031 & 24.39 \\
\hline CHANGE IN WATER STORAGE & -2.769 & -663307.312 & -52.24 \\
\hline SOIL. WATER AT START OF YEAR & 5.183 & 1241701.750 & \\
\hline SOIL WATER AT END OF YEAR & 2.869 & 687304.375 & \\
\hline SNOW WATER AT START OF YEAR & 0.455 & 108909.969 & 8.58 \\
\hline SNOW WATER AT END OF YEAR & 0.000 & 0.000 & 0.00 \\
\hline ANNUAL WATER BUDGET BALANCE & 0.0000 & 0.571 & 0.00 \\
\hline \multirow{2}{*}{\multicolumn{4}{|c|}{ 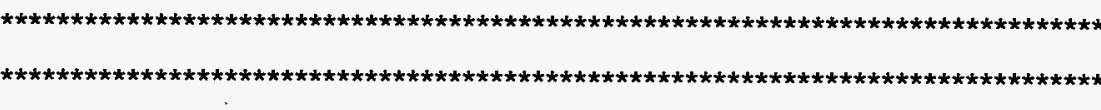 }} \\
\hline & & & \\
\hline \multicolumn{3}{|c|}{ ANNUAL TOTALS FOR YEAR 75} & \\
\hline & INCHES & CU. FEET & PERCENT \\
\hline PRECIPITATION & 7.73 & 1851953.500 & 100.00 \\
\hline RUNOFF & 0.027 & 6433.630 & 0.35 \\
\hline EVAPOTRANSPIRATION & 6.938 & 1662308.750 & 89.76 \\
\hline PERC./LEAKAGE THROUGH LAYER 1 & 0.706561 & 169277.891 & 9.14 \\
\hline CHANGE IN WATER STORAGE & 0.058 & 13933.360 & 0.75 \\
\hline SOIL WATER AT START OF YEAR & 2.869 & 687304.375 & \\
\hline SOIL WATER AT END OF YEAR & 2.927 & 701237.687 & \\
\hline SNOW WATER AT START OF YEAR & 0.000 & 0.000 & 0.00 \\
\hline SNOW WATER AT END OF YEAR & 0.000 & 0.000 & 0.00 \\
\hline ANNUAL WATER BUDGET BALANCE & 0.0000 & -0.157 & 0.00 \\
\hline
\end{tabular}




\begin{tabular}{|c|c|c|c|}
\hline ANNUAL & TOTALS FOR YEAR & 76 & \\
\hline & INCHES & CU. FEET & PERCENT \\
\hline PRECIPITATION & 2.99 & 716344.062 & 100.00 \\
\hline RUNOFF & 0.000 & 0.000 & 0.00 \\
\hline EVAPOTRANSPIRATION & 2.723 & 652342.625 & 91.07 \\
\hline PERC./LEAKAGE THROUGH LAYER 1 & 0.558068 & 133702.000 & 18.66 \\
\hline CHANGE IN WATER STORAGE & -0.291 & -69700.617 & -9.73 \\
\hline SOIL WATER AT START OF YEAR & 2.927 & 701237.687 & \\
\hline SOIL WATER AT END OF YEAR & 2.636 & 631537.062 & \\
\hline SNOW WATER AT START OF YEAR & 0.000 & 0.000 & 0.00 \\
\hline SNOW WATER AT END OF YEAR & 0.000 & 0.000 & 0.00 \\
\hline ANNUAL WATER BUDGET BALANCE & 0.0000 & 0.057 & 0.00 \\
\hline
\end{tabular}

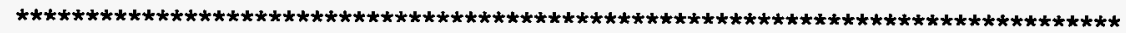

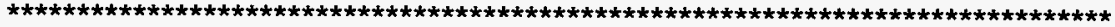
ANNUAL TOTALS FOR YEAR 77

\begin{tabular}{|c|c|c|c|}
\hline & INCHES & CU. FEET & PERCENT \\
\hline PRECIPITATION & 6.41 & 1535708.120 & 100.00 \\
\hline RUNOFF & 0.000 & 0.000 & 0.00 \\
\hline EVAPOTRANSPIRATION & 4.769 & 1142493.500 & 74.40 \\
\hline PERC./LEAKAGE THROUGH LAYER 1 & 0.418885 & 100356.477 & 6.53 \\
\hline CHANGE IN WATER STORAGE & 1.222 & 292857.312 & 19.07 \\
\hline SOIL WATER AT START OF YEAR & 2.636 & 631537.062 & \\
\hline SOIL WATER AT END OF YEAR & 3.756 & 899872.625 & \\
\hline SNOW WATER AT START OF YEAR & 0.000 & 0.000 & 0.00 \\
\hline SNOW WATER AT END OF YEAR & 0.102 & 24521.824 & 1.60 \\
\hline ANNUAL WATER BUDGET BALANCE & 0.0000 & 0.778 & 0.00 \\
\hline
\end{tabular}




$\begin{array}{lrrr} & & \\ \text { ANNUAL TOTALS FOR YEAR } & 78 & \\ & \text { INCHES } & \text { CU. FEET } & \text { PERCENT } \\ \text { PRECIPITATION } & -3.37 & 1526125.000 & 100.00 \\ \text { RUNOFF } & 0.033 & 7951.898 & 0.52 \\ \text { EVAPOTRANSPIRATION } & 6.418 & 1537506.370 & 100.75 \\ \text { PERC. /LEAKAGE THROUGH LAYER } & 1 & 229821.156 & 15.06 \\ \text { CHANGE IN WATER STORAGE } & 0.959267 & -249154.172 & -16.33 \\ \text { SOIL WATER AT START OF YEAR } & -1.040 & 899872.625 & \\ \text { SOIL WATER AT END OF YEAR } & 3.756 & 675240.250 & \\ \text { SNOW WATER AT START OF YEAR } & 2.818 & 24521.824 & 1.61 \\ \text { SNOW WATER AT END OF YEAR } & 0.102 & 0.000 & 0.00 \\ \text { ANNUAL WATER BUDGET BALANCE } & 0.000 & -0.214 & 0.00\end{array}$

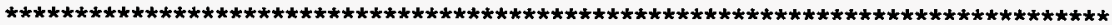

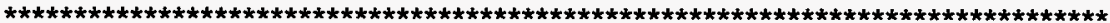
ANNUAL TOTALS FOR YEAR 79

\begin{tabular}{lrrr} 
& INCHES & CU. FEET & \multicolumn{1}{c}{ PERCENT } \\
PRECIPITATION & -56 & 1332064.870 & 100.00 \\
RUNOFF & 0.000 & 0.000 & 0.00 \\
EVAPOTRANSPIRATION & 4.562 & 1093044.500 & 82.06 \\
PERC. /LEAKAGE THROUGH LAYER & 0.271215 & 64977.703 & 4.88 \\
CHANGE IN WATER STORAGE & 0.726 & 174042.250 & 13.07 \\
SOIL WATER AT START OF YEAR & 2.818 & 675240.250 & \\
SOIL WATER AT END OF YEAR & 3.371 & 807582.000 & 0.00 \\
SNOW WATER AT START OF YEAR & 0.000 & 0.000 & 3.13 \\
SNOW WATER AT END OF YEAR & 0.174 & 41700.523 & 0.493 \\
ANNUAL WATER BUDGET BALANCE & 0.0000 & 0.00
\end{tabular}




\begin{tabular}{|c|c|c|c|}
\hline ANNUAL TOTALS & FOR YEAR & 80 & \\
\hline & INCHES & CU. FEET & PERCENT \\
\hline PRECIPITATION & 9.68 & 2319135.250 & 100.00 \\
\hline RUNOFF & 0.001 & 329.297 & 0.01 \\
\hline EVAPOTRANSPIRATION & 8.948 & 2143816.000 & 92.44 \\
\hline PERC./LEAKAGE THROUGH LAYER 1 & 0.881239 & 211127.141 & 9.10 \\
\hline CHANGE IN WATER STORAGE & -0.151 & -36138.086 & -1.56 \\
\hline SOIL WATER AT START OF YEAR & 3.371 & 807582.000 & \\
\hline SOIL WATER AT END OF YEAR & 3.394 & 813144.437 & \\
\hline SNOW WATER AT START OF YEAR & 0.174 & 41700.520 & 1.80 \\
\hline SNOW WATER AT END OF YEAR & 0.000 & 0.000 & 0.00 \\
\hline ANNUAL WATER BUDGET BALANCE & 0.0000 & 0.828 & 0.00 \\
\hline ANNUAL TOTALS & FOR YEAR & 81 & \\
\hline & INCHES & CU. FEET & PERCENT \\
\hline PRECIPITATION & 7.04 & 1686643.120 & 100.00 \\
\hline RUNOFF & 0.000 & 0.000 & 0.00 \\
\hline EVAPOTRANSPIRATION & 5.677 & 1360191.000 & 80.64 \\
\hline PERC./LEAKAGE THROUGH LAYER 1 & 0.792460 & 189857.516 & 11.26 \\
\hline CHANGE IN WATER STORAGE & 0.570 & 136594.406 & 8.10 \\
\hline SOIL WATER AT START OF YEAR & 3.394 & 813144.437 & \\
\hline SOIL WATER AT END OF YEAR & 3.953 & 946962.937 & \\
\hline SNOW WATER AT START OF YEAR & 0.000 & 0.000 & 0.00 \\
\hline SNOW WATER AT END OF YEAR & 0.012 & 2775.876 & 0.16 \\
\hline ANNUAL WATER BUDGET BALANCE & 0.0000 & 0.214 & 0.00 \\
\hline
\end{tabular}




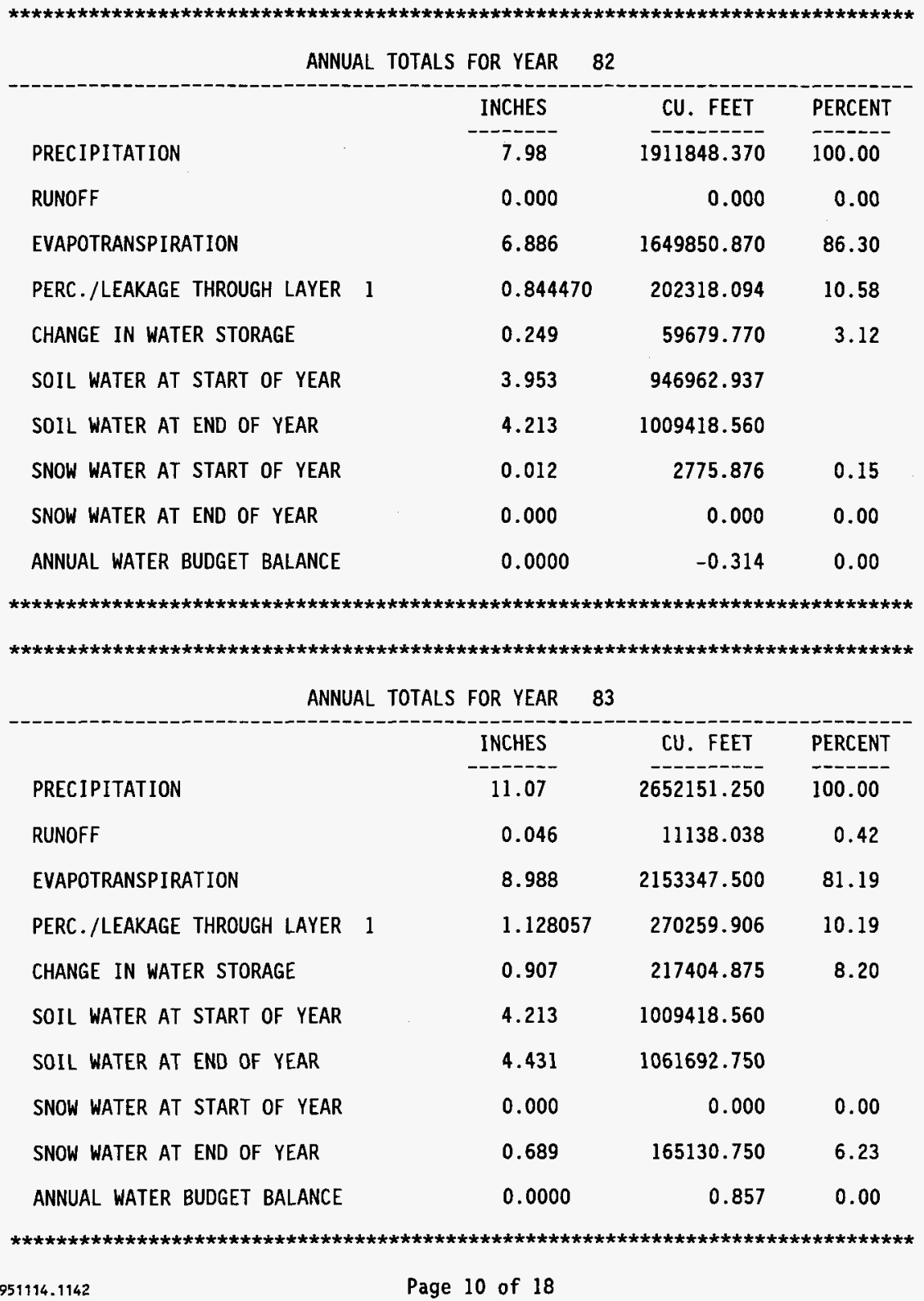




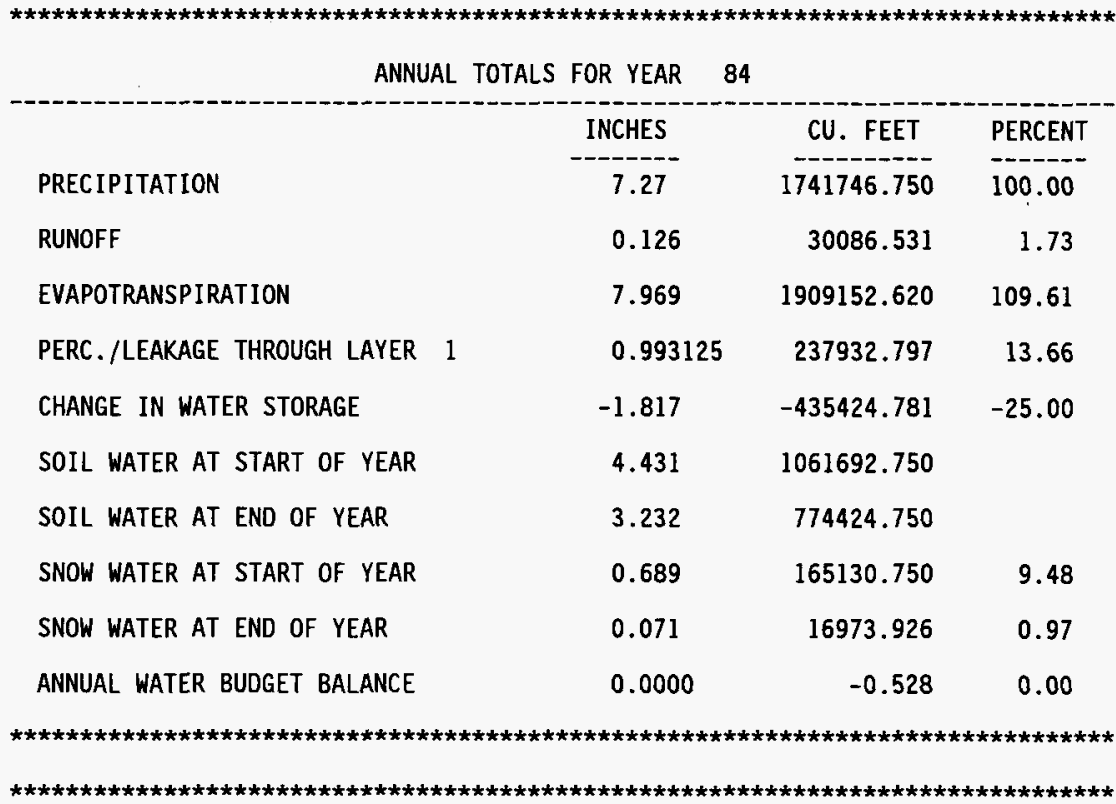

ANNUAL TOTALS FOR YEAR 85

\begin{tabular}{|c|c|c|c|}
\hline & INCHES & CU. FEET & PERCENT \\
\hline PRECIPITATION & 5.10 & 1221858.000 & 100.00 \\
\hline RUNOFF & 0.147 & 35102.988 & 2.87 \\
\hline EVAPOTRANSPIRATION & 4.471 & 1071082.000 & 87.66 \\
\hline PERC./LEAKAGE THROUGH LAYER 1 & 0.318013 & 76189.453 & 6.24 \\
\hline CHANGE IN WATER STORAGE & 0.165 & 39483.508 & 3.23 \\
\hline SOIL WATER AT START OF YEAR & 3.232 & 7.74424 .750 & \\
\hline SOIL WATER AT END OF YEAR & 3.083 & 738690.312 & \\
\hline SNOW WATER AT START OF YEAR & 0.071 & 16973.926 & 1.39 \\
\hline SNOW WATER AT END OF YEAR & 0.385 & 92191.906 & 7.55 \\
\hline ANNUAL WATER BUDGET BALANCE & 0.0000 & 0.000 & 0.00 \\
\hline
\end{tabular}




\begin{tabular}{|c|c|c|c|}
\hline \multicolumn{2}{|c|}{ ANNUAL TOTALS FOR YEAR } & 86 & \multirow[b]{2}{*}{ PERCENT } \\
\hline & INCHES & CU. FEET & \\
\hline PRECIPITATION & 7.09 & 1698622.750 & 100.00 \\
\hline RUNOFF & 0.272 & 65202.500 & 3.84 \\
\hline EVAPOTRANSPIRATION & 6.665 & 1596913.500 & 94.01 \\
\hline PERC./LEAKAGE THROUGH LAYER 1 & 0.750335 & 179765.156 & 10.58 \\
\hline CHANGE IN WATER STORAGE & -0.598 & -143259.484 & -8.43 \\
\hline SOIL WATER AT START OF YEAR & 3.083 & 738690.312 & \\
\hline SOIL WATER AT END OF YEAR & 2.870 & 687622.750 & \\
\hline SNOW WATER AT START OF YEAR & 0.385 & 92191.906 & 5.43 \\
\hline SNOW WATER AT END OF YEAR & 0.000 & 0.000 & 0.00 \\
\hline ANNUAL WATER BUDGET BALANCE & 0.0000 & 1.071 & 0.00 \\
\hline \multicolumn{4}{|c|}{ 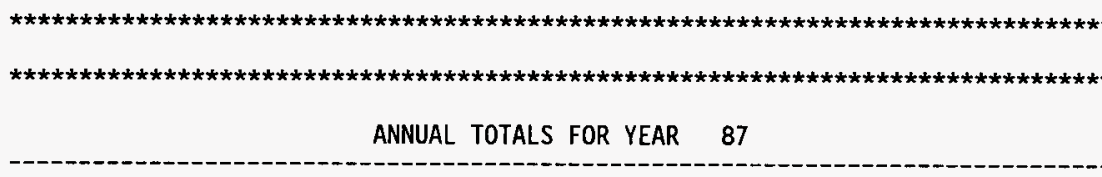 } \\
\hline & INCHES & CU. FEET & PERCENT \\
\hline PRECIPITATION & 5.07 & 1214670.370 & 100.00 \\
\hline RUNOFF & 0.000 & 0.000 & 0.00 \\
\hline EVAPOTRANSPIRATION & 3.662 & 877378.875 & 72.23 \\
\hline PERC./LEAKAGE THROUGH LAYER 1 & 0.669049 & 160290.672 & 13.20 \\
\hline CHANGE IN WATER STORAGE & 0.739 & 177000.797 & 14.57 \\
\hline SOIL WATER AT START OF YEAR & 2.870 & 687622.750 & \\
\hline SOIL WATER AT END OF YEAR & 3.609 & 864623.562 & \\
\hline SNOW WATER AT START OF YEAR & 0.000 & 0.000 & 0.00 \\
\hline SNOW WATER AT END OF YEAR & 0.000 & 0.000 & 0.00 \\
\hline ANNUAL WATER BUDGET BALANCE & 0.0000 & 0.043 & 0.00 \\
\hline
\end{tabular}




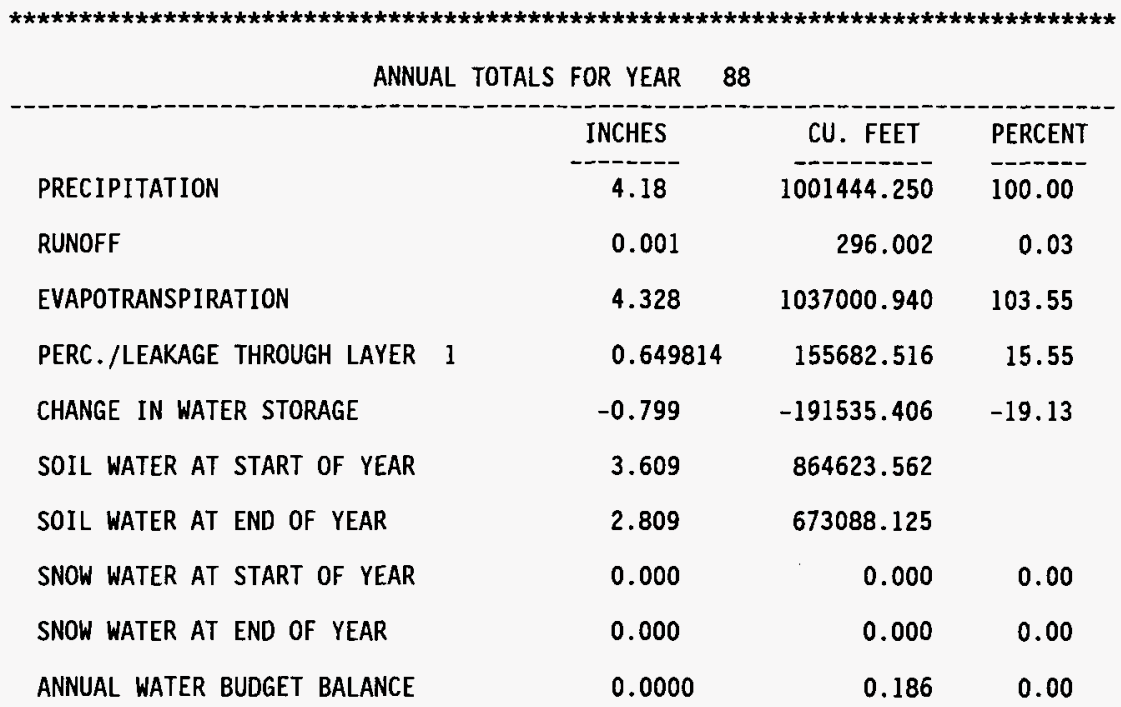

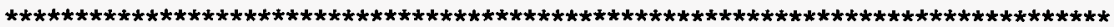

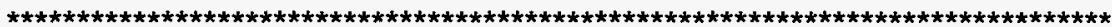
ANNUAL TOTALS FOR YEAR 89

$\begin{array}{lcrr} & \text { INCHES } & \text { CU. FEET } & \text { PERCENT } \\ \text { PRECIPITATION } & 6.92 & 1657894.120 & 100.00 \\ \text { RUNOFF } & 0.143 & 34247.230 & 2.07 \\ \text { EVAPOTRANSPIRATION } & 6.201 & 1485599.620 & 89.61 \\ \text { PERC./LEAKAGE THROUGH LAYER } & 0.616823 & 147778.375 & 8.91 \\ \text { CHANGE IN WATER STORAGE } & -0.041 & -9731.304 & -0.59 \\ \text { SOIL WATER AT START OF YEAR } & 2.809 & 673088.125 & \\ \text { SOIL WATER AT END OF YEAR } & 2.769 & 663356.812 & 0.00 \\ \text { SNOW WATER AT START OF YEAR } & 0.000 & 0.000 & 0.00 \\ \text { SNOW WATER AT END OF YEAR } & 0.000 & 0.000 & 0.00 \\ \text { ANNUAL WATER BUDGET BALANCE } & 0.0000 & 0.129 & \end{array}$




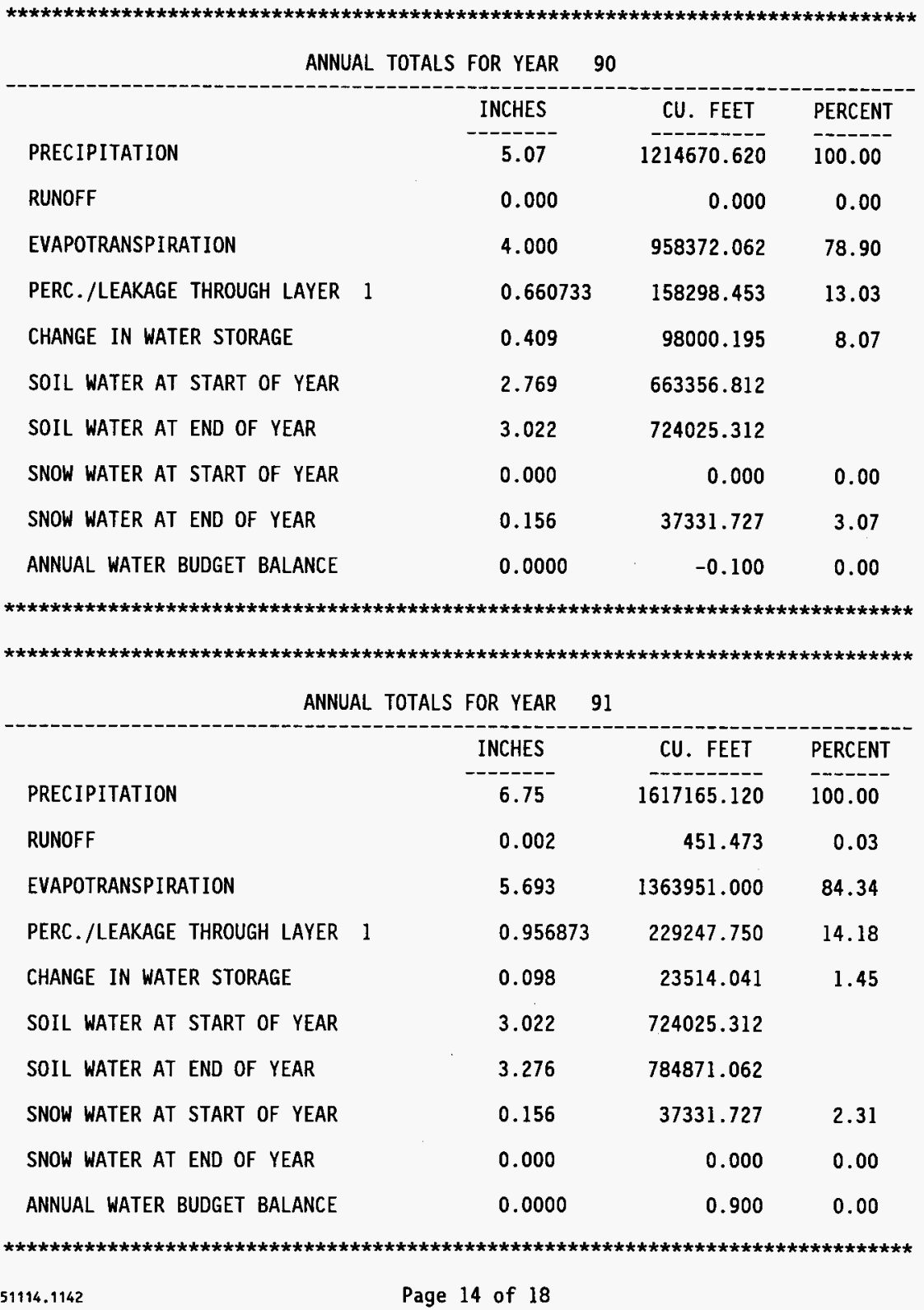


HELP, Version 3, by EPA

Output File: COVER4.OUT

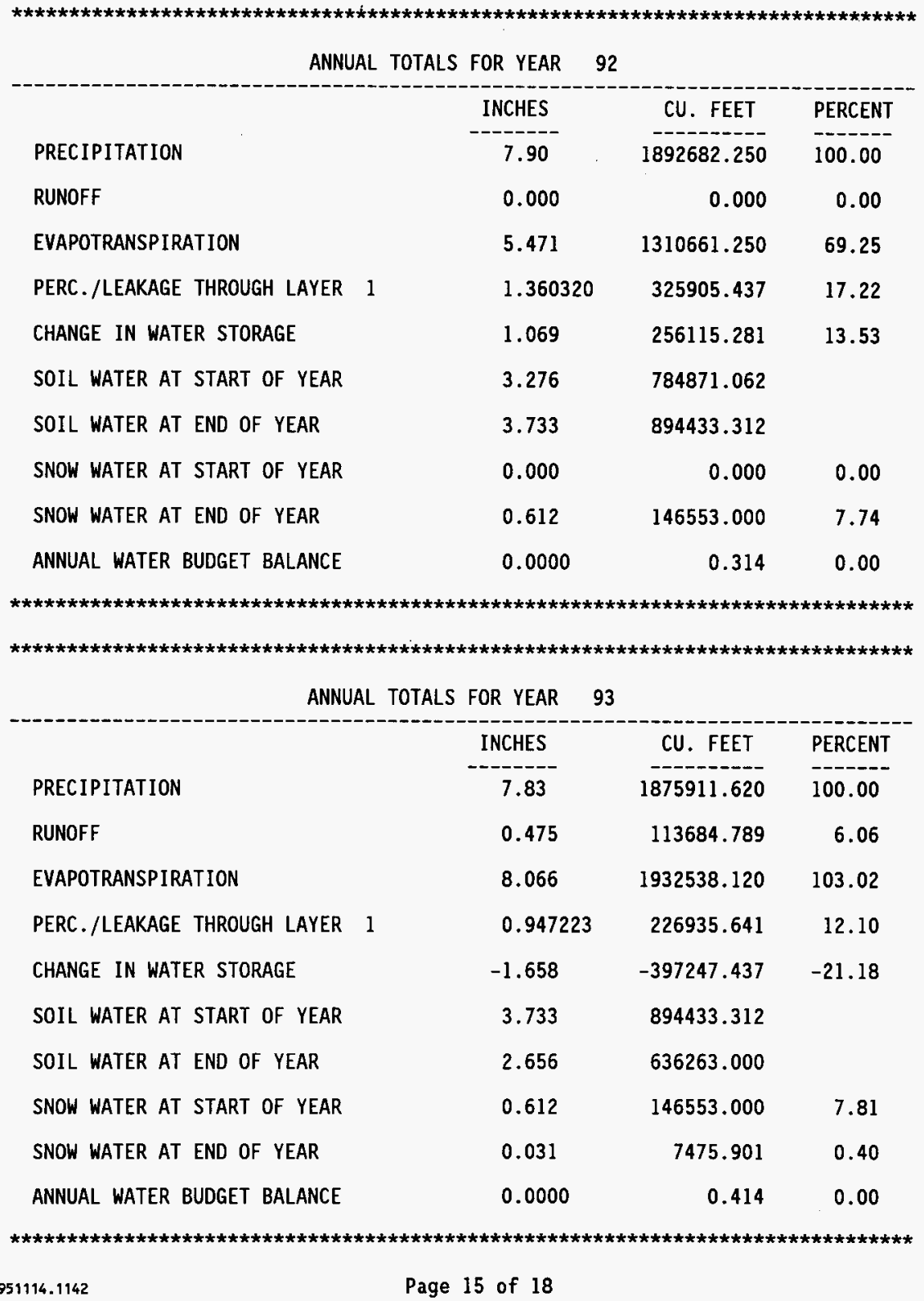




\begin{tabular}{|c|c|c|c|}
\hline \multicolumn{4}{|c|}{ ANNUAL TOTALS FOR YEAR } \\
\hline & INCHES & CU. FEET & PERCENT \\
\hline PRECIPITATION & 6.12 & 1466230.120 & 100.00 \\
\hline RUNOFF & 0.000 & 0.000 & 0.00 \\
\hline EVAPOTRANSPIRATION & 4.648 & 1113573.620 & 75.95 \\
\hline PERC./LEAKAGE THROUGH LAYER 1 & 0.434970 & 104210.227 & 7.11 \\
\hline CHANGE IN WATER STORAGE & 1.037 & 248445.812 & 16.94 \\
\hline SOIL WATER AT START OF YEAR & 2.656 & 636263.000 & \\
\hline SOIL WATER AT END OF YEAR & 3.724 & 892184.750 & \\
\hline SNOW WATER AT START OF YEAR & 0.031 & 7475.901 & 0.51 \\
\hline SNOW WATER AT END OF YEAR & 0.000 & 0.000 & 0.00 \\
\hline ANNUAL WATER BUDGET BALANCE & 0.0000 & 0.486 & 0.00 \\
\hline
\end{tabular}




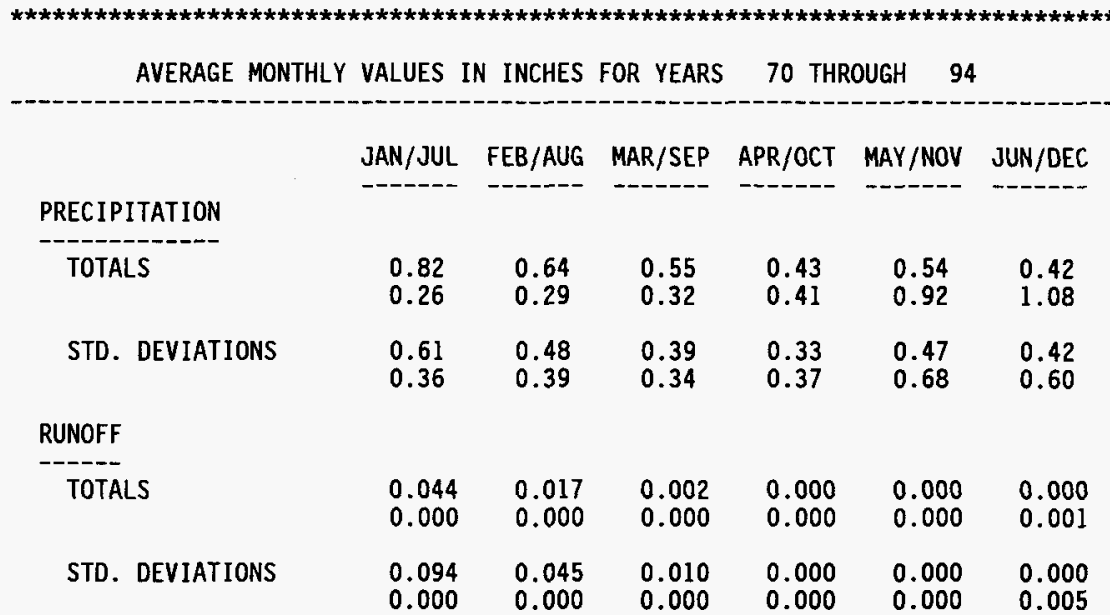

EVAPOTRANSPIRATION

TOTALS

STD. DEVIATIONS

$\begin{array}{ll}0.596 & 0.678 \\ 0.318 & 0.240\end{array}$

0.259

0.362
0.412

0.314
0.397

0.219

0.329

0.468

0.363
0.277

0.189
0.607

0.503

0.466

0.285
0.704

0.621

0.457

0.216

PERCOLATION/LEAKAGE THROUGH LAYER 1

$\begin{array}{lllllll}\text { TOTALS } & 0.0490 & 0.0379 & 0.0496 & 0.0694 & 0.0727 & 0.1117 \\ & 0.1162 & 0.0831 & 0.0523 & 0.0488 & 0.0372 & 0.0346 \\ \text { STD. DEVIATIONS } & 0.0365 & 0.0351 & 0.0739 & 0.0625 & 0.0487 & 0.0834 \\ & 0.0601 & 0.0264 & 0.0156 & 0.0128 & 0.0090 & 0.0169\end{array}$


HELP, Version 3, by EPA

Output File: COVER4.OUT

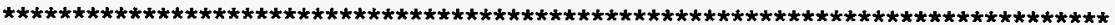

AVERAGE ANNUAL TOTALS \& (STD. DEVIATIONS) FOR YEARS 70 THROUGH 94

\begin{tabular}{lccccc} 
& \multicolumn{2}{c}{ INCHES } & CU. FEET & \multicolumn{1}{c}{ PERCENT } \\
PRECIPITATION & 6.67 & $(1.691)$ & 1597711.2 & 100.00 \\
RUNOFF & 0.065 & $(0.1121)$ & 15502.37 & 0.970 \\
EVAPOTRANSPIRATION & 5.840 & $(1.5858)$ & 1399232.12 & 87.577 \\
$\begin{array}{l}\text { PERCOLATION/LEAKAGE THROUGH } \\
\text { FROM LAYER 1 }\end{array}$ & $0.76262(0.29844)$ & 182708.594 & 11.43565 \\
$\begin{array}{l}\text { CHANGE IN WATER STORAGE } \\
-0.001\end{array}$ & $(1.1028)$ & 268.03 & 0.017
\end{tabular}

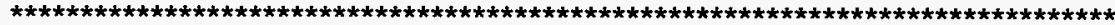

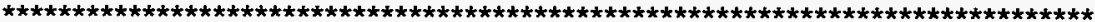

PEAK DAILY VALUES FOR YEARS 70 THROUGH 94

\begin{tabular}{|c|c|c|}
\hline & (INCHES) & (CU. FT.) \\
\hline PRECIPITATION & 0.93 & 222809.406 \\
\hline RUNOFF & 0.425 & 101752.1170 \\
\hline PERCOLATION/LEAKAGE THROUGH LAYER & 0.037927 & 9086.53613 \\
\hline SNOW WATER & 1.22 & 292734.3750 \\
\hline
\end{tabular}

MAXIMUM VEG. SOIL WATER (VOL/VOL) 0.1303

MINIMUM VEG. SOIL WATER (VOL/VOL) $\mathbf{0 . 0 2 0 4}$

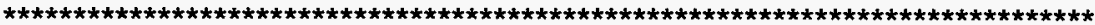

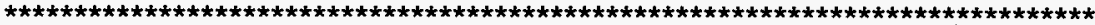

FINAL WATER STORAGE AT END OF YEAR 94

$\begin{array}{ccc}\text { LAYER } & \text { (INCHES) } & \text { (VOL/VOL) } \\ -1 & 3.7244 & 0.0776\end{array}$

SNOW WATER $\quad 0.000$

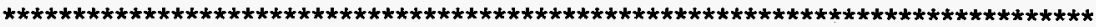

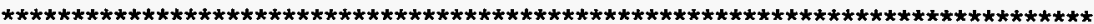


DOE/RL-90-38, Rev. 1

4 Number of copies

5

6

7

8

OFFSITE

2

1

1

1

\section{DISTRIBUTION}

Washington State Department of Ecology

Nuclear Waste Program

1315 West 4th

Kennewick, Washington 99336-6018

M. N. Jaraysi

F. Ma

Washington State Department of Ecology

South Sound Center

99 South Sound

Lacey, Washington 98503

Ecology Library

Confederated Tribes and Bands

of the Yakama Indian Nation

P.O. Box 151

Toppenish, Washington 98948

Mr. Russell Jim, Tribal Council

Nez Perce Indian Tribe

P.O. Box 365

Lapwai, Idaho 83540-0365

Ms. Donna Powaukee, NPTEC

Confederated Tribes of the

Umatilla Indian Reservation

P.O. Box 638

Pendleton, Oregon 97801

Mr. J. R. Wilkinson 


\begin{tabular}{|c|c|c|c|}
\hline 1 & ONSITE & & \\
\hline 3 & 5 & U. S. Department of Energy. & \\
\hline 4 & & Richland Operations Office & \\
\hline 5 & & & \\
\hline 6 & & E. M. Mattlin & A5-15 \\
\hline 7 & & D. J. Ortiz & A2 -45 \\
\hline 8 & & J. E. Rasmussen & A5-15 \\
\hline 9 & & DOE-RL Reading Room (2) & $\mathrm{H} 2-53$ \\
\hline 10 & & & \\
\hline 11 & 4 & ICF Kaiser Hanford Company & \\
\hline 12 & & & \\
\hline 13 & & C. M. Conselman & G3-06 \\
\hline 14 & & S. D. Consort & S3-09 \\
\hline 15 & & K. D. Johnson (2) & G4-07 \\
\hline 16 & & & \\
\hline $\begin{array}{l}17 \\
18\end{array}$ & 6 & Westinghouse Hanford Company & \\
\hline 19 & & R. C. Bowman & H6-24 \\
\hline 20 & & J. C. Sonnichsen & H6-24 \\
\hline 21 & & RCRA File & H6-23 \\
\hline 22 & & WHC EDMC & H6-08 \\
\hline 23 & & Document Processing Center & A3-94 \\
\hline 24 & & WHC Central Files & A3-88 \\
\hline 25 & & & \\
\hline
\end{tabular}

